ANTIBODY FORMATION

IN

MOUSE BONE MARROW 



\section{ANTIBODY FORMATION}

\section{IN}

\section{MOUSE BONE MARROW}

\section{PROEFSCHRIFT}

ter verkrijging van de graad van doctor in de geneeskunde aan de Erasmus Universiteit te Rotterdam, op gezag van de Rector Magnificus Prof. dr. B. Leijnse en volgens besluit van het college van dekanen.

De openbare verdediging zal plaats vinden op woensdag 15 oktober 1975 , des namiddags te 16.15 uur

door

\section{ROBBERT BENNER}

geboren te Rotterdam in 1948

\section{5}

Drukkerij Pasmans, Den Haag 


$$
\begin{aligned}
& \text { Promotor : Prof. dr. O. Vos } \\
& \text { Co-referenten: Prof. dr. D.W. van Bekkum } \\
& \text { Dr. W. Hijmans }
\end{aligned}
$$

Dit proefschrift werd bewerkt binnen de vakgroep Celbiologie en Genetica van de Erasmus Universiteit te Rotterdam.

Het onderzoek werd mede mogelijk gemaakt door financiële steun van de Stichting voor Medisch Wetenschappelijk Onderzoek (FUNGO). 
aan Diet 


\section{ABBREVIATIONS}

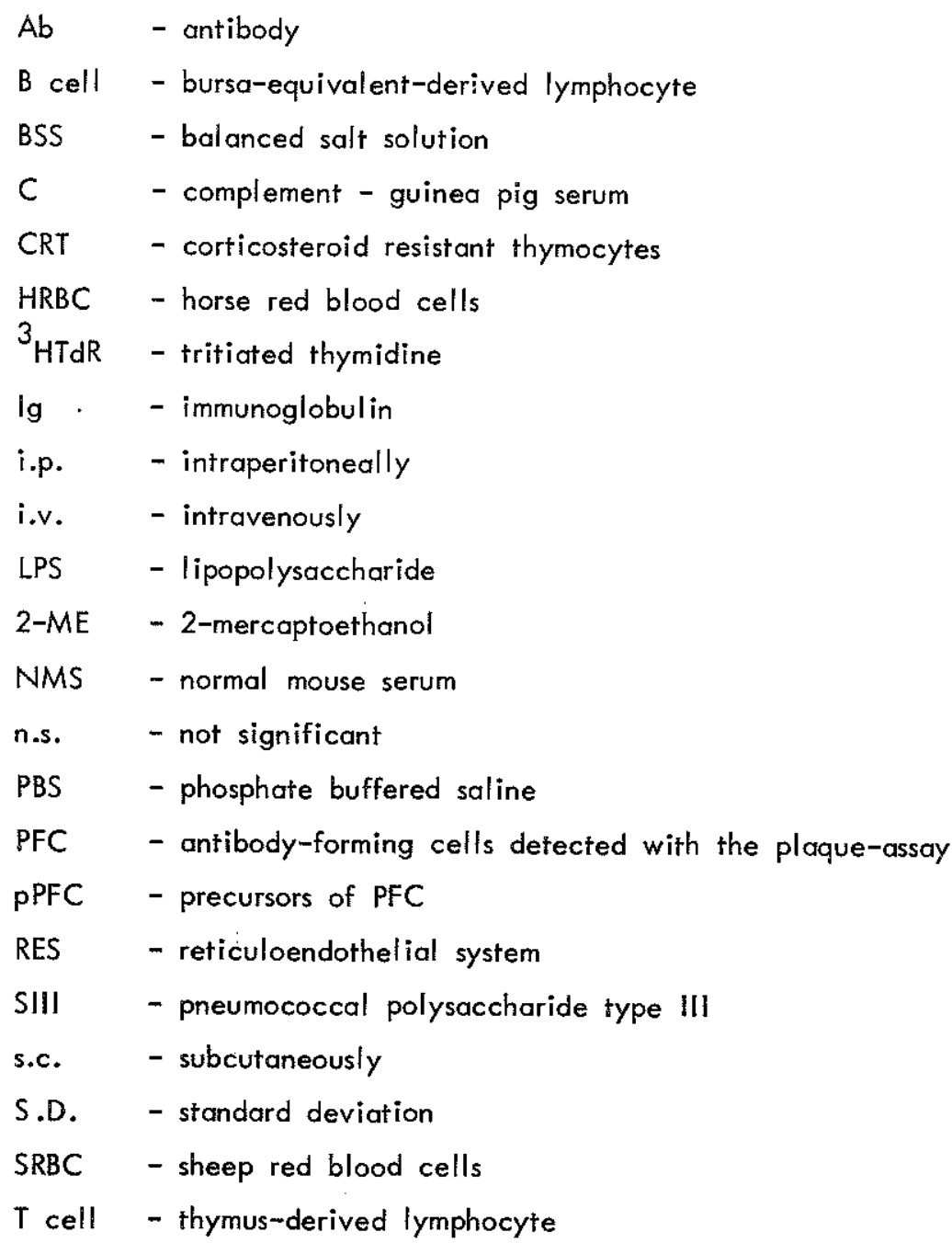


CONTENTS

INTRODUCTION 9

$\begin{array}{ll}\text { DISCUSSION } & 14\end{array}$

$\begin{array}{ll}\text { SUMMARY } & 21\end{array}$

$\begin{array}{ll}\text { SAMENVATTING } & 26\end{array}$

$\begin{array}{ll}\text { REFERENCES } & 31\end{array}$

DANKWOORD $\quad 42$

CURRICULUMM VITAE 44

APPENDIX: PUBLICATIONS I - V

\section{PUBLICATION 1}

R. Benner, F. Meima, G.M. van der Meulen and W.B. van Muiswinkel Antibody formation in mouse bone marrow. I. Evidence for the development of plaque-forming cells in situ

Immunology $26,247-255,1 \overline{1974}$

\section{PUBLICATION II}

R. Benner, F. Meima and G.M. van der Meulen Antibody formation in mouse bone marrow. II. Evidence for a memorydependent phenomenon

Cellular Immunology 13, 95-106, 1974 



\section{PUBLICATION III}

R. Benner, F. Meima, G.M. van der Meulen and W. van Ewijk

Antibody formation in mouse bone marrow. III. Effects of route of priming and antigen dose

Immunology 27, 747-760, 1974

\section{PUBLICATION IV}

R. Benner and A. van Oudenaren

Antibody formation in mouse bone marrow. IV. The influence of splenectomy on the bone marrow plaque-forming cell response to sheep red blood cells Cellular Immunology 19, 167-182, 1975

\section{PUBLICATION V}

R. Benner and A. van Oudenaren

Antibody formation in mouse bone marrow. $V$. The response to the thymusindependent antigen Escherichia coli lipopolysaccharide

Immunology, in press 



\section{INTRODUCTION}

Lymphoid organs are generally subdivided into two groups according to their contribution to antibody formation: 'primary' and 'secondary' lymphoid organs. In mammals bone marrow and thymus are considered to be 'primary' because these organs are involved in the generation of lymphocytes: B cells and $T$ cells respectively. These lymphocyres can leave their place of origin and provide for antibody formation in secondary lymphoid organs: spleen, lymph nodes, Peyer's patches and other gut-associated lymphoid ti ssue.

Affer antigenic stimulation $B$ cells can potentially differentiate into antibody producing plasma cells. T cells play a principal role in cell-mediated immune responses, which include delayed hypersensitivity, contact sensitivity, graft rejection, graft-versus-host responses and acquired resistance to some microbes. In addition to be involved in cell-mediated immunity $T$ cells cooperate with $B$ cells in antibody formation to most antigens. Thereby $T$ cells can enhance and suppress the response of the $B$ cells to the antigen. Antigens which require cooperation of $B$ cells and $T$ cells to evoke antibody formation are called 'thymus-dependent' antigens in contrast to 'thymus-independent' antigens which do not require $T$ cells for antibody formation.

There are suggestions in the literature that antibody formation in mammals can take place not only in secondary lymphoid organs but also in bone marrow:

(1) extracts of bone marrow from immunized guinea pigs and rabbits contained antibodies $(1-10)$,

(2) bone marrow cells cultivated in vitro produced (6-21) and released $(9,11,13,14,17-25)$ antibodies $(6-14,17,18,20,22-24)$ and immunoglobulins $(7,12-16,19-21,25)$,

(3) studies in rabbits $(26-29)$ and in man $(30,31)$ provided evidence for a positive correlation between the plasma cell content of the bone marrow and the serum titre after intensive antigenic stimulation, 
(4) the bone marrow of immunized rabbits and mole rats contained antibodyforming cells as determined with the plaque-assay (32-35),

(5) in man a striking similarity was found between the percentage distribution of cells of the lymphoid series in the bone marrow which are positive for the various heavy and light chains and the percentage distribution of the heavy and light chains in the serum (36-42).

Some of these studies go as far as to suggest that bone marrow is the major source of serum antibodies $(13,33,35)$ and immunoglobulins $(13,25,36-43)$.

Antibody formation by bone marrow cells of the mouse has been studied exclusively by means of the plaque-assay. Only small numbers of antibody forming cells (PFC) have been found in the bone marrow of immunized mice (44-54). In some studies $(44,45,47,49,51)$ a small but significant IgM-, IgG- and IgA-PFC response could be demonstrated some weeks after a single injection of antigen. Antibody formation in mouse bone marrow has also been studied during the secondary $(44,54)$ and tertiary (48) response. After multiple injections of the antigen small numbers of PFC in the bone marrow also appeared during the early phase of the response.

The above studies with mice by no means suggest a substantial contribution of the bone marrow to total antibody synthesis. In view of these conflicting results as compared with studies on bone marrow of other species, we felt it worthwhile to reinvestigate the mouse bone marrow as a source of antibodyforming cells. After having established that the bone marrow of mice can show a clear PFC activity after two intravenous (i.v.) injections of sheep red blood cells (SRBC), we started to investigate the underlying mechanism. In this thesis quantitative data on antibody formation in mouse bone marrow and its underlying mechanism will be presented.

\section{INTRODUCTION TO THE PAPERS}

The literature suggests migration of antibody-forming cells from secondary lymphoid organs into the bone marrow to be the underlying cause for anti- 
body formation in this organ $(10,18,21,35,38,43,45)$. Research into the mechanism which accounts for antibody formation in the bone marrow is facilitated when only a small number of organs is involved in the antibody response. After i.v. injection of mice with moderate doses of antigen, lymph nodes and gut-associated lymphoid tissue do not generate antibody forming cells. Therefore in our studies on antibody formation in mouse bone marrow the antigen was injected almost exclusively i.v.

In the graphs PFC activity in various lymphoid organs is given as the number of PFC per organ. This enables comparison of the contribution of the different lymphoid organs to the total PFC activity of the animal. Bone marrow PFC activity was determined in the femoral marrow. The PFC activity of the femoral bone marrow appeared to be representative for the PFC activity of the total marrow since the proportional PFC responses evoked by bone marrow cells from femur, tibia, humerus, sternum and rib did not differ significantly (appendix publications IV and V). For our calculations of the total bone marrow PFC activity we made use of the results of Chervenick and coworkers (55). In a detailed study these authors demonstrated with ${ }^{59} \mathrm{Fe}$-labelling that one femur of a mouse contains 5.9 per cent of its marrow. Using the same method other investigators found percentages of 6 (56) and 7 (57), which agree very well with Chervenick's data. Although the distribution of ${ }^{59} \mathrm{Fe}$ is not necessarily representative for the distribution of PFC, it gives an approximation of the total amount of bone marrow.

In appendix publication I experiments are described which show that mouse bone marrow can contain a substantial number of $\lg M-, \lg G$ - and $\lg A$-producing PFC after immunization with SRBC. This result was not found before the second i.v. injection of the antigen. During the first phase of the secondary response the spleen contained the majority of the total number of PFC. In the course of the reaction, however, the bone marrow became the major source of PFC. In this paper evidence is presented that the PFC activity in the bone marrow is caused by differentiation of non-antibody-producing cells into PFC 
with in the bone marrow in sifu.

The presence of a clear anti-SRBC PFC response in mouse bone marrow during the secondary response might be related to the generation of memory cells after the first injection of the antigen. In appendix publication II this possibility is investigated by means of cell transfer experiments. The results show that after a single i.v. injection of SRBC, specific B- and T-memory cells appear in the bone marrow. Thus the capacity of mouse bone marrow ro show PFC activity during the secondary response to SRBC coincides with the presence of $\mathrm{B}$ - and T-memory cells within this organ at the moment of the second antigen injection. It is suggested in this paper that after a second

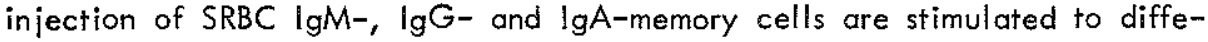
rentiate with the help of T-memory cells within the bone marrow into $\lg M-$, $\lg G-$ and $\lg A-P F C$ respectively.

In appendix publication III the influence of the route of priming and dose of SRBC on the secondary bone marrow PFC activity was studied. It was found that priming via other routes than i.v. could also provide for secondary bone marrow PFC activity after an i.v. booster dose, because after intraperitoneal or subcutaneous priming bone marrow PFC occurred as well during the secondary response.

From the data presented in appendix publication I it cannot be excluded that PFC activity in the bone marrow during the secondary response is a rather extraordinary phenomenon, attributable to the high doses of SRBC used in these studies. Appendix publication III shows data which indicate that the threshold booster dose of SRBC for spleen and bone marrow is about the same. This suggests that antibody formation to SRBC in mouse bone marrow during the secondary response is a regular phenomenon.

Appendix publication IV deals with the influence of splenectomy on the bone marrow PFC response to SRBC. Splenectomy before priming with an opti- 
mum dose of $10^{7}$ SRBC i.v. completely prevented bone marrow PFC activity during the secondary response. Cell transfer experiments revealed that splenectomy before priming with $10^{7} \mathrm{SRBC}$ i.v. also prevented the appearance of $\mathrm{B}-$ and $T$-memory cells in the bone marrow. This influence of splenectomy on both the appearance of B- and T-memory cells and the secondary bone marrow PFC activity could be partly overcome by priming with a higher antigen dose of $4 \times 10^{8}$ SRBC i.v. These results provide evidence that antibody formation in mouse bone marrow is dependent on the presence of memory cells. Secondary lymphoid organs are probably essential in order to generate these memory cells.

Thorbecke et al. (17) reported that the thymus-independent (58) antigen Brucella, in contrast to thymus-dependent antigens (10, 17), can evoke antibody formation in rabbit bone marrow during the primary response. Therefore we decided to study antibody formation in the bone marrow of the mouse in response to a thymus-independent antigen. In appendix publication $V$ antibody formation in mouse bone marrow was studied during the primary and secondary response to the thymus-independent antigen Escherichia coli lipopolysaccharide (LPS). In contrast to SRBC, antibody formation in the marrow to LPS appeared to occur not only during the secondary response but also during the primary response.

The data presented in the appendix are reviewed in the next chapter. Three possible mechanisms for antibody formation in mouse bone marrow are suggested and briefly discussed. 


\section{DISCUSSION}

A simple method to demonstrate antibody-producing cells is the plaque-assay. In this assay cells secreting specific antibodies can be quantified easily (52). Using the plaque-assay we found that mouse bone marrow can contain large numbers of antibody-forming cells after i.v. immunization with the thymusdependent antigen SRBC (appendix publications I, III, IV) and the thymusindependent antigen E. coli LPS (appendix publication V). We could demonstrate IgM- as well as IgG- and IgA-producing PFC in the marrow. Recently Kind and Malloy (59) reported the production of IgE-antibodies by adoptively transferred mouse bone marrow cells. Apparently mouse bone marrow can act not only as a primary but also as a secondary lymphoid organ.

Some studies on antibody formation $(13,33,35)$ and immunoglobulin synthesis $(13,25,36-43)$ by bone marrow cells from guinea pig (13), mole rat (33), rabbit (35) and man $(25,36-43)$ suggest that the marrow might be a major source of antibodies. Our experiments on the bone marrow PFC response after i.v. immunization of mice with SRBC and LPS provide evidence supporting this supposition. During the second phase of the secondary response to SRBC (appendix publications I, III and IV) and the response to high doses of LPS (appendix publication $V$ ) we found up to ten times as many PFC in the marrow as in all the other lymphoid organs together. In considering these results it should be kept in mind that in our studies the last antigen-injection before studying the bone marrow PFC response was always given $i . v$. The contribution of the bone marrow to the total PFC activity after other routes of antigenadministration remains to be determined.

Recently Blijham (35) studied the PFC activity of various lymphoid organs of the rabbit during the primary and secondary response to SRBC. During the second phase of both the primary and secondary response he found more PFC in the bone marrow than in all other lymphoid organs together. Primary and secondary 
PFC activity of the rabbit marrow were found to be at least partly dependent on other lymphoid organs: splenectomy before the first i.v. antigen-administration diminished the bone marrow PFC response, thereby suggesting that the PFC activity in the rabbit marrow was caused by migration of antigen-activated, possibly antibody-producing, cells into the bone marrow (35).

It is worth noting that in both Blijham's studies with rabbits and our studies with mice the spleen was found to be the site where PFC appeared at first and the bone marrow appeared to be the organ which contained by far the greatest number of PFC during the second phase of the response. This suggests that these organs have a different task during the immune response after i.v. immunization. The spleen provides for the first attack on the invading antigens, and the bone marrow takes care of the greater part of the long term production of protecting antibodies, thereby enabling the spleen to prepare for new antigenic experiences. The high bone marrow PFC activity and the decreased number of PFC in the spleen during the second phase of the response are probably due to regulating factors in these organs. Recently it was reported that bone marrow cells can synthesize a humoral factor which enhances the PFC response in cultures of lymph node cells obtained from immune donors at the peak of the productive phase of antibody formation (60). This factor might account for the high PFC activity observed in the bone marrow. On the other hand, the spleen of immunized mice was found to contain a factor which could effectively suppress the in vitro PFC response of spleen cells $(61,62)$. This factor might provide for the decrease of the splenic PFC activity during the second phase of the response.

The other primary lymphoid organ, the thymus, also showed PFC activity after i.v. immunization with SRBC (appendix publication III) and LPS (appendix publication V). PFC activity in response to both antigens was found only during the secondary response and after a high booster dose of antigen. In contrast to the bone marrow the thymus contributed only marginally to the total PFC activity in the mouse.

The results presented in the appendix of this thesis do not completely clarify 
the mechanism underlying antibody formation in mouse bone marrow. Insight into this mechanism is especially hampered by our observation that different antigens evoke a bone marrow PFC response under different conditions. So far we have only tested one large-particulate thymus-dependent antigen with various antigenic determinants (SRBC) and one small-particulate (63) thymusindependent polymeric antigen (LPS). Based upon the results obtained after immunization with these antigens, three possible mechanisms for antibody formation in mouse bone marrow are suggested and briefly discussed.

1. Antibody formation in mouse bone marrow is dependent on migration of antibody-forming cells from lymphoid organs such as spleen and lymph nodes into the bone marrow.

This possibility has been suggested in the literature $(10,18,21,35,38,43$, 45) and is consistent with the following observations: (1) during the immune response cells which produce antibodies during in vitro cultivation appeared later in bone marrow than in spleen (9); (2) immunoglobulin-containing cells $(42,43,64,65)$ and PFC $(32,54,66)$ are found in blood and lymph; (3) after bone marrow and thymus transplantation in a boy with severe combined immunodeficiency desease increased numbers of cells showing cytoplasmic immunoglobulins appeared in the peripheral blood before a rise of immunoglobulin-containing cells could be found in the bone marrow (65); (4) during ontogeny of mice immunoglobulin-containing cells were found to appear in spleen before they could be demonstrated in the bone marrow (67); (5) splenectomy before i.v. immunization with SRBC diminished the PFC activity in the bone marrow of rabbits (35); and (6) after immunization of mice with ovalbumin (59), SRBC (appendix publications I, III and IV) and LPS (appendix publication V) the appearance of antibody-forming cells in the bone marrow was delayed compared with the spleen.

2.Antibody formation in mouse bone marrow is dependent on initiation of an antibody-forming cell response by an antigen within the bone 
marrow.

This hypothesis, which has been our working hypothesis throughout the experiments, implies that the presence within the bone marrow of the lymphocytes involved in this antibody-forming cell reponse is a prerequisite. B cells specific for a variety of antigens (68), including LPS (appendix publication V), are present in normal mouse bone marrow. T cells, on the other hand, are scarce in this organ $(68,69)$. Therefore this second mechanism is consistent with our observation that during the primary response mouse bone marrow can exhibit PFC activity to the thymus-independent antigen LPS (appendix publication V), whereas it did not contain a substantial number of PFC after a single injection of the thymus-dependent antigen SRBC (appendix publications I and IV).

Due to scarcity of $T$ cells in mouse bone marrow, cells from this organ can barely evoke antibody formation to thymus-dependent antigens in lethally irradiated recipients $(68,70-79)$. After immunization increased numbers of antigenspecific B cells appear in the bone marrow (80). Marrow cells from animals previously immunized with a thymus-dependent antigen, do produce antibodies in irradiated recipients, when these cells are transferred together with the priming antigen (70-73, 78). This observation suggests that after immunization not only increased numbers of $B$ cells, but also $T$ cells appear in the marrow. We confirmed these studies using SRBC as an antigen (appendix publications II and IV). In addition we showed that both $\mathrm{B}$ - and T-memory cells in the bone marrow are antigen-specific (appendix publication II). The presence of SRBC-specific Band T-memory cells in mouse bone marrow coincided with the capacity of this organ to show PFC activity after a booster injection of SRBC (appendix publications II and IV). Moreover we found a positive correlation between the number of $\mathrm{B}$ - and T-memory cells in the bone marrow and the height of the secondary bone marrow PFC response (appendix publication IV). Therefore the second mechanism for antibody formation in mouse bone marrow is consistent with the appearance of a distinct anti-SRBC response in the marrow only after a booster injection of SRBC. 
3.Antibody formation in mouse bone marrow is dependent on migration of non-antibody-forming cells from lymphoid organs such as spleen and lymph nodes into the bone marrow during the response.

The migrating lymphocytes are stimulated by antigen outside the bone marrow, but differentiation and maturation into antibodyforming cells occur within the marrow.

This third mechanism, which is a variant of the first one, has been suggested by Langevoort et al. (10). It is consistent with: (1) the appearance of immunoglobulin-containing cells in the spleen before they could be demonstrated in the bone marrow during ontogeny (67); (2) the impaired PFC activity in the bone marrow of rabbits which were splenectomized before i.v. antigen-administration (35); and (3) the delayed appearance of antibody-forming cells in the bone marrow as compared with the spleen $(9,35,59$, appendix publications $I$ and $|I|-V)$. The appearance of a distinct anti-SRBC PFC response in mouse bone marrow only after multiple injections of SRBC (appendix publications I, III and IV) is difficult to explain with this mechanism. Possibly T-memory cells in the bone marrow are required for the further differentiation of the incoming antigen-activated cells.

The results presented in the appendix publications of this thesis are at variance with the first mechanism suggested. In our experiments anti-SRBC (appendix publications $I$ and IV) and anti-LPS (Benner and van Oudenaren, to be published) bone marrow PFC responses could occur in the absence of PFC in all other lymphoid organs. Therefore migration of antibody-forming cells into the bone marrow as the underlying cause for bone marrow PFC activity appears not to be essential. This is consistent with studies on the migration of lymphoid cells in parabiotic mice. Röpke and Everett (81) studied the migration of cells by giving ${ }^{3} \mathrm{H}$-thymidine injections to only one member of a pair and preventing escape of the radioactive isotope to the other member. They found only very few labeled immunoblasts and mature plasma cells in the bone marrow of the non-injected members as compared with the injected members.

While the first possibility that antibody-forming cells migrate into the bone 
marrow has been proven to be improbable, our experiments do suggest migration of cells to be essential for antibody formation in mouse bone marrow, at least in response to the thymus-dependent antigen SRBC (appendix publication IV). Our experiments do not allow us to select definitely between the second and third mechanism as the underlying cause for antibody formation in mouse bone marrow. Our observations that mouse bone marrow can contain large numbers of anti-SRBC (appendix publications $I$ and IV) and anti-LPS (Benner and van Oudenaren, to be published) PFC while all other lymphoid organs do not show any significant PFC activity argue against the third mechanism. One can hardly imagine that large numbers of lymphocytes are stimulated to differentiate into antibody-forming cells outside the bone marrow without providing for any PFC response at these sites. The experiments of Röpke and Everett (81) mentioned above also do not favour the third mechanism. Therefore in forthcoming experiments to elucidate the underlying cause for antibody formation in mouse bone marrow the second mechanism will remain our working hypothesis.

Supposing the second mechanism indeed is the underlying cause for antibody formation in mouse bone marrow, the question arises as to whether there is a fundamental difference between the anti-LPS and anti-SRBC PFC response in mouse bone marrow regarding the type of lymphocytes involved, virgin cells or memory cells. While the results of splenectomy experiments clearly suggest the bone marrow anti-SRBC PFC response to be dependent on memory cells, one can ask oneself whether virgin B cells can provide for the anti-LPS PFC response in the marrow. This touches directly upon the origin of the immunom competent $B$ cells in the bone marrow. Osmond and Nossal recently showed the mouse bone marrow to be involved in the generation of virgin $B$ cells (82). These authors studied the appearance of surface-immunoglobulins $(\mathrm{lg})$ on shortlived lymphocytes generated in the marrow. They provided strong evidence that small lymphocytes in the marrow are initially lg-negative but rapidly express increasing amounts of surface-lg during differentiation and proliferation. Basten and coworkers using a radioactively labeled antigen 'suicide' technique have shown that, in conditions in which thymocytes and spleen B cells are 
inactivated, bone marrow lymphocytes are unaffected (83). This could be interpreted as suggesting that maturation to the antigen-binding stage takes place outside, and not within the bone marrow. Everett and Caffrey indeed provided evidence for a continuous transport of recently generated small lymphocytes from the bone marrow to the spleen (84). Therefore it is a real possibility that all immunocompetent $B$ cells in mouse bone marrow, including the $B$ cells specific for LPS, are immigrated long-lived memory cells for environmental antigens stimulating the lymphoid system. Autoradiographic studies are consistent with this supposition, since in mice essentially no short-lived lymphocytes migrate into the bone marrow $(81,85)$, while long-lived B lymphocytes normally do so $(81,86)$. This line of evidence led us to conclude that there is not necessarily a fundamental difference between the anti-LPS and anti-SRBC PFC response in mouse bone marrow. 
Lymphoid organs are generally subdivided into two groups according to their contribution to antibody formation: 'primary' and 'secondary' lymphoid organs. In mammals bone marrow and thymus are considered to be 'primary' because these organs are involved in the generation of lymphocytes: B cells and $T$ cells respectively. These lymphocytes can leave their place of origin and provide for antibody formation in secondary lymphoid organs: spleen, lymph nodes, Peyer's patches and other gut-associated lymphoid tissue.

For rabbit, guinea pig and mole rat it has been shown that antibody formation can occur not only in secondary lymphoid organs but also in the bone marrow. The plaque-assay, which is a direct assay to demonstrate the presence of antibody-forming cells, has been very little applied to the bone marrow. As far as this assay has been used to demonstrate antibody-forming cells in the bone marrow, its use has been limited almost exclusively to the bone marrow of the mouse. Using this assay only small numbers of antibody-forming cells have been found in the bone marrow of immunized mice. In striking contrast to these results we found with the same assay that mouse bone marrow can contain large numbers of antibody-forming cells after intravenous (i.v.) immunization with the thymus-dependent sheep red blood cell (SRBC) antigens and the thymus-independent antigen Escherichia coli lipopolysaccharide (LPS).

In appendix publication I the primary and secondary antibody-forming cell (PFC) response of the mouse to i.v. injections of SRBC was studied.

During the primary response a great number of PFC appeared in the spleen while only a few PFC were found in the marrow. During the secondary response there was a clear PFC response in both the spleen and the bone marrow. The spleen contained the majority of PFC during the first phase of the response. The bone marrow PFC response was characterized by (1) a delayed appearance as compared with the spleen, and (2) an up to ten times as high PFC activity 
as in the spleen during the second phase of the response. IgM-PFC as well as IgG- and IgA-PFC could be demonstrated in the marrow. In the lymph nodes and Peyer's patches the number of PFC did not increase above the normal background level at any time after primary or secondary immunization.

In order to test whether the bone marrow PFC response was caused by migration of PFC from the spleen or by development in situ, mice were splenectomized shortly before the second injection of SRBC. It could be shown that splenectomy did not prevent the bone marrow PFC response. Because no PFC activity in the other lymphoid organs was observed the PFC activity of the marrow was concluded to be result from development of antibody-forming cells in situ.

The presence of a distinct anti-SRBC PFC response in mouse bone marrow during the secondary response might be related to the generation of memory cells after the first injection of the antigen. In appendix publication Il this possibility was investigated by means of cell transfer experiments.

$T$ cells, which are involved in an anti-SRBC PFC response, were shown to be very scarce in normal mouse bone marrow, which is considered to be the cause of the low PFC activity in the marrow during the primary response to SRBC.

In normal mouse bone marrow precursors of IgM-PFC but not of $\lg G$ - and $\operatorname{lgA}-P F C$ could be found. Priming with SRBC induced the appearance of IgM-, IgG-, IgA- and T-memory cells in the marrow. These B- and T-memory cells were shown to be specific for the antigen which induced their appearance. It was suggested in this paper that after a second injection of SRBC IgM-, IgG- and IgA-memory cells can differentiate with the help of T-memory cells within the bone marrow into $\lg M-, \lg G$ - and $\lg A-P F C$ respectively.

In appendix publication III the influence of the route of priming and dose of SRBC on the secondary bone ma rrow PFC activity was studied.

After intraperitoneal and subcutaneous priming the number of $\lg M_{-}, \lg G-$ and IgA-PFC in the bone marrow during the secondary response increased with the number of SRBC used for priming. After i.v. priming an optimal dose 
of SRBC was found for IgM-PFC as well as for IgG- and IgA-PFC to appear in mouse bone marrow during the secondary response. The peak secondary response in the bone marrow was found after priming with $10^{7}$ and with $10^{8}$ SRBC i.v.

The appearance of $\lg M-, \lg G$ - and IgA-memory cells in the bone marrow after i.v. immunization with $S R B C$ was shown to be dependent on the priming dose. The appearance of $\mathrm{lgG}$-memory cells required a higher dose of SRBC than the appearance of $\lg M$-memory cells, and the appearance of $\lg A$-memory cells required even more antigen.

The effect of the booster dose upon the PFC activity was studied in mice primed with $10^{7}$ SRBC i.v. and boosted with $10^{4}, 10^{6}$ or $10^{9}$ SRBC i.v. 2 months later. IgM-PFC as well as $\lg G$ and $\lg A-P F C$ were present in spleen and bone marrow at each booster dose tested. In each group of mice the PFC activity in the bone marrow rose to a level which surpassed the level in the other lymphoid organs between the 7 th and 10th day after the booster injection. Thus, independently of the booster dose, mouse bone marrow appeared to be the major source of PFC during the second phase of the secondary response to i.v. SRBC.

Appendix publication IV deals with the influence of splenectomy on the bone marrow PFC response to SRBC. Splenectomy before priming with an optimal dose of $10^{7}$ SRBC i.v. completely prevented bone marrow PFC activity during the secondary response. Cell transfer experiments revealed that splenectomy before priming with $10^{7}$ SRBC i.v. also prevented the appearance of B- and Tmemory cells in the bone marrow. The influence of splenectomy on both appearance of B- and T-memory cells and secondary bone marrow PFC activity could be partly overcome by priming with a higher antigen dose of $4 \times 10^{8}$ SRBC i.v. These results provided evidence that antibody formation in mouse bone marrow is dependent on the presence of memory cells.

In appendix publication $V$ the occurrence of PFC in mouse bone marrow was studied during the primary and secondary response to various doses of LPS. During the primary response i.v. doses of 1 and $10 \mu \mathrm{g}$ LPS were found to 
evoke a distinct IgM-PFC response in both spleen and bone marrow. The spleen contained the majority of PFC until about 5 days after immunization. In the course of the reaction the number of PFC in the bone marrow rose to a level which equalled or surpassed the level in the spleen. Doses of 0.001 , 0.01 and $0.1 \mu \mathrm{g}$ LPS i.v. only induced a IgM-PFC response in the spleen. Apparently there is a minimal threshold dose of LPS of about $1 \mu \mathrm{g}$ for anti-LPS PFC to appear in the bone marrow.

The secondary response was studied in mice primed with $1 \mu \mathrm{g}$ LPS i.v. and boosted with either $0.001,0.1$ or $10 \mu \mathrm{g}$ LPS i.v. three months later. After each dose tested the IgM-PFC activity in the spleen was several times higher than during the primary response. As was observed during the primary response i.v. doses of 0.001 and $0.1 \mu \mathrm{g}$ LPS did not evoke a PFC response in the bone marrow. A significant IgM-PFC response after boosting with $10 \mu \mathrm{g}$ LPS i.v. was found not only in spleen and bone marrow but also in thymus, lymph nodes, Peyer's patches and blood. From about 5 days after the booster injection the number of PFC in the bone marrow exceeded the total number found in all other lymphoid organs.

In conclusion during the primary response to SRBC PFC could be barely demonstrated in mouse bone marrow. However, a very distinct lgM-, lgG- and $\lg A-P F C$ activity was present in this organ during the secondary response to SRBC. LPS was found to be able to evoke an $\operatorname{lgM}$-PFC response in the bone marrow both during the primary and the secondary response. The anti-SRBC and anti-LPS PFC response in the bone marrow was characterized by (1) a delayed appearance of PFC as compared with the spleen, and (2) an up to ten times as high PFC activity as in all the other lymphoid organs together during the second phase of the response. In contrast to the secondary response to $S R B C$, the bone marrow required much more antigen than the spleen for anti-LPS PFC to appear.

Non-antibody-producing cells were found to be able to differentiate within the bone marrow into anti-SRBC PFC. The occurrence of these anti-SRBC PFC in the bone marrow probably requires specific memory cells. The results of 
splenectomy experiments suggest that secondary lymphoid organs are the site of origin of these memory cells. 


\section{SAMENVATTING}

Overeenkomstig hun bijdrage aan de antilichaamvorming worden lymfoïde organen in twee groepen ingedeeld: "primaire" en "secundaire" lymfö̈de organen. Bij zoogdieren worden beenmerg en thymus als primaire lymfoïde organen beschouwd, omdat deze organen betrokken zijn bij de vorming van lymfocyten: respectievelijk B-cellen en T-cellen. Deze lymfocyten kunnen de plaats waar ze gevormd worden verlaten en zorgen voor de vorming van antilichamen in secundaire lymfö̈de organen: milt, lymfklieren, plaques van Peyer en 'ander darmmgeassocieerd lymfoïd weefsel.

Bij konijn, cavia en westelijke blinde muis heeft men aangetoond, dat antilichaamvorming niet alleen kan plaatsvinden in secundaire lymfö̈de organen, maar ook in het beenmerg. De plaque-test, een direkte test om de aanwezigheid van antilichaamvormende cellen aan te tonen, is slechts zelden toegepast op het beenmerg. Voor zover deze test gebruikt is om antilichaamvormende cellen in het beenmerg aan te tonen, is deze vrijwel vitsluitend tot het beenmerg van muizen beperkt gebleven. Tot dusver heeft men met deze test slechts kleine aantallen antilichaamvormende cellen in het beenmerg van geïmmuniseerde muizen gevonden. Wii vonden echter met dezelfde test, dat het beenmerg van muizen grote aantallen antilichaamvormende cellen kan bevatten na intraveneuze (i.v.) immunisatie met schape-rode-bloedcellen (SRBC), een thymus-afhankelijk antigeen, en lipopolysaccharide (LPS) van Escherichia coli, een thymus-onafhankelijk antigeen.

In publikatie I van de appendix werden de primaire en secundaire humorale immunologische reaktie van de muis na i.v. injekties met SRBC bestudeerd.

Tijdens de primaire reaktie verscheen een groot aantal antilichaamvormende cellen (PFC) in de milt, en slechts een klein aantal in het beenmerg. Tijdens de secundaire reaktie was er een duidelijke PFC-reaktie, zowel in de milt als in het beenmerg. De milt bevatte het grootste aantal PFC tijdens de eerste 
fase van de reaktie. De PFC-reaktie in het beenmerg werd gekarakteriseerd door (1) een vertraagde verschijning vergeleken met de milt, en (2) een maximaal tien maal zo grote PFC-aktiviteit als in de milt tijdens de tweede fase van de reaktie. Zowel IgM-PFC als IgG- en IgA-PFC konden worden aangetoond in het beenmerg. Geen enkele maal na primaire of secundaire immunisatie steeg het aantal PFC in lymfklieren en plaques van Peyer vit boven het normale achtergrond-niveau.

Om te testen of de PFC-reaktie in het beenmerg veroorzaakt werd door migratie van PFC vanuit de milt of door ontstaan in situ, werden muizen kort voor de tweede injektie met SRBC gesplenectomeerd (d.w.z. hun milt werd operatief verwijderd). Er kon worden aangetoond, dat splenectomie de PFCreaktie in het beenmerg niet verhinderde. Omdat geen PFC-reaktie in de andere lymfoïde organen werd wargenomen, werd geconcludeerd dat de PFCreaktie in het beenmerg veroorzaakt wordt door het ontstaan van antilichaamvormende cellen in situ.

De anwezigheid van een duidelijke anti-SRBC PFC-reaktie in het beenmerg van de muis tijdens de secundaire reaktie zou verband kunnen houden met de vorming van memory-cellen na de eerste antigeen-injektie. In publikatie II van de appendix werd deze mogelijkheid onderzocht door middel van celtransfer-experimenten.

T-cellen, die betrokken zijn bij een anti-SRBC PFC-reaktie, bleken zeer schaars in het beenmerg van normale muizen. Dit wordt beschouwd als de oorzaak van de lage PFC-aktiviteit in het beenmerg tijdens de primaire reaktie tegen SRBC.

In het beenmerg van normale muizen konden wel IgM-B-cellen, maar geen $\lg G-$ en IgA-B-cellen voor SRBC worden aangetoond. Priming (d.w.z. de eerste immunisatie) met SRBC induceerde de verschijning van $\lg M-$, $\lg G-$, IgA- en T-memory-cellen in het beenmerg. Er werd aangetoond dat deze B- en T-memory-cellen specifiek waren voor het antigeen dat hun verschijning induceerde. In deze publikatie werd gesuggereerd dat na een tweede injektie met SRBC IgM-, IgG-en IgA-memory-cellen met behulp van T-memory-cellen 
in het beenmerg kunnen differentiëren tot respectievelijk IgM-, lgG- en $\operatorname{Ig} A-P F C$.

In publikatie III van de appendix werd de invloed van de wijze van priming en de dosis SRBC op de secundaire PFC-reaktie in het beenmerg bestudeerd.

$\mathrm{Na}$ intraperitoneale en subcutane priming nam het aantal $\lg M-$, lg $\mathrm{G}$ - en IgA-PFC in het beenmerg tijdens de secundaire reaktie toe met het aantal SRBC dat gebruikt was voor priming. Bij i.v. priming werd er een optimale dosis SRBC gevonden voor secundaire $\lg M-$, $\lg G$ - en $\lg A-P F C$-aktiviteit in het beenmerg. De sterkste secundaire reaktie in het beenmerg werd verkregen na i.v. priming met $10^{7}$ en met $10^{8}$ SRBC.

De verschijning van $\lg M-$, $\lg G$ - en $\lg A-m e m o r y-c e l l e n$ in het beenmerg na i.v. immunisatie met SRBC bleek afhankelijk van de gebruikte dosis. De verschijning van IgG-memory-cellen vereiste een hogere dosis SRBC dan de verschijning van IgM-memory-cellen, en voor de verschijning van lgA-memorycellen was nog meer antigeen nodig.

De invloed yan de dosis SRBC gebruikt voor tweede immunisatie werd bestudeerd in muizen die i.v. geprimed waren met $10^{7}$ SRBC en 2 maanden daarna i.v. geboosterd (d.w.z. voor de tweede maal geïmmuniseerd) waren met $10^{4}, 10^{6}$ of $10^{9}$ SRBC. Na elk van deze booster-doses waren er lgM-, lgGen $\lg A-P F C$ aanwezig in milt en beenmerg. In elke groep muizen steeg het aantal PFC in het beenmerg tussen de zevende en tiende dag na de tweede immunisatie vit boven het totale aantal in de andere lymfoïde organen samen. Blijkbaar is het beenmerg van de muis, onafhankelijk van de booster-dosis, de belangrijkste bron van PFC tijdens de tweede fase van de secundaire reaktie tegen $S R B C$ i.v.

Publikatie IV van de appendix handelt over de invloed van splenectomie op de PFC-reaktie tegen SRBC in het beenmerg. Splenectomie voor i.v. priming met een optimale dosis van $10^{7}$ SRBC verhinderde de verschijning van PFC in het beenmerg tijdens de secundaire reaktie. Celfransfer-experimenten toonden aan dat splenectomie voor i.v. priming met $10^{7}$ SRBC tevens de verschijning van B- en T-memory-cellen in het beenmerg voorkwàm. Deze invloed van splenec- 
tomie op de verschijning van B- en T-memory-cellen en secundaire PFCaktiviteit in het beenmerg kon gedeeltelijk teniet gedaan worden door i.v. te primen met een hogere antigeen-dosis, en wel met $4 \times 10^{8}$ SRBC. Deze resultaten gaven aanwijzingen, dat antilichaamvorming in het beenmerg van muizen afhankelijk is van de aanwezigheid van memory-cellen.

In publikatie $V$ van de appendix werd het vóórkomen van PFC in het beenmerg van muizen tijdens de primaire en secundaire reaktie op verschillende doses LPS bestudeerd.

Tijdens de primaire reaktie bleken i.v. doses van 1 en $10 \mu \mathrm{g}$ LPS een duidelijke IgM-PFC-reaktie in zowel milt als beenmerg op te wekken. De milt bevatte het grootste aantal PFC tot ongeveer 5 dagen na immunisatie. In de loop van de reaktie steeg het aantal PFC in het beenmerg tot een niveau dat het aantal in de milt evenaarde of overschreed. LPS-doses of 0,001, 0,01 en $0,1 \mu g$ i.v. induceerden alleen een IgM-PFC-reaktie in de milt. Blijkbaar is er een minimum-dosis LPS van ongeveer $1 \mu \mathrm{g}$ die bereikt moet worden voordat anti-LPS PFC in het beenmerg verschijnen.

De secundaire reaktie werd bestudeerd in muizen die i.v. geprimed waren met $1 \mu \mathrm{g}$ LPS en drie maanden later i.v. geboosterd waren met 0,001, 0, 1 of $10 \mu \mathrm{g}$ LPS. Na elke dosis die getest werd, was de $\lg M-P F C$-aktiviteit in de milt enige malen groter dan tijdens de primaire reaktie. Evenals tijdens de primaire reaktie waren doses van 0,001 en $0,1 \mu \mathrm{g}$ LPS i.v. niet in staat een PFC-reaktie in het beenmerg op te wekken. Na i.v. boosteren met $10 \mu \mathrm{g}$ LPS was er niet alleen in milt en beenmerg, maar ook in thymus, lymfklieren, plaques van Peyer en bloed een significante IgM-PFC-reaktie. Vanaf ongeveer 5 dagen na de booster-injektie was het aantal PFC in het beenmerg groter dan het totale aantal in alle andere lymfoïde organen samen.

Bovenstaande resultaten kunnen als volgt samengevat worden. Tijdens de primaire reaktie tegen SRBC konden PFC nauwelijks worden aangetoond in hef beenmerg van de muis. Er was echter een zeer duidelijke aktiviteit van IgM-, $\lg G-$ en IgA-PFC tijdens de secundaire reaktie tegen SRBC. LPS bleek zowel tijdens de primaire als tijdens de secundaire reaktie in staat een IgM-PFC-reak- 
tie in het beenmerg op te wekken. De anti-SRBC en anti-LPS PFC-reakties in het beenmerg werden gekenmerkt door (1) een vertraagde verschijning van PFC vergeleken met de milt, en (2) een maximaal tien maal zo grote PFC-aktiviteit als in alle andere lymfoïde organen samen tijdens de tweede fase van de reaktie. In tegenstelling tot de secundaire reaktie tegen SRBC was voor een anti-LPS PFC-reaktie in het beenmerg een hogere antigeen-dosis nodig dan voor een anti-LPS PFC-reaktie in de milt.

Er werden aanwijzingen verkregen, dat cellen die geen antilichamen produceren, in het beenmerg kunnen differentiëren tot anti-SRBC PFC. Waarschijnilik zijn voor een anti-SRBC PFC-reaktie in het beenmerg specifieke memory-cellen nodig. De resultaten van splenectomie-experimenten duiden erop, dat deze memory-cellen worden gevormd in secundaire lymfö̈de organen. 


\section{REFERENCES}

1. Pfeiffer, R. and Marx, 'Die Bildungsstätte der Choleraschutzstoffe.' Z. Hyg. u. Infektionskrakh., 27, 272-297, 1898.

2. Deutsch, L., 'Contribution à l'étude de l'origine des anticorps typhiques.' Ann. Inst. Past., 9, 689-727, 1899.

3. Romer, P., 'Experimentelle Untersuchungen uber Abrin-(Jequiritol)-Immunitut als Grundlagen einer rationellen Jequirity-Therapie.' Arch. f. Ophthalmol., 52, 72-142, 1901.

4. de Gara, P.F. and Angevine, D.M., 'Studies on the site of antibody formation in rabbits following intracutaneous injections of pneumococcus or of streptococcus vaccine.' J. exp. Med., 78, 27-39, 1943.

5. Oakley, C.L., Warrack, G.H. and Batty, I., 'Sites of antibody production.' J. Path. Bact., 6l, 179-194, 1949.

6. Thorbecke, G.J. and Keuning, F.J., 'Antibody formation in vitro by haemopoietic organs after subcutaneous and intravenous immunization.' J. Immunol., 70, 129-134, 1953.

7. Thorbecke, G.J., 'Over de vorming van antilichamen en gamma-globuline "in vitro" in bloedvormende organen.' Thesis, Groningen, The Netherlands, 1954.

8. Thorbecke, G.J. and Keuning, F.J., 'Antibody and gamma globul in formation in vitro in hemopoietic organs.' J. infect. Dis., 98, 157-171, 1956. 
9. Thorbecke, G.J., Asofsky, R.M., Hochwald, G.M. and Siskind, G.W., 'Gamma globulin and antibody formation in vitro. Ill. Induction of secondary response at different intervals after the primary; the role of secondary nodules in the preparation for the secondary response.' J. exp. Med., $116,295-310,1962$.

10. Langevoort, H.L., Asofsky, R.M., Jacobson, E.B., de Vries, T. and Thorbecke, G.J., 'Gamma globulin and antibody formation in vitro. 11. Parallel observations on histologic changes and on antibody formation in the white and red pulp of the rabbit spleen during the primary response, with special reference to the effect of endotoxin.' J. Immunol., 90, 60-71, 1963.

11. Carrel, A. and Ingebrigtsen, R., 'The production of antibodies by tissues living outside of the organism.' J. exp. Med., 15, 287-291, 1912.

12. Askonas, B.A., Humphrey, J.H. and Porter, R.R., 'On the origin of the multiple forms of rabbit $\gamma$-globulin.' Biochem. J., 63, 412-419, 1956.

13. Askonas, B.A. and White, R.G., 'Sites of antibody production in the guinea pig. The relation between in vitro synthesis of anti-ovalbumin and $\gamma$-globulin and distribution of antibody containing plasma cells.' Brit. J. exp. Path., 37, 61-74, 1956.

14. Askonas, B.A. and Humphrey, J.H., 'Formation of specific antibodies and $\gamma$-globulin in vitro. A study of the synthetic ability of various tissues from rabbits immunized by different methods.' Biochem. J., 68, 252-261, 1958.

15. Thorbecke, G.J., 'Gamma globulin and antibody formation in vitro. 1. Gamma globulin formation in tissues from immature and normal adult rabbits.' J. exp. Med., 112, 279-292, 1960. 
16. Asofsky, R. and Thorbecke, G.J., 'Sites of formation of immune globulins and of a component of $\mathrm{C}_{3}^{\prime}$. II. Production of immunoelectrophoretically identified serum proteins by human and monkey tissues in vitro.' J. exp. Med., 114, 471-483, 1961.

17. Thorbecke, G.J., Asofsky, R., Hochwald, G.M. and Siskind, G.W., 'Antibody production in vitro by spleen and bone marrow at various days after injection of antigen.' Fed. Proc., 20, 25, 1961.

18. van Buchem, F.L., 'Histologisch onderzoek van de plasmacellulaire reaktie en zijn plaats in de histophysiologie van de lymphklier.' Thesis, Groningen, The Netherlands, 1962.

19. Thorbecke, G.J., Asofsky, R., Hochwald, G.M. and Jacobson, E.B., 'Autoradiography of immunoelectrophoresis in the study of ${ }^{14} \mathrm{C}$-amino acid incorporation into serum proteins by tissues in vitro and in vivo.' In: Protides of the Biological Fluids (Ed. by H. Peeters), p. 125-127, Elsevier, Amsterdam, 1964.

20. Askonas, B.A., White, R.G. and Wilkinson, P.C., 'Production of $\gamma_{1}$ - and $\gamma_{2}$-antiovalbumin by various lymphoid tissues of the guinea pig.' Immunochemistry, $\underline{2}$, 329-336, 1965.

21. van Furth, R., Schuit, H.R.E. and Hijmans, W., 'The formation of immunoglobulins by human tissues in vitro. 111 . Spleen, lymph nodes, bone marrow and thymus.' Immunology, 11, 19-27, 1966.

22. Ludke, H., 'Ueber Antikörperbildung in Kulturen lebender Körperzellen.' Berl. klin. Wschr., 49, 1034-1035, 1912.

23. Reiter, H., 'Studien uber Antikörper: Bildung in vivo und in Gewebs- 
kulturen.' Z. Immun.-Forsch., 18, 5-61, 1913.

24. Fleming, W.A., Wilkinson, P.C. and White, R.G., 'Sites of biosynthesis of immunoglobulins in guinea pigs immunized with bacteriophage $\varnothing \times 174 . '$ Immunology, 13, 613-622, 1967.

25. McMillan, R., Longmire, R.L., Yelenosky, R., Lang, J.E., Heath, V. and Craddock, C.G., 'Immunoglobulin synthesis by human lymphoid tissues: normal bone marrow as a major site of $\mathrm{IgG}$ production.' J. Immunol., 109, 1386-1394, 1972.

26: Biprneboe, M. and Gormsen, H., 'Undersøgelser over Plasmacelleforekomsten ved experimentel Hyperglobulinaemie hos Kaniner.' Nord. Med., 9, 891-894, 1941.

27. Biprneboe, M. and Gormsen, H., 'Experimental studies on the role of plasma cells as antibody producers.' Acta Path. Microbiol. Scand., 20, 649-692, 1943.

28. Kolouch, F., Good, R.A. and Campbell, B., 'The reticulo-endothelial origin of the bone marrow plasma cells in hypersensitive states.' J. Lab. Clin. Med., 32, 749-755, 1947.

29. Fagreus, A., 'Antibody production in relation to the development of plasma cells. In vivo and in vitro experiments.' Acta med. Scand., suppl. 204, 3-122, 1948.

30. Good, R.A. and Campbell, B., 'Relationship of bone marrow plasmacytosis to the changes in serum gamma globulin in rheumatic fever.' Am. J. Med., 9, 330-342, 1950. 
31. Good, R.A., 'Studies on agammaglobulinemia. II. Failure of plasma cell formation in the bone marrow and lymph nodes of patients with agammaglobulinemia.' J. Lab. Clin. Med., 46, 167-181, 1955.

32. Landy, M., Sanderson, R.P. and Jackson, A.L., 'Humoral and cellular aspects of the immune response to the somatic antigen of Salmonella enteritidis.' J. exp. Med., 122, 483-504, 1965.

33. Janković, B.D. and Paunović, V.R., 'Immunological responses in the mole rat (Spalax leucodon).' Ann. Immunol. (Inst. Pasteur), 124C, 133-152, 1973.

34. Donnelly, N. and Sussdorf, D.H., 'Antigen-binding cells in central and peripheral lymphoid tissues of the rabbit.' Cell. Immunol., 15, 294-302, 1975.

35. Blịham, G.H., 'Histofysiologie van het helper $\mathrm{T}$ cellen systeem in het konijn.' Thesis, Groningen, The Netherlands, 1975, in press.

36. Hijmans, W., Schuit, H.R.E. and Hulsing-Hesselink, E., 'An immunofluorescence study on intracellular immunoglobulins in human bone marrow cells.' Ann. N.Y. Acad. Sci., 177, 290-305, 1971.

37. Silverman, A.Y., Yagi, Y., Pressman, D., Ellison, R.R. and Tormey, D.C., 'Monoclonal $\lg A$ and $\lg M$ in the serum of a single patient (SC). III. Immunofluorescent identification of cells producing $\lg A$ and $\operatorname{lgM} . '$ J. Immunol., 110, 350-353, 1973.

38. Knapp, W., Schuit, H.R.E., Bolhuis, R.L.H. and Hijmans, W., 'Surface immunoglobulins in chronic lymphatic leukaemia, macroglobulinaemia and myelomatosis.' Clin. exp. Immunol., 16, 541-552, 1974. 
39. Ràdl, J., Schuit, H.R.E., Mestecky, J. and Hijmans, W., 'The origin of monomeric and polymeric forms of $\lg A$ in man.' In: The immunoglobulin A System (Ed. by J. Mestecky and A.R. Lawton), p. 57-65, Plenum Press, New York, 1974.

40. Skvaril, F. and Morell, A., 'Distribution of $\lg A$ subclasses in sera and bone marrow plasma cells of 21 normal individuals.' In: The Immunoglobulin A System (Ed. by J. Mestecky and A.R. Lawton), p. 433-435, Plenum Press, New York, 1974.

41. Hijmans, W., 'The contribution of the bone marrow to the synthesis of immunoglobulins in man.' In: The Immunological Basis of Connective Tissue Disorders. (Ed. by L.G. Silvestri), p. 203-207, North-Holland Publishing Company, Amsterdam, 1975.

42. Vossen, J.M.J.J., 'The development of the B immune system in man.' Thesis, Leiden, The Netherlands, 1975.

43. Hijmans, W. and Schuit, H.R.E., 'Immunofluorescence studies on immunoglobulins in the lymphoid cells of human peripheral blood.' Clin. exp. Immunol., 11, 483-494, 1972.

44. Eidinger, D. and Pross, H.F., 'The immune response to sheep erythrocytes in the mouse. 1. A study of the immunological events utilizing the plaque technique.' J. exp. Med., 126, 15-33, 1967.

45. Chaperon, E.A., Selner, J.C. and Claman, H.N., 'Migration of antibodyforming cells and antigen-sensitive precursors between spleen, thymus and bone marrow.' Immunology, 14, 553-561, 1968.

46. Baker, P.J., Stashak, P.W., Amsbaugh, D.F. and Prescott, B., 
'Characterization of the antibody response to type III pneumococcal polysaccharide at the cellular level. 1. Dose-response studies and the effect of prior immunization on the magnitude of the antibody response.' Immunology, 20, 469-480, 1971.

47. Mellbye, O.J., 'Antibody-producing cells in bone marrow and other lymphoid tissues during the primary immune response in mice.' Int. Arch. Allergy, 40, 248-255, 1971.

48. Nedelkova, M. and Dobreva, A., 'Antikörper bildende Zellen im Knochenmark.' Folia Haematol., 95, 366-371, 1971.

49. Anderson, H.R. and Dresser, D.W., 'The long-term distribution of antibody-forming cells.' Eur. J. Immunol., 2, 410-413, 1972.

50. Cohen, J.J., 'Thymus-derived lymphocytes sequestered in the bone marrow of hydrocortison-treated mice.' J. Immunol., 108, 841-844, 1972.

51. Harding, B. and MacLennan, I.C.M., 'The distribution of antibody and antibody-producing cells after immunization with xenogeneic cells.' Immunology, 23, 35-43, 1972.

52. Cunningham, A.J., 'Antibody formation studied at the single cell level.' Progr. Allergy, 17, 5-50, 1973.

53. Cunningham, A.J., 'Large numbers of cells in normal mice produce antibody components of isologous erythrocytes.' Nature, 252, 749-751, 1974.

54. Lozzio, B.B. and Wargon, L.B., 'Immune competence of hereditarily asplenic mice.' Immunology, 27, 167-178, 1974. 
55. Chervenick, P.A., Boggs, D.R., Marsh, J.C., Cartwright, G.E. and Wintrobe, M.M., 'Quantitative studies of blood and bone marrow neutrophils in normal mice.' Am. J. Physiol., 215, 353-360, 1968.

56. Smith, L.H. and Clayton, M.L., 'Distribution of injected ${ }^{59} \mathrm{Fe}$ in mice.' Exp. Hemat., 20, 82-86, 1970.

57. Schofield, R. and Cole, L., 'An erythrocyte defect in splenectomized $X$-irradiated mice restored with spleen colony cells.' Brit. J. Haemat., $14,131-140,1968$.

58. Takahashi, T., Mond, J.J., Carswell, E.A. and Thorbecke, G.J., 'The importance of $\theta$ and $\mathrm{lg}$ bearing cells in the immune response to various antigens.' J. Immunol., 107, 1520-1526, 1971.

59. Kind, L.S. and Malloy, W.F., 'Development of reaginic antibody-forming cells in the spleen and bone marrow of immunized mice.' J. Immunol., 112, 1609-1612, 1974.

60. Petrov, R.V., Mikhajlova, A.A., Stepanenko, R.N. and Zakharova, L.A., 'Cell interactions in the immune response: effect of humoral factor released from bone marrow cells on the quantity of mature antibody producers in culture of immune lymph node cells.' Cell. Immunol., 17, 342-350, 1975.

61. Zaalberg, O.B., personal communication.

62. Gisler, R.H. and Fridman, W.H., 'Suppression of in vitro antibody synthesis by immunoglobulin-binding factor.' J. exp. Med., 142, 507-511, 1975.

63. Shands, J.W., 'The physical structure of bacterial lipopolysaccharides' In: Microbial Toxins (Ed. by G. Weinbaum, S. Kadis and S.J. Ajl), 
4, p. 127-144, Academic Press, New York, 1971.

64. van Furth, R., Schuit, H.R.E. and Hijmans, W., 'The formation of immunoglobulins by human tissues in vitro. IV. Circulating lymphocytes in normal and pathological conditions' Immunology, 11, 29-40, 1966.

65. Ràdl, J., Dooren, L.J., Eijsvoogel, V.P., van Went, J.J. and Hijmans, W. 'An immunological study during post-transplantation follow-up of a case of severe combined immunodeficiency.' Clin. exp. Immunol., 10, 367-382, 1972.

66. Haskill, J.S., Legge, D.G. and Shortman, K., 'Density distribution analysis of cells forming 195 hemolytic antibody in the rat.' J. Immunol., 102, 703-712, 1969.

67. Haaijman, J.J., personal communication.

68. Katz, D.H. and Benacerraf, B., 'The regulatory influence of activated $T$ cells on $B$ cell responses to antigen.' In: Advances in Immunology (Ed. F.J. Dixon and H.G. Kunkel), 15, 1-94, Academic Press, New York, 1972.

69. Raff, M.C., 'Surface antigenic markers for distinguishing $T$ and $B$ lymphocytes in mice.' Transpl. Rev., 6, 52-80, 1971.

70. Hobson, D., Porter, K.A. and Whitby, J.L., 'The immunological response of marrow treated $X$-irradiated rabbits to bovine gamma-globulin.' Brit. J. exp. Path., 40, 15-24, 1959.

71. Stoloff, I.L., 'The production of antibody by transferred bone marrow.' J. Immunol. 85, 304-308, 1960. 
72. Gengozian, N., Makinodan, T. and Shekarchi, I.C., 'Transplantation of antibody-forming cells in lethally irradiated mice.' J. Immunol., $\underline{6}$ 113-122, 1961.

73. Stoner, R.D. and Bond, V.P., 'Antibody formation by transplanted bone marrow, spleen, lymph nodes and thymus cells in irradiated recipients.' J. Immunol., 91, 185-196, 1963.

74. Claman, H.N., Chaperon, E.A. and Triplett, R.F., 'Immunocompetence of transferred thymus-marrow cell combinations.' J. Immunol., 97, 828-832, 1966.

75. Mitchell, G.F. and Miller, J.F.A.P., 'Cell to cell interaction in the immune response. II. The source of hemolysin-forming cells in irradiated mice given bone marrow and thymus or thoracic duct lymphocytes.' J. exp. Med., 128, 821-837, 1968.

76. Taylor, R.B., 'Cellular cooperation in the antibody response of mice to two serum albumins: specific function of thymus cells.' Transpl. Rev., 1, 114-149, 1969.

77. Chiller, J.M., Habicht, G.S. and Weigle, W.O., 'Cellular sites of immunologic unresponsiveness.' Proc. Nat. Acad. Sci., 65, 551-556, 1970.

78. Jehn, U.W. and Karlin, L., 'Independent action of thymus and bone marrow cells during the secondary response of direct plaque-forming cells.' J. Immunol., 106, 946-950, 1971.

79. Kateley, J.R. and Friedman, H., 'Modulation of antibody synthesis by cholera exotoxin: influence on helper thymocytes.' Cell. Immunol., 18 , 239-245, 1975. 
80. Miller, H.C. and Cudkowicz, G., 'Antigen-specific cells in mouse bone marrow. II. Fluctuation of the number and potential of immunocyte precursors after immunization.' J. exp. Med., 133, 973-986, 1971.

81. Röpke, C. and Everett, N.B., 'Migration of small lymphocytes in adult mice demonstrated by parabiosis.' Cell Tissue Kinet., Z, 137-150, 1974.

82. Osmond, D.G. and Nossal, G.J.V., 'Differentiation of lymphocytes in mouse bone marrow. Il. Kinetics of maturation and renewal of antiglobulin-binding cells studied by double labeling.' Cell. Immunol., 13, 132-145, 1974.

83. Basten, A., Miller, J.F.A.P., Warner, N.L. and Pye, J., 'Specific inactivation of thymus-derived $(T)$ and non-thymus-derived (B) lymphocytes by 125 I-labelled antigen.' Nature New Biol., 231, 104-106, 1971.

84. Everett, N.B. and Caffrey, R.W., 'Radioautographic studies of bone marrow small lymphocytes.' In: The Lymphocyte in Immunology and Haemopoiesis (Ed. by J.M. Yoffey), p. 108-119, Edward Arnold, London, 1967.

85. Joel, D.D., Hess, M.W. and Cottier, H., 'Magnitude and pattern of thymic lymphocyte migration in neonatal mice.' J. exp. Med., 135, 907-923, 1972.

86. Ropke, C., Hougen, H.P. and Everett, N.B., 'Long-lived T and B lymphocytes in the bone marrow and thoracic duct lymph of the mouse.' Cell. Immunol., 15, 82-93, 1975. 


\section{DANKWOORD}

Graag wil ik mijn dank betuigen aan allen die hebben bijgedragen aan het tot stand komen van dit proefschrift. In het bijzonder dank ik mijn promotor Prof. dr. O. Vos voor de mogelijkheden die hij mij heeft geboden en voor de stimulerende wijze waarop hij dit onderzoek heeft begeleid. Zijn voortdurende betrokkenheid bij het onderzoek van de afdeling, ondanks de zware belasting die het decanaat van onze Faculteit met zich meebrengt, heb ik zeer gewaardeerd.

Dr. W. Hijmans en Dr. O.B. Zaalberg ben ik zeer erkentelijk voor hun grote belangstelling voor de voortgang van het onderzoek. De bijdrage die zij en hun medewerkers leverden tijdens de wekelijkse werkbespreking en daarbuiten, is van grote warde geweest. Voorts dank ik hen en Prof. dr. D.W. van Bekkum voor het kritisch doornemen van de inleidende hoofdstukken van dit proefschrift.

Dr. J.M.N. Willers en Drs. G.H. Blijham dank ik hartelijk voor enkele stimulerende gesprekken en waardevolle suggesties.

Drs. F. Meima, die als keuzepraktikant en student-assistent aan dit onderzoek deelnam, ben ik zeer veel dank verschuldigd voor zijn bijdrage in de beginfase van dit onderzoek. Mede dankzii zijn enorme inzet, meestal tot laat op de avond, kon binnen enkele maanden de basis voor dit proefschrift worden gelegd. Mevr. G.M. van Pelt-van der Meulen en de heer A. van Oudenaren dank ik zeer hartelijk voor hun geweldige hulp. Alleen dankzij hen konden de (vaak te) omvangrijke experimenten uitgevoerd worden.

Vele medewerkers van de afdeling Celbiologie en Genetica verleenden belangrijke steun aan dit onderzoek. Met name dank ik Drs. W.B. van Muiswinkel, Drs. W. van Ewijk en Drs. J. Rozing voor de prettige samenwerking bij enkele experimenten en Mevr. M.J. Heukels-Dully, M.S. voor het kritisch doornemen van de Engelse tekst van manuscripten. Voorts ben ik dank verschuldigd aan 
de heer J. Bos voor de verzorging van de proefdieren; aan Mevr. A.M. Godijn en Mej. J.A. Bolman voor het schoonmaken en steriliseren van het glaswerk; aan Mej. M. van Duuren en de heer P. Hartwijk voor het tekenen van de grafieken; aan de heren J.G.H. Fengler en T.M. van Os voor het fotografische werk en aan Mevr. G.M. van Pelt-van der Meulen en Mevr. I. van Horssenvan der Kaai voor het verrichte typewerk.

Tenslotte dank ik mijn vrouw. Van allen hier genoemd leverde zij de minst direkte èn de belangrijkste bijdrage aan het tot stand komen van dit proefschrift. Ik ben haar het meest dankbaar. 


\section{CURRICULUM VITAE}

In 1966 diploma HBS-B aan de Christelijke Scholengemeenschap "Groen van Prinsterer" te Vlaardingen. Van 1966 tot februari 1972 studie biologie aan de Rijksuniversiteit te Utrecht. Doctoraalexamen mer hoofdvak Microbiologie bij Dr. J.M.N. Willers (onderzcek naar de chemische struktuur van de antigene determinant van het Type IV-antigeen bij streptococcen) en Dr. J.A.M. Kerckhaert (onderzoek naar de celtypen welke betrokken zijn bij de graft-versushost reaktie in vitro). Bijvakken: Pedagogiek en Didaktiek bij Drs. F. Keuchenivis en Drs. H.J. Saaltink en Scheikunde met Onderwijsbevoegdheid. Van 1967 tot 1973 part-time leraar biologie en scheikunde aan de Christelijke Scholengemeenschap "Johannes Calvijn" te Rotterdam. In 1970 en 1971 student-assistent op het Laboratorium voor Microbiologie te Utrecht. Sedert februari 1972 werkzaam binnen de vakgroep Celbiologie en Genetica van de Erasmus Universiteit te Rotterdam. Binnen deze vakgroep werd het onderzoek verricht dat in dit proefschrift wordt beschreven. 
APPENDIX PUBLICATION I 


\title{
Antibody Formation in Mouse Bone Marrow
}

\author{
I. EVIDENCE FOR THE DEVELOPMENT OF PLAQUE-FORMING CELLS \\ $I \mathcal{N} S I T U$
}

\begin{abstract}
R. Benner, F. Meima, Gerda M. van der Meulen and W. B. van Muiswinkel Department of Cell Biology and Genetics, Erasmus University, P.O. Box 1738 Rotterdam, The Netherlands
\end{abstract}

(Received 4th Fune 1973; accepted for publication 20th fuly 1973)

\begin{abstract}
Summary. Mouse bone marrow as a source of plaque-forming cells ( $\mathrm{PFC}$ ) was studied by single and multiple intravenous injections of sheep erythrocytes (SRBC). In the primary response a great number of $\mathrm{PFC}$ appeared in the spleen while only a few showed up in the marrow. In the secondary response there is a clear PFCresponse in both the spleen and the bone marrow. The spleen contains the majority of PFG until about 9 days after the second injection. In the course of the reaction, however, the number of PFC in the bone marrow rises to a level which surpasses the level in the spleen. IgM-PFG as well as IgG-PFG and IgA-PFC could be demonstrated in the marrow. In the lymph nodes and Peyer's patches the number of PFC did not increase above the normal background level at any time after the primary or secondary immunization. In order to test whether the bone marrow PFC-response is caused by a migration of PFC from the spleen or by development in situ, mice were splenectomized shortly before the second injection of SRBC. It could be shown that splenectomy does not prevent the bone marrow PFCresponse. Because no activity in the other lymphoid organs was observed, it is concluded that the PFC activity of the marrow is caused by development in situ.
\end{abstract}

\section{INTRODUCTION}

Antibody- and $\gamma$-globulin synthesis can take place in bone marrow. In the early part of the century it was stated that the bone marrow of immunized guinea-pigs (Lüdke, 1912) and rabbits (Lüdke, 1912; Reiter, 1913) is capable of antibody-production in vitro. In recent years antibody- and $\gamma$-globulin synthesis in the bone marrow were reported for guinea-pig (Askonas and White, 1956; Askonas, White and Wilkinson, 1965; Fleming, Wilkinson and White, 1967), rabbit (Thorbecke and Keuning, 1953, 1956; Askonas and Humphrey, 1958; Thorbecke, 1960; Thorbecke, Asofsky, Hochwald and Siskind, 1962), human (Asofsky and Thorbecke, 1961; van Furth, 1966; McMillan, Longmire, Yelenosky, Lang, Heath and Craddock, 1972) and monkey (Asofsky and Thorbecke, 1961) bone marrow in vitro.

Studies in rabbits (Kolouch, Good and Campbell, 1947) and in man (Good, 1955) provided evidence for a positive correlation between the plasma cell content of the bone marrow and the serum titre after intensive antigenic stimulation. Recently Hijmans, Schuit and Hulsing-Hesselink (1971) and Silverman, Yagi, Pressman, Ellison and 
Tormey (1973) reported studies of human bone marrow cells analysed for the presence of immunoglobulins with the fluorescent antibody technique. The $\kappa / \lambda$ ratio and the percentage distribution of cells of the lymphoid series which were positive for the heavy chains of the major classes $(\alpha, \mu$ and $\gamma)$ showed a striking similarity with the $\kappa / \lambda$ ratio in the serum and with the percentage distribution of the serum immunoglobulins, if corrected for pool size and metabolic rate. Hijmans and Schuit (1972) concluded that in humans bone marrow is a major source of immunoglobulins.

So far mouse bone marrow has not been demonstrated to contain a substantial number of plaque-forming cells (PFC) after immunization (Friedman, 1964; Eidinger and Pross, 1967; Chaperon, Selner and Claman, 1968; Mellbye, 1971; Cohen, 1972; Anderson and Dresser, 1972). However, some activity in the bone marrow was found with an increasing interval after immunization with sheep red cells (SRBC) (Eidinger and Pross, 1967; Chaperon et al., 1968; Mellbye, 1971; Anderson and Dresser, 1972).

We have studied the primary and secondary response against SRBC by the haemolytic plaque assay in mouse bone marrow. The activity of the marrow was compared with the activity of the other lymphoid organs. We have shown that after two intravenous injections with SRBC, mouse bone marrow contains a considerable part of the total number of PFG. The presence of these large numbers of PFC in bone marrow may be due to a migration of PFC from the spleen. Such transport is suggested in the literature (Langevoort, Asofsky, Jacobsen, de Vries and Thorbecke, 1963, van Furth et al., 1966; Chaperon et al., 1968; Hijmans and Schuit, 1972). We tested this possibility by studying the secondary response of bone marrow in mice, splenectomized shortly before their second injection of SRBC.

\section{MATERIALS AND METHODS}

Mice

(C57Bl/Rij $\times$ CBA/Rij) $F_{1}$ female mice, 20 weeks old were used. They were purchased from the Medical Biological Laboratory (Rijswijk, The Netherlands).

\section{Immunization}

For primary immunization, the mice received an intravenous injection of $4 \times 10^{8}$ $\mathrm{SRBC}$. This injection was repeated in 5 weeks for the secondary immunization.

\section{Splenectomy}

Spenectomy and sham-splenectomy were performed 1 day before the second injection of SRBC. The mice were anaesthetized with an intraperitoneal injection of $70 \mathrm{mg} / \mathrm{kg}$ body weight Nembutal (Abbott S. A., Saint-Rémy-sur-Avre, France). There was no post-operative mortality.

\section{Preparation of cell suspensions}

At various times following immunization four or five animals were killed. Immediately after killing the mice with ether, the spleens, femurs, peripheral lymph nodes (inguinal, brachial and axillary), mesenteric lymph nodes and Peyer's patches were removed and brought into a balanced salt solution (BSS). This solution was prepared according to Mishell and Dutton (1967) and was always supplemented with 5 per cent newborn calf serum.

Bone marrow was obtained by flushing the femurs with BSS. Spleens, lymph nodes, 
Peyer's patches and bone marrow were minced with scissors and squeezed through a nylon-gauze filter to give a single cell suspension.

\section{Assay for $P F C$}

The method for detection of PFC developed by Cunningham and Szenberg (1968) was adopted with some modifications as described by Zaalberg, van der Meul and Twisk (1968). One coverslip of $60 \times 24 \mathrm{~mm}$ was used per microscope slide. The maximum concentration of cell suspension was $2 \times 10^{7}$ cells $/ \mathrm{ml}$ and a volume of $0.4 \mathrm{ml}$ was used for each test. The chambers were incubated at $37^{\circ}$ for 2 hours. The number of IgM-PFC was calculated from a direct assay in which the slides were developed with guinea-pig complement (Flow Laboratories, Rockville, U.S.A.) only. The number of IgM-PFC+ IgG-PFG was calculated from an indirect assay in which the slides were developed with guinea-pig complement and rabbit-anti-mouse-IgG. The number of IgG-PFC was obtained by subtracting the number of PFC obtained in the direct assay from those obtained in the indirect assay. The number of IgA-PFG was calculated in a similar way employing rabbit-anti-mouse-IgA. From the results of the femoral bone marrow the number of PFC present in the marrow of the whole animal was estimated, using the data of Chervenick, Boggs, March, Cartwright and Wintrobe (1968), who showed that in mice one femur contains 5.9 per cent of the marrow.

\section{Hyperimmune serum}

For hyperimmune-anti-SRBG serum $(\mathrm{C} 57 \mathrm{Bl} / \mathrm{Rij} \times \mathrm{CBA} / \mathrm{Rij}) \mathrm{F}_{1}$ female mice received four injections of $4 \times 10^{8} \mathrm{SRBC}$. The first injection was given intravenously, and subsequent ones were administered every other week intraperitoneally. The agglutination titre of the serum used was $1: 2^{16}$.

\section{Statistics}

The standard deviation (S.D.) associated with $p$ plaques counted was calculated as the square root of $p+0.004 \times p^{2}$. This formula was drawn up by Jerne for the agar plaque assay. For calculation of the 95 per cent confidence limits the formula $p+$ two S.D. was used. The presence of IgG and IgA was accepted as significant when there was no overlap between the upper limit in the direct assay and the lower limit in the indirect assay.

\section{RESULTS}

\section{PRIMARY RESPONSE}

After a single i.v. injection of $4 \times 10^{8} \mathrm{SRBC}$ the main PFC-activity could be observed in the spleen (Fig. 1). Only slight activity was detected in the bone marrow; during the early response some IgM-PFC appeared, but were not detected in significant quantities. However, after 27 days small numbers of IgM-, IgG- and IgA-PFC could be found in the marrow. In the peripheral lymph nodes, the mesenteric lymph node, and Peyer's patches the presence of PFG above the normal background level could not be demonstrated.

A second i.v. injection of $4 \times 10^{8} \mathrm{SRBC}$, given 5 weeks after the first one, resulted in 


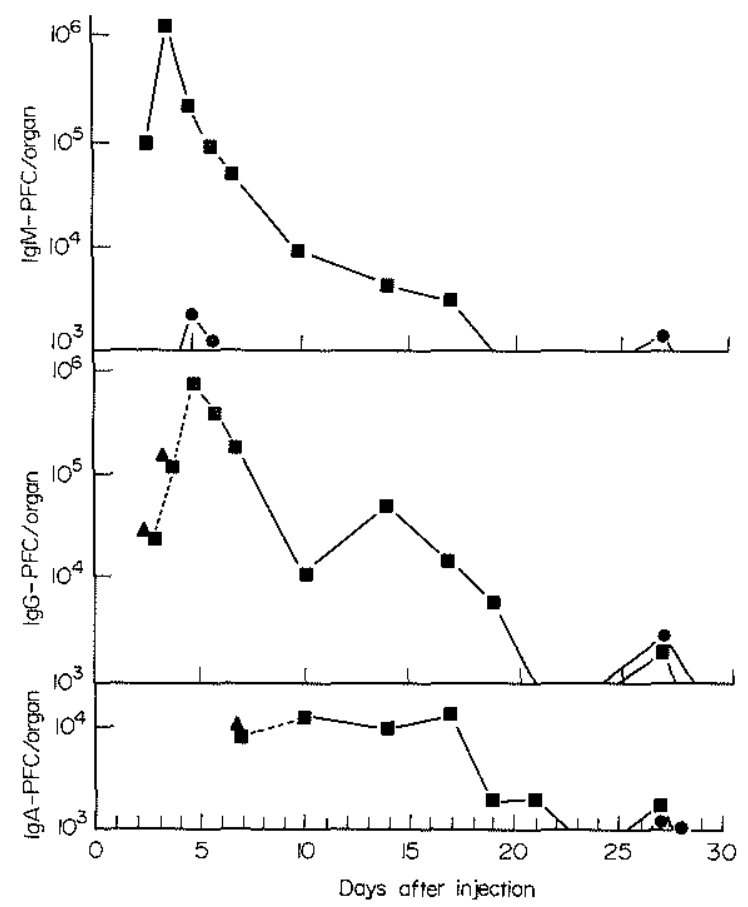

Frg. 1. Number of PFC in mouse spleen and bone marrow after an i.v. injection of $4 \times 10^{8} \mathrm{SRBC}$. ( $\mathbf{m})$ Spleen and ( $)$ bone marrow. Where ( $\boldsymbol{\Lambda}$ ) is added to an experimental point it means that the number of IgG-PFC or IgA-PFC above the level of IgM-PFC was not significant.

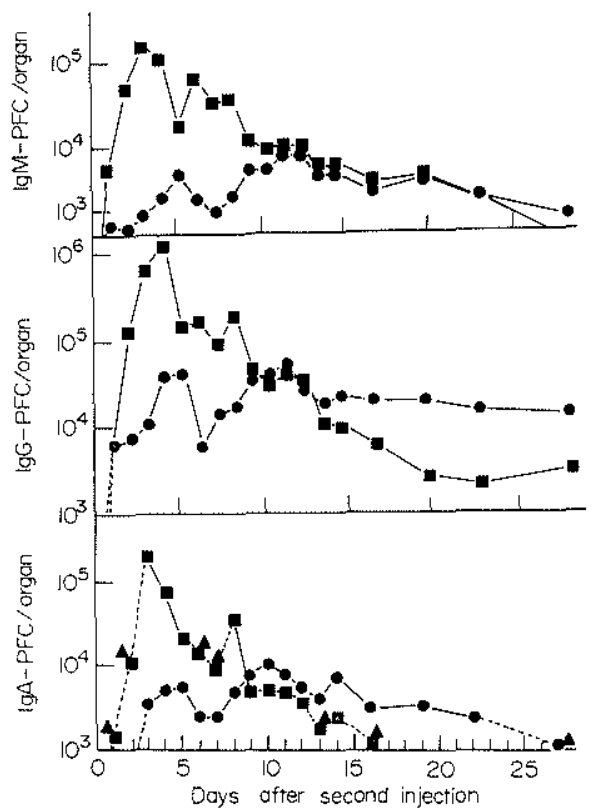

FIG. 2. Number of PFC in mouse spleen and bone marrow after two i.v. injections of $4 \times 10^{8} \mathrm{SRBC}$. The second injection was given 5 weeks after the first. ( $\boldsymbol{\omega})$ Spleen and ( $)$ bone marrow. Where ( $\boldsymbol{\Delta}$ ) is added to an experimental point it means that the number of IgG-PFC or IgA-PFC above the level of IgM-PFC was not significant. 
the rapid appearance of IgM-, IgG- and IgA-PFC in the spleen as well as in the bone marrow (Fig. 2). During the first 9-10 days the spleen contained the majority of the PFC; however, in the course of the reaction the bone marrow became more important as a source of PFC. After the 9th day the bone marrow contained as many IgM-, IgG- and $\mathrm{IgA-PFG}$ as the spleen. After the 13th day IgG-PFG in the bone marrow were even more numerous. The number of $\mathrm{PFG}$ in peripheral lymph nodes, mesenteric lymph node and Peyer's patches remained at the normal background level.

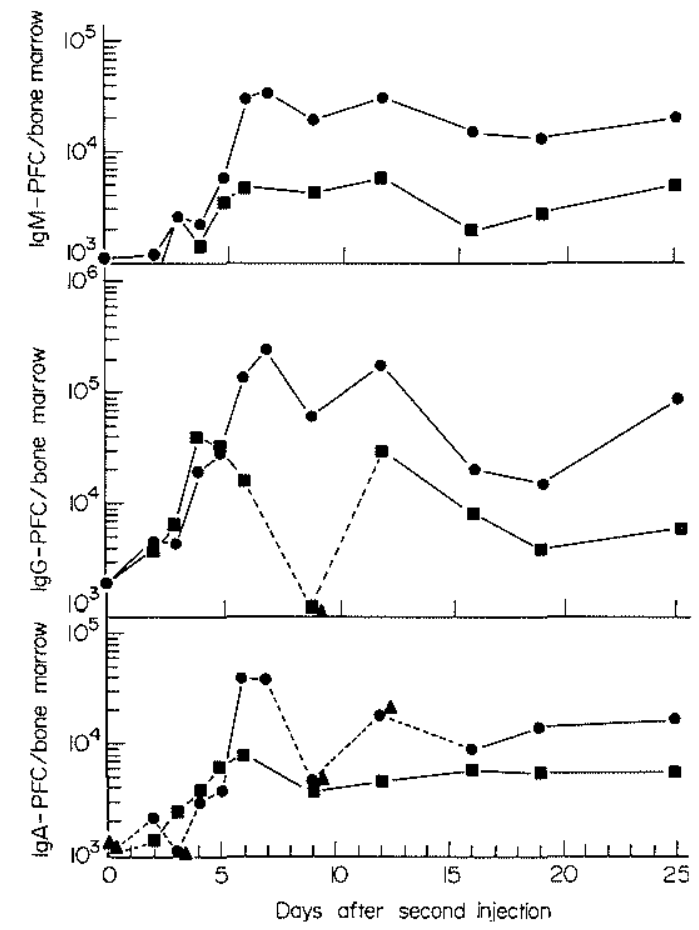

FIG. 3. Number of PFG in mouse bone marrow after two i.v. injections of $4 \times 10^{8} \mathrm{SRBC}$. The second injection was given 5 weeks after the first. ( $\mathbf{E})$ Sham-splenectomy and (•) splenectomy. Shamsplenectomy and splenectomy were performed I day before the second injection of SRBC. Where (A) is added to an experimental point it means that the number of IgG-PFC or IgA-PFG above the level of IgM-PFG was not significant.

\section{SECONDARY RESPONSE OF BONE MARROW AFTER SPLENEGTOMY}

In the literature it has been suggested that PFG can migrate from spleen to bone marrow (Langevoort et al., 1963; van Furth et al., 1966; Chaperon, et al., 1968; Hijmans and Schuit, 1972). To find out whether or not this migration causes the activity of the bone marrow during secondary response in our system, an experiment was performed in which mice were splenectomized 1 day before the second intravenous injection of SRBC.

Fig. 3 shows that splenectomy is not able to prevent the activity of the bone marrow in the secondary response. Once again, peripheral lymph nodes, mesenteric lymph node and Peyer's patches did not show an increase of the number of PFC. Therefore the PFC activity in bone marrow appears to be caused by a development of PFC in situ.

It is noteworthy that the bone marrow of the splenectomized animals as compared with the sham-splenectomized ones demonstrates an even higher PFC activity. Two ex- 


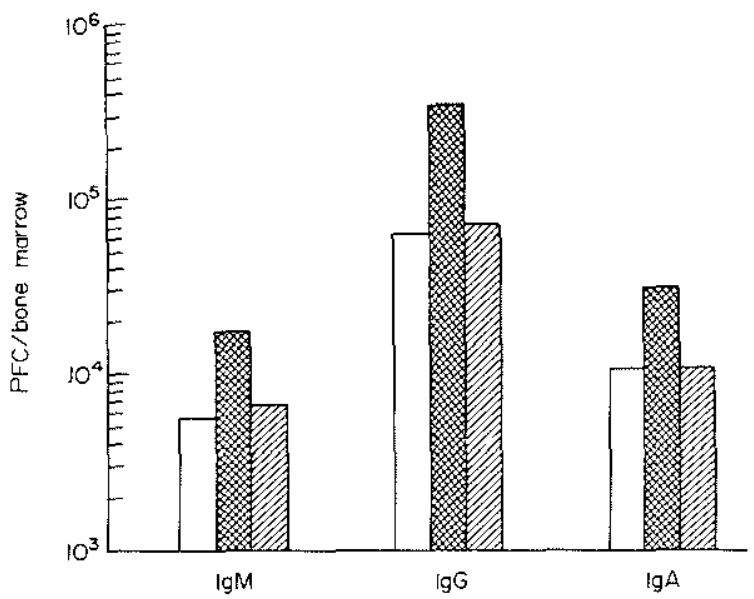

FIG. 4. Number of PFC in mouse bone marrow 6 days after the last of two i.v. injections of $4 \times 10^{8}$ SRBC. The second injection was given 5 weeks after the first. Open columns, sham-splenectomy; cross-hatched columns, splenectomy; hatched columns, splenectomy plus an i.v. injection of $0.5 \mathrm{ml}$ hyperimmune anti-SRBC-serum. Operations were performed 1 day before the second injection of SRBC. The serum was administered 2 days after the second antigen injection.

planations for this phenomenon can be postulated. One explanation includes the absence of suppressing antibodies from the spleen. A regulatory effect of antibodies on the PFC response has been described (Uhr and Möller, 1968). This possibility was tested by giving

splenectomized mice an intravenous injection of $0.5 \mathrm{ml}$ hyperimmune anti-SRBCserum on the second day after the second antigen administration. The titre observed in normal mice injected with this amount of anti-SRBC-serum was $2^{14}$. Fig. 4 shows that the administration of hyperimmune anti-SRBC-serum suppressed the bone marrow PFC response. Another explanation could be that in the absence of the spleen more antigen is taken up by the bone marrow. The influence of the antigen supply on the bone marrow PFG activity was studied by challenging two groups of intact mice with doses of $4 \times 10^{8}$ and $10^{9} \mathrm{SRBC}$ respectively. As shown in Fig. 5 an increased amount of SRBC

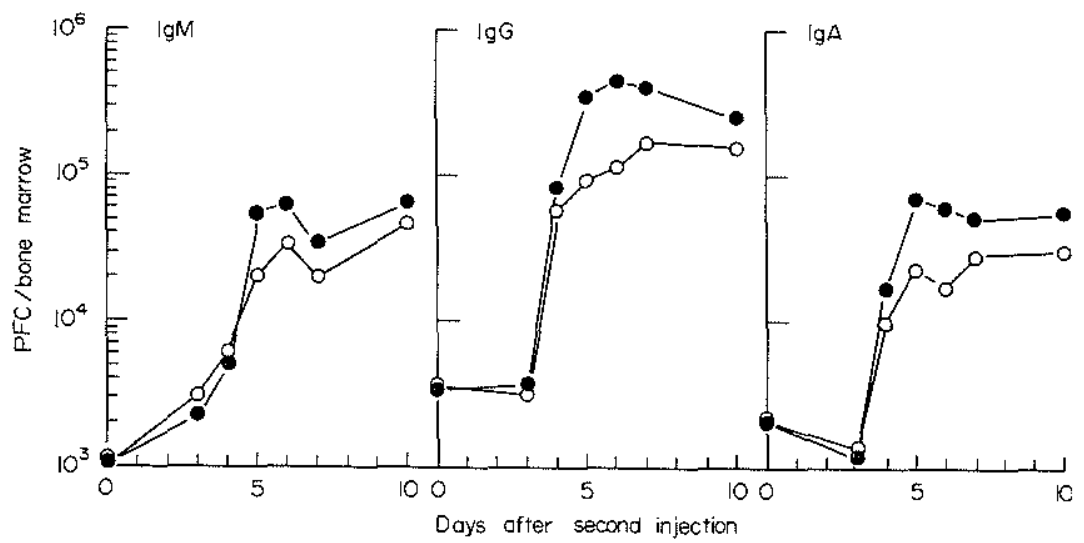

Frg. 5. Number of PFG in mouse bone marrow after two i.v. injections of SRBC. Both groups received a first injection of $4 \times 10^{8}$ SRBC. One group $(\bullet)$ received a second injection of $10^{9}$ SRBC; the other group (O) was inoculated with $4 \times 10^{8} \mathrm{SRBC}$. 
stimulated the bone marrow to a somewhat greater activity. It is questionable whether this greater activity of the bone marrow is a direct consequence of this increased antigen supply. It is possible that the larger amount of SRBC reduces the concentration of free circulating anti-SRBC-antibodies from the primary response, thereby diminishing the negative feed back of these antibodies upon the secondary response of the marrow.

\section{DISCUSSION}

The bone marrow is generally considered to be a primary lymphoid organ, since among its progeny are lymphocytes which are of major importance for the immunological capacity of other lymphoid organs (Miller, 1968). In vitro experiments (Thorbecke and Keuning, 1953, 1956; Askonas and Humphrey, 1958; Askonas and White, 1956; Langevoort et al., 1963; Askonas et al., 1965; Fleming et al., 1967) demonstrate that bone marrow itself is capable of antibody synthesis. In these experiments the authors used bone marrow of primed organisms. Bone marrow of unprimed organisms is unable to respond to antigenic stimulation in vitro (Thorbecke and Keuning, 1956; Langevoort et al., 1963; McMillan et al., 1972).

Calculations of the contribution of the bone marrow to the overall production of immunoglobulins suggest that the marrow may be a major source of immunoglobulins (Askonas and White, 1956; Hijmans and Schuit, 1972; McMillan et al., 1972).

Experiments in which the activity of the bone marrow was tested with the haemolytic plaque assay have been reported, with mice used as experimental animals (Friedman, 1964; Eidinger and Pross, 1967; Chaperon et al., 1968; Mellbye, 1971; Cohen, 1972; Anderson and Dresser, 1972). Calculation of the total amount of PFC in mouse bone marrow requires an estimation of the number of bone marrow cells in the entire animal. For our calculations we made use of the results of Chervenick et al. (1968). These authors demonstrated with ${ }^{59} \mathrm{Fe}$-labelling that one femur of a mouse contains 5.9 per cent of its bone marrow. Although the distribution of ${ }^{59} \mathrm{Fe}$ is not necessarily representative for the distribution of lymphocytes, it gives a clue for the total amount of bone marrow. Using this estimation we found a small number of PFC in the bone marrow during the late phase of the primary response after intravenous immunization (Fig. 1). This observation is consistent with the results of others (Eidinger and Pross, 1967; Chaperon et al., 1968; Mellbye, 1971; Anderson and Dresser, 1972) using other routes of immunization. However, during the secondary response the bone marrow is particularly active, even in the early phase (Fig. 2). In a comparable experimental approach Eidinger and Pross (1967) found a small number of IgG-PFC in the bone marrow during the early response after a second intradermal immunization.

It is worth noting that the bone marrow needs a longer period of induction than the spleen. It was also demonstrated in rabbits that non-splenic sites have a longer lag time than the spleen after intravenous injections of SRBC (Taliaferro and Taliaferro, 1952). The spleen appears to synthesize antibody more rapidly after intravenous injections of SRBC than the bone marrow.

From the 9 th to the 13 th day the bone marrow contains approximately as many IgM-, IgGand IgA-PFC as the spleen. From the 13th day on the major part of the total number of IgG$\mathrm{PFC}$ is found in the bone marrow. This strong IgG-PFC activity corresponds well with the other results published (van Furth et al., 1966; McMillan, 1972). It has been suggested in the literature (Langevoort et al., 1963; van Furth et al., 1966; Chaperon et al., 1968; 
Hijmans and Schuit, 1972) that antibody-forming cells from the peripheral lymphoid organs home to the bone marrow. Because only spleen and bone marrow showed a PFC activity during the secondary response in our experiments we could test this suggestion by splenectomy before the second injection of SRBG.

It was demonstrated that splenectomy does not prevent the secondary response of the bone marrow. Probably the bone marrow PFC originate in situ, because after splenectomy the mesenteric lymph node, the peripheral lymph nodes and Peyer's patches did not show a PFG-response.

The question then arises as to why the bone marrow is barely capable of antibody synthesis in the primary response, whereas a $\mathrm{PFC}$ activity in the secondary response can be clearly demonstrated. The most plausible explanation is that memory cells appear in the bone marrow after antigenic stimulation, so that a subsequent dose of the antigen triggers the development of B memory-cells into PFG. Experiments confirming this explanation will be described in a following paper. Finally it is interesting that the bone marrow compensates for the loss of the spleen by a greater number of PFC in comparison with the sham-splenectomized animals. The absence of regulating antibodies from the spleen (Fig. 4) is probably the cause of this greater activity of the bone marrow.

\section{AGKNOWLEDGMENTS}

We are very indebted to Professor Dr O. Vos, Dr W. Hijmans (Institute for Experimental Gerontology, Rijswijk, The Netherlands), and Dr O. B. Zaalberg (The Medical Biological Laboratory, Rijswijk, The Netherlands) for helpful suggestions, criticisms and assistance in the preparation of the manuscript.

We also wish to express our thanks to Dr O. B. Zaalberg for supplying the rabbitanti-mouse-IgG and to Dr J. M. N. Willers, Dr J. Veldkamp and Dr R. E. Ballieux (University of Utrecht) for supplying the rabbit-anti-mouse-IgA.

This investigation was supported by the Netherlands Foundation for Medical Research (FUNGO).

\section{REFERENCES}

Anderson, H. R. and Oresser, D. W. (1972). 'The long-term distribution of antibody-forming cells.' Europ. F. Immunol., 2, 410.

Askonas, B. A. and Humphrey, J. H. (1958). 'Formation of specific atatibodies and $\gamma$-globulin in vitro. A study of the synthetic ability of various tissues from rabbits immunized by different methods.' Biochem. F., 68, 252.

Askonas, B. A. and White, R. G. (1956). 'Sites of antibody production in the guineampig. The relation between in vitro synthesis of antiovalbumin and $y$ globulin and distribution of antibody-containing plasma cells.' Brit. F. exp. Path., 37, 61.

Askonas, B. A., White, R. G. and Wilkinson, P. C. (1965). 'Production of $\gamma_{1}$-and $\gamma_{2}$-antiovalbumin by various lymphoid tissues of the guinea-pig.' Immunochemistry, 2, 329.

Asofsky, R. M. and Thorbecke, G. J. (1961). 'Sites of formation of immune globulins and of a component of C3. II. Production of immunoelectrophoretically identified serum proteins by human and monkey tissues in vitro.' 7 . exp. Med., 114, 471 .

Chaperon, E. A., Selner, J. C. and Claman, H. N.
(1968). 'Migration of antibody-forming cells and antigen-sensitive precursors between spleen, thymus and bone marrow.' Immtmology, 14, 553 .

Chervenick, P. A., Boggs, D. R., March, J. C., Cartwright, G. E. and Wintrobe, M. M. (1968). 'Quantitative studies of blood and bone marrow neutrophils in normal mice.' Amer. F. Physiol., 215, 353.

CoHen, J. J. (1972). 'Thymus-derived lymphocytes sequestered in the bone marrow of hydrocortisonetreated mice.' 7 . Immunol., 108, 841.

Cunningham, A.J. and Szenserg, A. (1968). 'Further improvements in the plaque technique for detecting single antibody.forming cells.' Immunology, 14, 599.

Erdinger, D. and Pross, H. F. (1967). 'The immune response to sheep erythrocytes in the mouse. I. A study of the immunological events utilizing the plaque technique.' 7 . $\exp$. Med., 126, 15.

Fleming, W. A., Wrikinson, P. C. and Write, R. G. (1967). 'Sites of biosynthesis of immunoglobulins in guinea-pigs immunized with bacteriophage $\phi \mathrm{X} 174$.' Immunology, 13, 613 .

Friedman, H. (1964). 'Distribution of antibody 
plaque-forming cells in various tissues of several strains of mice injected with sheep erythrocytes.' Proc. Soc. exp. Biol. (N.Y.), 117, 526.

Van Furth, R. Schuit, H. R. E. and Hrjmans, W. (1966). 'The formation of immunoglobulins by human tissues in vitro. III. Spleen, lymph nodes, bone marrow, and thymus.' Immunology, 11, 19.

Good, R. A. (1955). 'Studies on agammaglobulinemia. II. Failure of plasma cell formation in the bone marrow and lymph nodes of patients with agammaglobulinemia.' 7 . Lab. clin. Med., 46, 167.

Hrjmans, W. and Schunt, H. R. E. (1972). 'Immunofluorescence studies on immunoglobulins in the lymphoid cells of human peripheral blood.' Clin. exp. Immunol., 11, 483.

Hrjmans, W., Schuit, H. R. E. and Hulsing-Hesselink, E. (1971). 'An immunofluorescence study on intracellular immunoglobulins in human bone marrow cells.' Ann. N.Y. Acad. Sci., 177, 290.

Kolouch, F., Good, R. A. and Campbeli, B. (1947). 'The reticuloendothelial origin of the bone marrow plasma cells in hypersensitive states.' 7. lab. Med. 32,749 .

Langevoort, H. L., Asorskx, R. M., Jacobson, E. B., DE VRIES, T. and Thorbecke, G.J. (1963). 'Gammaglobulin and antibody formation in vitro. II. Parallel observations on histologic changes and on antibody formation in the white and red pulp of the rabbit spleen during the primary response, with special reference to the effect of endotoxin.' $\mathcal{F}$. Immunol., 90,60 .

Lứke, H. (1912). 'Ueber Antikörperbildung in Kulturen lebender Körperzellen.' Berl. klin. Wschr., $49,1034$.

McMillan, R., Longmire, R. L., Yelenosky, R., Lang, J. E., Heath, V. and Craddock, G. G. (1972). 'Immunoglobulin synthesis by human lymphoid tissues: normal bone marrow as a major site of IgG production.' 7. Immunol., 109, 1386.

Mell.bye, O. J. (1971). 'Antibody-producing cells in bone marrow and other lymphoid tissues during the primary immune response in mice.' Int. Arch. Allergy, 40, 248.

Miller, J. F. A. P. (1968). 'Biology of the immune (allergic) response.' Clinical Aspects of Immunology,
Second edn (Ed. by P. G. Gell and R. R. A. Coombs), p. 289. Blackwell Scientific Publications, London.

Mishell, R. I. and Dutton, R. W. (1967). 'Immunization of dissociated spleen cell cultures from normal mice.' 7. exp. Med., 126, 423.

Reiter, H. (1913). 'Studien über Antikörper Bildung in vivo und in Gewebskulturen.' Z. Immun.-Forsch., $18,5$.

Silverman, A. Y., Yagi, Y., Pressman, D., Ellison, R. R. and Tormey, D. C. (1973). 'Monoclonal IgA and IgM in the serum of a single patient (SC). III. Immunofluorescent identification of cells producing IgA and IgM.' 7. Immunol., 110, 350.

Taliaferro, W. H. and Taltaferro, L. G. (1952). 'The role of the spleen and the dynamics of haemolysin production in homologous anamnesis." $f$. infect. Dis., 90, 205.

ThorbECKE, G.J. (1960) 'Gamma globulin and antibody' formation in vitro. Gamma globulin formation in tissues from immature and normal adult rabbits.' $f$. exp. Med., 112, 279.

Thorbecke, G. J., Asofsky, R. M., Hochwald, G. M. and Siskind, G. W. (1962). 'Gammaglobulin and antibody formation in vitro. III. Induction of secondary response at different intervals after the primary; the role of secondary nodules in the preparation for the secondary response.' $\mathcal{J}$. exp. Med., 116, 295.

Thorbecke, G. J. and Keuning, F. J. (1953). 'Antibody formation in vitro by haemopoietic organs after subcutaneous and intravenous immunization.' $\mathcal{J}$. Immunol, , 70, 129.

Thorbecke, G. J. and Keuning, F. J. (1956). "Anti" body and gamma-globulin formation in vitro in haemopoietic organs.' 7 . infect. Dis., 98, 157.

UHR, J. W. and MÖLLER, G. (1968). 'Regulatory effect of antibody on the immune response.' Advances in Immunology. (Ed. by F.J. Dixon and H. G. Kunkel), volume 8, p. 81. Academic Press, New York.

ZaAlberg, O. B., VAN DER Meul, V. A. and Twisk, M. J. (1963). "Antibody production by isolated spleen cells. A study of the cluster and the plaque techniques.' $\mathcal{F}$. Immunol., 100, 451 . 

APPENDIX PUBLICATION II 



\title{
Antibody Formation in Mouse Bone Marrow
}

\section{Evidence for a Memory-Dependent Phenomenon ${ }^{1}$}

\author{
Robbert Benner, Fokke Meima and Gerda M. van der Meulen \\ Department of Cell Biology and Genetics, Erasmus University, Rotterdam, \\ The Netherlands
}

Received December 2, 1973

\begin{abstract}
Mouse bone marrow is barely capable of plaque-forming cell ( $\mathrm{PFC}$ ) activity in a primary response to sheep red blood cells (SRBC), while PFC activity in the secondary response to $\mathrm{SRBC}$ can be clearly demonstrated. This phenomenon was studied by means of cell transfer experiments.

$T$ cells, which are involved in an anti-SRBC PFC response, were shown to be very scarce in normal mouse bone marrow. This is considered to be the cause of the low $\mathrm{PFC}$ activity in the marrow during the primary response to SRBC.

In normal mouse bone marrow precursors of IgM-PFC but not of IgG- and IgAPFC could be found.. Priming with SRBC induced the appearance of IgM-, IgG-, $\operatorname{IgA}$ - and $\mathrm{T}$-memory cells in the marrow. These $\mathrm{B}$ - and $\mathrm{T}$-memory cells were shown to be specific for the antigen which induced their appearance. It is thought that after a second injection of SRBC the IgM-, IgG- and IgA-memory cells can differentiate with the help of the T-memory cells within the bone marrow into IgM-, IgG- and $\mathrm{Ig} A-\mathrm{PFC}$ respectively.

The sequence of appearance of the B-memory cells in the bone marrow was shown to be $\operatorname{Ig} \mathrm{M}-\operatorname{IgG}-\operatorname{Ig} \mathrm{A}$.

Six months after the intravenous injection of $\mathrm{SRBC}$, the presence of $\mathrm{B}$-memory cells could be demonstrated not only in spleen and bone marrow, but also in peripheral lymph nodes, mesenteric lymph node, Peyer's patches, thymus and blood. The increase in amount of B-memory cells was most prominent in the spleen.
\end{abstract}

\section{INTRODUCTION}

In a previous paper (1) it was shown that mouse bone marrow is able to produce plaque-forming cells ( $\mathrm{PFC}$ ) in response to intravenous (iv) injection of sheep red blood cells (SRBC). During the primary response only a few PFC appeared in the marrow. However, in the course of a secondary response the number of PFC in the bone marrow rose to a level which surpassed the level in the spleen. Evidence was presented that this response was caused by a development of PFC in situ.

Transfer experiments reported in the literature $(2-5)$ show that bone marrow cells of nonimmune mice are not able to induce antibody production against SRBC in an irradiated recipient. However, in cooperation with thymocytes a $\mathrm{PFC}$ response against $\mathrm{SRBC}$ can be obtained (3-5). Apparently the bone marrow contains the appropriate $B$ cells, but the necessary $T$ cells are absent. Immunization of the donors evokes an increased number of these $B$ cells which are immunologically specific ( 6 ,

1. This investigation was supported by the Netherlands Foundation for Medical Research (FUNGO). 
7). Other publications report antibody production in irradiated recipients grafted with bone marrow of immunized animals $(2,5,8,9)$. Such observations suggest that the marrow of these donors contained $\mathrm{T}$ cells too.

In the present paper transfer experiments are described which were performed to investigate why the bone marrow contains a considerable number of $\mathrm{PFC}$ in the secondary response, whereas it is hardly capable of producing PFC in the primary response against SRBC. The results suggest that the presence of specific B- and T-memory cells in the bone marrow is required before a PFC response against $\mathrm{SRBC}$ can be initiated in this organ.

\section{MATERIALS AND METHODS}

Mice. $(\mathrm{C} 57 \mathrm{BL} / \mathrm{Rij} \times \mathrm{CBA} / \mathrm{Rij}) \mathrm{F}_{1}$ female mice, 16-20 weeks old were used. They were purchased from the Medical Biological Laboratory, Rijswijk, The Netherlands.

Antigen. Sheep red blood cells were obtained from the Department of Clinical Microbiology of the Erasmus University, Rotterdam, The Netherlands. Horse red blood cells (HRBC) were purchased from the National Institute of Public Health, Bilthoven, The Netherlands.

Immunization. Donor mice were primed with one iv injection of $4 \times 10^{s} \mathrm{SRBC}$. In one experiment this injection was repeated five weeks later.

Preparation of cell suspensions. Cell suspensions were prepared in a balanced salt solution (BSS) (10) as described previously (1). Bone marrow was collected from femora and tibiae. Blood was obtained by cardiac puncture and immediately heparinized $(5 \mathrm{U} / \mathrm{ml})$. Thymocytes were collected $30 \mathrm{~min}$ after an intraperitoneal (ip) injection of the donors with $0.05 \mathrm{ml}$ of a $10 \%$ solution of carbochrome ink (Gurr LTD, High Wycombe, Bucks, England) in BSS. This facilitated differentiation between thymus and adherent lymph nodes in order to avoid contamination of the thymocyte suspension.

Preparation and standardization of anti-theta serum. Anti-theta serum was prepared by injecting $\mathrm{H}-2$ compatible AKR/FuRdA mice (bred in our own colony) with $\mathrm{C}_{3} \mathrm{H} \mathrm{f} / \mathrm{A}$ (purchased from the Laboratory Animals Centre of the Erasmus University, Rotterdam, The Netherlands) thymocytes according to Reif and Allen (11). Cytotoxicity tests and cell transfer experiments indicated that the serum in combination with guinea pig complement (C) was cytotoxic to thymocytes, but not to spleen cells of thymectomized, irradiated and bone marrow reconstituted mice. The serum was standardized on cortisone-resistant thymocytes (Van Muiswinkel, Van Beek and Van Soest, unpublished). These cells were obtained from mice who had received 2 days earlier an ip injection of $30 \mathrm{mg}$ Dexamethasone sodium phosphate (Merck \& Co., Rathway, U.S.A.) per kg body weight. One unit of antitheta serum was the amount necessary to kill $96 \%$ of $10^{6}$ cortisone-resistant thymocytes in the presence of $0.01 \mathrm{ml}$ guinea pig complement.

Antiserum treatment of bone marrow cells. Bone marrow cells were treated for half an hour in melting ice with either anti-theta serum or normal serum from AKR/FuRdA mice (NMS). Three units anti-theta serum per $10^{6}$ bone marrow cells were used. After the incubation the cells were centrifuged and resuspended in BSS and $0.01 \mathrm{ml}$ complement, which was adsorbed previously with mouse spleen cells, was used per $10^{6}$ cells. The cells were incubated for $15 \mathrm{~min}$ at $37^{\circ} \mathrm{C}$, washed three times and resuspended in BSS. 
Cell counts. Viable cells were counted in an haemocytometer using $0.2 \%$ trypan blue in BSS as diluent.

Irradiation. The recipient mice received $850 \mathrm{rad}$ whole body irradiation generated in a Philips Müller MG 300 Xray machine. Animals were irradiated in well-aerated circular Perspex cages. Physical constants of the irradiation were: $250 \mathrm{kV}$ (constant potential); $11 \mathrm{~mA}$; added filtration of $1.0 \mathrm{~mm} \mathrm{Cu}$; irradiation was corrected for field inhomogeneity; focus object distance $53 \mathrm{~cm}$; animals were irradiated at a dose rate of 30-35 rad/min. Maximal backscatter was achieved by placing the cage on a layer of $11 \mathrm{~cm}$ hardboard. During irradiation the dose was measured with a Baldwin Ionex dosimeter. Radiation control mice died in 9-16 days.

Cell transfer. Recipients were injected iv with the appropriate cell suspension and either $5 \times 10^{\mathrm{s}} \mathrm{SRBC}$ or $5 \times 10^{\mathrm{s}} \mathrm{HRBC}$ within $4 \mathrm{hr}$ after irradiation. Recipients inoculated with blood received the thymocytes and SRBC $1 \mathrm{hr}$ after the injection of the blood. On the fourth day all mice were challenged with either $5 \times 10^{3}$ $\mathrm{SRBC}$ or $5 \times 10^{8} \mathrm{HRBC}$ ip. Each group consisted of 5 mice.

Assay for PFC. IgM-, IgG- and IgA-PFC in the spleen of the recipient mice were determined 7 days after cell transfer as described previously (1). The complement used was adsorbed previously with mouse spleen cells and the appropriate red blood cells.

Statistics. Calculation of the $95 \%$ confidence limits associated with the number of plaques counted was done as described in our previous paper (1). The presence of $\operatorname{IgG}-$ and $\operatorname{IgA}-\mathrm{PFC}$ was accepted as significant when there was no overlap between the upper limit in the direct assay and the lower limit in the indirect assay.

\section{RESULTS}

\section{Appearance of B-and T-Memory Cells in the Bone Marrow}

Seven days after transfer of $2 \times 10^{7}$ NMS-treated bone marrow cells of nonimmune mice into lethally irradiated recipients (Group B in Fig. 1) a maximum of only $300 \mathrm{IgM}-\mathrm{PFC}$ could be detected in the recipient spleen. However, in combination with $5 \times 10^{7}$ virgin thymocytes $2 \times 10^{7}$ NMS-treated normal bone marrow cells (Group C in Fig. 1) evoked 18,130 IgM-PFC in the recipient spleen. This finding indicates that in the response against SRBC the T-cell is the limiting factor in mouse bone marrow. Significant numbers of IgG-and IgA-PFC could not be demonstrated after transfer of normal bone marrow alone or in combination with thymocytes. Immunization of the donor mice with $4 \times 10^{s} \mathrm{SRBC}$, increased the capacity of the marrow to cause an anti-SRBC PFC response in the spleen of irradiated recipient mice (Fig. 2). After priming NMS-treated bone marrow cells were capable of evoking an IgM-, as well as an IgG- and IgA-PFC response in the recipient spleen beyond the third week, indicating that B-memory cells appeared in the marrow. Addition of $5 \times 10^{7}$ virgin thymocytes (Group C in Fig. 1) enhanced the response up to two times, whereas prior treatment of the marrow cells with anti-theta serum and complement (Group A in Fig. 1) reduced the response to about $5 \%$. These results indicate that these $\mathrm{B}$-nemory cells are thymus-dependent and that T-memory cells must be present at 3 weeks after priming in the marrow of immunized mice. About 14 weeks after priming the amount of memory cells in the marrow reached a plateau. 


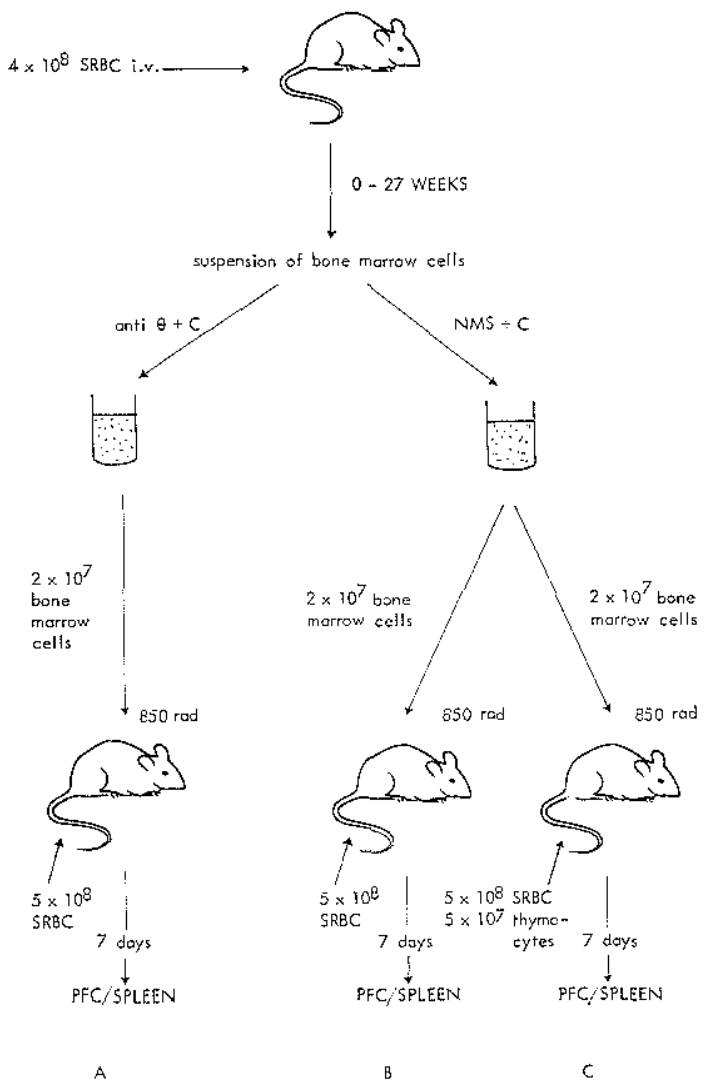

FIG. 1. Scheme of the experimental set-up used to determine the presence of $B$ ancl ' $T$ ' cells in the bone marrow before and various times after an iv injection of $4 \times 10^{\mathrm{s}} \mathrm{SRBC}$.

In order to determine whether or not the B- and T-memory cells in the bone marrow are specific for the priming antigen, bone marrow cells of donors primed 5 weeks before with $4 \times 10^{8} \mathrm{SRBC}$, were transferred into lethally irradiated recipients. Before transfer one part of the bone marrow suspension was treated with anti-theta serum and complement in vitro, and the other part with NMS and complement in vitro. As it appears in Table $1,2 \times 10^{7}$ NMS-treated bone marrow cells of mice primed with SRBC evoked an increased number of $\mathrm{PFC}$ against $\mathrm{SRBC}$ but not to HRBC. So the T-memory cells are specific for the priming antigen. NMS-treated bone marrow cells $\left(2 \times 10^{7}\right)$ of SRBC-primed mice in combination with $5 \times 10^{i}$ thymocytes did not evoke increased numbers of $\mathrm{PFC}$ against $\mathrm{HRBC}$ as compared with $2 \times 10^{7} \mathrm{NMS}$-treated bone marrow cells of nonimmune mice in combination with $5 \times 10^{7}$ thymocytes. Thus the IgM-, IgG- and IgA-memory cells are also specific for the antigen which induced them.

The sequence of the appearance of the B-memory cells of the main classes of immunoglobulins in the bone marrow was studied in another experiment. At various times after priming of the donor mice $2 \times 10^{7}$ bone marrow cells were combined with $5 \times 10^{7}$ virgin thymocytes and $5 \times 10^{8} \mathrm{SRBC}$ and transferred into irradiated recipients. From the 7 th day after priming of the donor mice the bone 

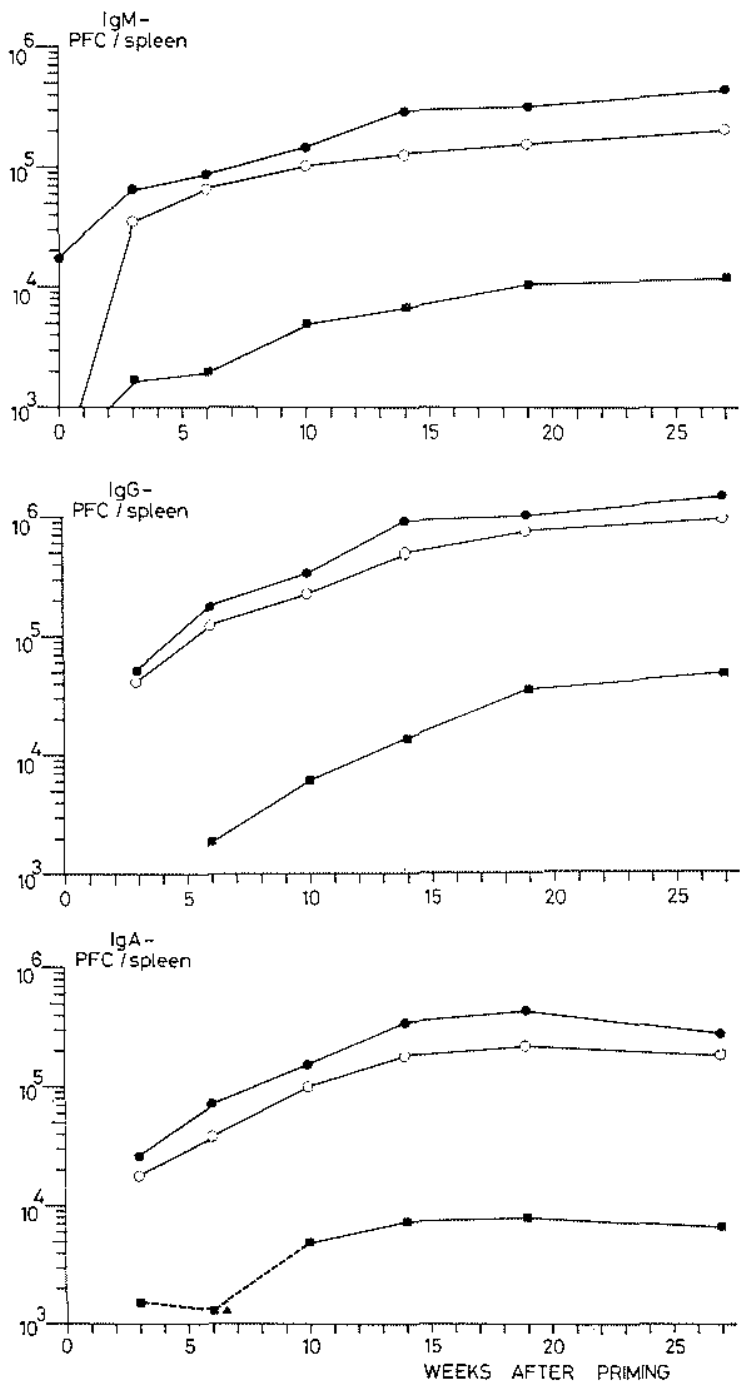

FIG. 2. PFC responses of the spleens of lethally irradiated mice receiving $2 \times 10^{7}$ bone marrow cells from donors primed iv with $4 \times 10^{8} \mathrm{SRBC}$ various times before cell transfer. The responses are given of mice receiving bone marrow cells pretreated with anti-theta serum ( $)$, pretreated with NMS (O), and NMS-pretreated bone marrow cells combined with $5 \times 10^{7}$ virgin thymocytes (-). Addition of $(\boldsymbol{A})$ to a square means that the number of PFC in the indirect assay did not differ significantly from the number of PFC in the direct assay. At the beginning of the experiment the bone marrow cells in combination with thymocytes could not evoke significant numbers of IgG- and IgA-PFC. Each point is a mean value obtained from 5 mice.

marrow cells evoked increased numbers of IgM-PFC in the spleen of the recipient mice (Fig. 3). In the recipient spleen significant numbers of IgG-PFC could be detected at the 14th day and significant numbers of IgA-PFC could be detected at the 21 st day after priming of the donor mice. Thus the sequence in appearance of B-memory cells in the bone marrow is $\operatorname{Ig} M-\operatorname{IgG}-\operatorname{IgA}$. 
TABLE

Anti-SRbC and Anti-HRbC PFC Rlisponse in the Spleen of Recipient Mice Inoculated With Bone Makrow Cells in Combination With SRBC and HRBC Respectively

\begin{tabular}{|c|c|c|c|c|c|c|c|}
\hline \multirow[t]{2}{*}{ Treatment in vitro } & \multirow[t]{2}{*}{ Thymus Cells } & \multicolumn{3}{|c|}{ Anti-SRBC PFC/spleen ${ }^{a}$} & \multicolumn{3}{|c|}{ Anti-HRBC PFC/splecn ${ }^{n}$} \\
\hline & & $\operatorname{Ig} \mathrm{M}$ & $\operatorname{IgG}$ & $\operatorname{Ig} A$ & $\operatorname{Ig} M$ & IgG & IgA \\
\hline \multicolumn{8}{|c|}{ Marrow Donors NonImnune } \\
\hline Anti-theta $+C$ & - & 275 & 80 (n.s.) ${ }^{b}$ & 160 (n.s.) & 270 & 25 (n.s.) & 0 (n.s.) \\
\hline $\mathrm{NMS}+\mathrm{C}$ & - & 975 & 400 (n.s.) & 100 (n.s.) & 2,675 & 0 (n.s.) & 250 (n.s.) \\
\hline $\mathrm{NMS}+\mathrm{C}$ & $5 \times 10^{7}$ & 33,400 & 5,600 (n.s.) & 6,600 (n.s.) & 31,600 & 9,600 (n.s.) & 0 (n.s.) \\
\hline \multicolumn{8}{|c|}{ Marrow Donors Immunized With $4 \times 10^{8} \mathrm{SRBC}$ iv } \\
\hline Anti-theta $+\mathrm{C}$ & - & 1,200 & 1,325 & 875 (n.s.) & 120 & 25 (n.s.) & 10 (n.s.) \\
\hline $\mathrm{NMS}+\mathrm{C}$ & - & 52,000 & 74,500 & 25,500 & 2,425 & 600 (n.s.) & 1,400 (n.s.) \\
\hline $\mathrm{NMS}+\mathrm{C}$ & $5 \times 10^{7}$ & 63,500 & 95,500 & 27,250 & 25,300 & 1,150 (n.s.) & 2,200 (r.s.) \\
\hline
\end{tabular}

${ }^{a}$ Each recipient mouse received $2 \times 10^{7}$ viable nucleated bone marrow cells after treatment with either anti-theta scrum and complement or NMS and com. plement in vitro. Each group consisted of 5 recipient mice. $\mathrm{PFC}$-assay was done on pooled spleens 7 days after cell transfer.

${ }^{b}$ There was no significant difference between the number of PFC in the direct assay and the number of PFC in the indirect assay. 


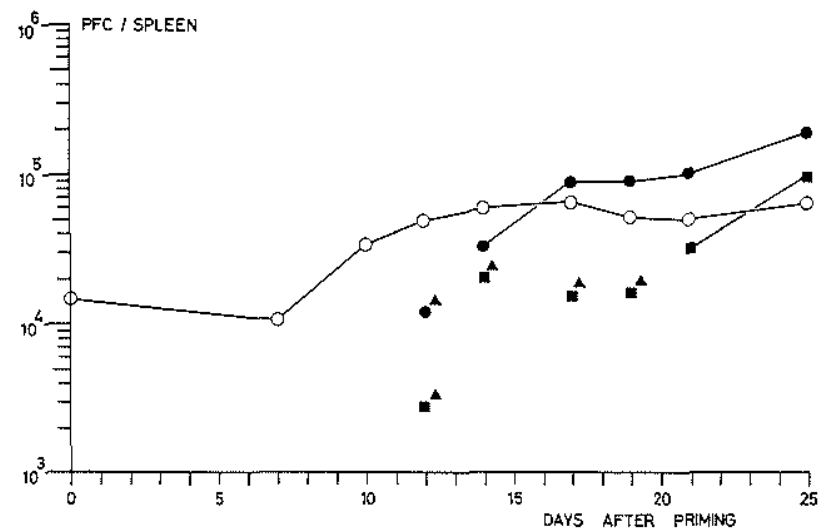

FIg. 3. PFC responses of the spleens of lethally irradiated mice receiving $2 \times 10^{7}$ bone marrow cells from donors primed iv with $4 \times 10^{\mathrm{s}} \mathrm{SRBC}$ at various times before cell transfer. Bone marrow cells were always supplemented with $5 \times 10^{?}$ virgin thymocytes. Each point is a mean value obtained from 5 mice. (O), IgM-PFC; (•), IgG-PFC; (曰), IgA-PFC; addition of $(\boldsymbol{\Delta})$ to a closed circle or square means that the number of PFC in the indirect assay differed not significantly from the number of PFC in the direct assay.

\section{Distribution of B-memory Cells in Various Lymphoid Organs}

The distribution of B-memory cells 27 weeks after immunization was studied by transferring fixed numbers of nucleated cells of various lymphoid organs together with $5 \times 10^{7}$ virgin thymocytes and $5 \times 10^{8}$ SRBC into lethally irradiated recipients. To describe the amount of precursors of PFC ( $\mathrm{PPFC}$ ) of an organ quantitatively, the conception "PFC capacity" was introduced and defined as

number of cells in the organ

number of cells transferred into the recipient

$X$ mean number of $\mathrm{PFC}$ per recipient spleen.

To calculate the increase in the amount of $\mathrm{pPFC}$ caused by an iv injection of $4 \times 10^{8}$ SRBC, the PFC capacity of various lymphoid organs 27 weeks after priming was compared with the $\mathrm{PFC}$ capacity of the organs of nonimmune mice of the same age. Table 2 shows that cells of spleen, bone marrow, peripheral lymph nodes (inguinal, axillary and brachial), mesenteric lymph node, Peyer's patches (only patches of the small intestine were used) and blood of the nonimmune mice were able to evoke a PFC response in the recipient spleen. Except for bone marrow and Peyer's patches cells of all these organs provoked not only IgM- and IgG-PFC, but also IgA-PFC. Transfer of thymocytes did not result in significant numbers of PFC in the recipient spleen. The PFC capacity of the spleen was the greatest of all the organs tested. In a similar experiment with lymphoid cells from mice which had been immunized 27 weeks previously with an iv injection of $4 \times 10^{8}$ SRBC, thymus, in addition to spleen, bone marrow, peripheral lymph nodes, mesenteric lymph node, Peyer's patches and blood, was able to evoke a PFC response in the recipient spleen (Table 3 ). The cells of all these organs gave rise to IgM- and IgGas well as IgA-PFC in the recipient spleen. Comparison of Table 2 and Table 3 shows that immunization of the donor mice caused an increase in PFC capacity of all the organs tested. Table 4 shows the increase in PFC capacity of the various 
TABLE 2

PFC Capacity of Various Lymphoid Organs of Nonimmune Mice

\begin{tabular}{|c|c|c|c|c|c|c|c|}
\hline \multirow[t]{2}{*}{ Cells transferred from: } & \multirow{2}{*}{$\begin{array}{l}\text { Cells/organ } \\
\left(\times 10^{7}\right)\end{array}$} & \multicolumn{3}{|c|}{$\mathrm{PFC} /$ spleen $\left(\times 10^{3}\right)^{a}$} & \multicolumn{3}{|c|}{ PFC capacity $\left(\times 10^{3}\right)^{b}$} \\
\hline & & $\operatorname{Ig} \mathrm{M}$ & $\operatorname{IgG}$ & $\operatorname{IgA}$ & $\lg M$ & $\operatorname{IgG}$ & $\operatorname{Ig} A$ \\
\hline Spleen & 11.4 & 441 & 1,464 & 227 & 2,512 & 8,347 & 1,293 \\
\hline Bone marrow & $33.6^{c}$ & 32 & 80 & 11 (n.s.) ${ }^{d}$ & 529 & 1,348 & 189 (n.s.) \\
\hline Peripheral lymph nodes ${ }^{e}$ & 1.4 & 360 & 1,883 & 167 & 252 & 1,318 & 117 \\
\hline Mesenteric lymph node & 1.9 & 773 & 2,673 & 456 & 734 & 2,540 & 433 \\
\hline Peyer's patches ${ }^{f}$ & 1.8 & 584 & 642 & 110 (n.s.) & 525 & 578 & 99 (n.s.) \\
\hline Thymus & 3.7 & 0.3 & 0 & 0 & 0.5 & 0 & 0 \\
\hline Blood & $2.5 \mathrm{ml}^{\theta}$ & 7 & 15 & 7 & 37 & 76 & 34 \\
\hline
\end{tabular}

a Viable nucleated cells $\left(2 \times 10^{7}\right)$ or $0.5 \mathrm{ml}$ blood were transferred 27 weeks after the beginning of the experiment together with $5 \times 10^{7}$ isologous thymocytes of nonimmune 5 week old female mice. Each group consisted of 5 recipient mice. PFC-assay was done on pooled spleens 7 days after cell transfer.

${ }^{b}$ For definition see Results.

- Calculation based upon data of Chervenick et al. (44).

${ }^{d}$ There was no significant difference between the number of $\mathrm{PFC}$ in the direct assay and the number of $\mathrm{PFC}$ in the indirect assay.

${ }^{e}$ Inguinal, axillary and brachial lymph nodes were used.

$f$ Only the patches of the small intestine were used.

s Estimated volume per mouse.

organs 27 weeks after an iv injection of $4 \times 10^{8}$ SRBC. It appears that by far the greatest increase in PFC capacity was found in the spleen.

A second iv injection of $4 \times 10^{8}$ SRBC 5 weeks after the first one did not further increase the PFC capacity of spleen and bone marrow (Table 5). Addition

TABLE 3

PFC Capacity of Various Lymphotd Organs After One iv Injection of $4 \times 10^{8} \mathrm{SRBC}$

\begin{tabular}{|c|c|c|c|c|c|c|c|}
\hline \multirow[t]{2}{*}{ Cells transferred from: } & \multirow{2}{*}{$\begin{array}{l}\text { Cells/organ } \\
\left(\times 10^{7}\right)\end{array}$} & \multicolumn{3}{|c|}{$\mathrm{PFC} /$ spleen $\left(\times 10^{3}\right)^{a}$} & \multicolumn{3}{|c|}{ PFC capacity $\left(\times 10^{3}\right)^{b}$} \\
\hline & & $\operatorname{IgM}$ & $\operatorname{IgG}$ & $\operatorname{Ig} A$ & $\operatorname{IgM}$ & $\operatorname{IgG}$ & $\operatorname{Ig} A$ \\
\hline Spleen & 10.9 & 7,273 & 32,350 & 6,018 & 39,638 & 176,308 & 32,798 \\
\hline Bone marrow & $31.4^{c}$ & 428 & 1,801 & 413 & 6.720 & 28,276 & 6,484 \\
\hline Peripheral lymph nodes ${ }^{d}$ & 1.6 & 1,290 & 15,998 & 2,750 & 1,032 & 12,798 & 2,200 \\
\hline Mesenteric lymph node & 2.1 & 2,250 & 22,838 & 3,600 & 2,362 & 23,980 & 3,780 \\
\hline Peyer's patches ${ }^{e}$ & 1.1 & 1,621 & 6,973 & 2,547 & 892 & 3,835 & 1,401 \\
\hline Thymus & 3.1 & 13 & 107 & 35 & 20 & 166 & 54 \\
\hline Blood & $2.5 \mathrm{ml}^{f}$ & 4 & 95 & 8 & 20 & 475 & 39 \\
\hline
\end{tabular}

${ }^{a}$ Viable nucleated cells $\left(2 \times 10^{7}\right)$ or $0.5 \mathrm{ml}$ blood were transferred 27 weeks after immunization of the donor mice together with $5 \times 10^{7}$ isologous thymocytes of nonimmune 5 week old female mice. Each group consisted of 5 recipient mice. PFC-assay was done on pooled spleens 7 days after cell transfer.

${ }^{\circ}$ For definition see Results.

c Calculation based upon data of Chervenick et al. (44).

${ }^{d}$ Inguinal, axillary and brachial lymph nodes were used.

c Only the patches of the small intestine were used.

$f$ Estimated volume per mouse. 
TABLE 4

Increase in PFC Capacity After One iv Injection of $4 \times 10^{8} \mathrm{SRBC}\left(\times 10^{3}\right)$

\begin{tabular}{lrrr}
\hline & IgM-PFC $^{a}$ & IgG-PFC $^{a}$ & IgA-PFC $^{a}$ \\
\cline { 2 - 4 } Spleen & 37,126 & 167,961 & 31,505 \\
Bone marrow & 6,191 & 26,928 & 6,295 \\
Peripheral lymph nodes & 780 & 11,480 & 2,083 \\
Mesenteric lympl node & 1,628 & 21,440 & 3,347 \\
Peyer's patches & 367 & 3,257 & 1,302 \\
Thymus & 19 & 166 & 54 \\
Blood & -13 & 399 & 5 \\
\hline
\end{tabular}

a. The number of $\mathrm{PFC}$ are obtained by subtracting the respective numbers of $\mathrm{PFC}$ in Table 2 from those in Table 3.

of $5 \times 10^{-}$virgin thymocytes to spleen and bone marrow cells did not enhance the $\mathrm{PFC}$ response of the recipient spleen markedly. Thus the number of $T$ cells in these organs is not a limiting factor in this case.

\section{DISCUSSION}

The results presented in this paper demonstrate that after iv immunization with SRBC B- (IgM-, IgG-, IgA-) and T-memory cells appear in the bone marrow (Fig. 2). These B- and T-memory cells are specific for the antigen used for priming (Table 1). Differentiation of B-memory cells into PFC need the help of $T$ cells, because prior treatment of the marrow cells with anti-theta serum and complement in vitro resulted in a much lower response in the spleen of the irradiated recipients. It is worth noting that the inhibiting effect of the anti-theta treatment upon the IgM-, IgG- and IgA-PFC response against SRBC is about equal for all these categories. This is not in agreement with the literature about the thymic-dependence of immunoglobulin production, because IgM response is thought to be less thymus-dependent than IgG response (12-15). The literature about the thymic-dependence of IgA production is contradictory (13-15). On ac-

TABLE 5

PfC Capacity of Spleen and Bone Marrow After Two iv Injections of $4 \times 10^{8} \mathrm{SRBC}$

\begin{tabular}{|c|c|c|c|c|c|c|c|c|}
\hline \multirow{2}{*}{$\begin{array}{l}\text { Cells trans- } \\
\text { ferred from: }\end{array}$} & \multirow{2}{*}{$\begin{array}{c}\text { Cells/ } \\
\text { organ } \\
\left(\times 10^{7}\right)\end{array}$} & \multirow{2}{*}{$\begin{array}{l}\text { Thymus } \\
\text { cells }\end{array}$} & \multicolumn{3}{|c|}{$\mathrm{PFC} /$ spleen $\left(\times 10^{3}\right)^{a}$} & \multicolumn{3}{|c|}{ PFC capacity $\left(\times 10^{3}\right)^{b}$} \\
\hline & & & $\lg M$ & IgG & $\operatorname{Ig} A$ & $\operatorname{Ig} \mathrm{M}$ & $\operatorname{IgG}$ & $\operatorname{Ig} A$ \\
\hline Spleen & 12.0 & - & 2,175 & 26,314 & 2,307 & 13,050 & 157,884 & 13,842 \\
\hline Spleen & 12.0 & $5 \times 10^{7}$ & 1,944 & 29,860 & 2,911 & 11,664 & 179,160 & 17,466 \\
\hline Bone marrow & $35.9^{c}$ & - & 356 & 1,823 & 390 & 6,390 & 32,723 & 7,001 \\
\hline Bone marrow & $35.9^{c}$ & $5 \times 10^{7}$ & 391 & 2,403 & 452 & 7,018 & 43,134 & 8,113 \\
\hline
\end{tabular}

${ }^{a}$ Donor mice received the second iv injection of $4 \times 10^{8}$ SRBC 5 weeks after the first. Viable nucleated cells $\left(2 \times 10^{7}\right)$ were transferred 27 weeks after the first injection of SRBC together with $5 \times 10^{7}$ isologous thymocytes of nonimmune 5 week old female mice. Each group consisted of 5 recipient mice. PFC-assay was done on pooled spleens 7 days after cell transfer.

${ }^{b}$ For definition see Results.

- Calculation based upon data of Chervenick et al. (44). 
count of our results we conclude that the development of $\operatorname{IgA-PFC}$ is thymusdependent to a large extent. Other cell transfer experiments performed in this laboratory demonstrate that the development of IgA-PFC from B cells of nonimmune mice also requires collaboration with $\mathrm{T}$ cells (Van Muiswinkel and Van Soest, unpublished). The question arises whether the PFC response of the recipient mice inoculated with anti-theta treated bone marrow cells is a consequence of the presence of a subpopulation of entirely thymus-independent B cells or is due to an incomplete abolishment of $\mathrm{T}$ cells by the anti-theta serum. Although a great excess of antitheta serum was used in our experiments, survival of some theta-positive cells can not be excluded, since $T$ cells lose a part of their theta-antigen during maturation (16-18).

The B-memory cells of the different major classes of immunoglobulins were demonstrated to appear in the bone marrow in the sequence IgM-IgG-IgA (Fig. 3). The same sequence has been described with regard to phylogeny (19), ontogeny (20-23), appearance of B lymphocytes after bone marrow reconstitution of lethally irradiated mice (Van Muiswinkel, Van Beek and Van Soest, unpublished), appearance of immunoglobulins in the serum of patients with a severe combined immunodeficiency after bone marrow transplantation $(24,25)$, and antibody production $(1,26,27)$.

Comparison of the results presented here with those in our previous paper (1) shows that the absence of the necessary $T$ cells in the bone marrow coincides with the absence of a clear PFC response in situ after primary iv immunization with SRBC. The presence of IgM-, IgG-, IgA- and T-memory cells in the bone marrow coincides with the presence of a clear IgM-, IgG- and IgA-PFC response in situ after an iv boosting injection. Therefore we conclude that antibody formation against SRBC in mouse, is dependent on the presence of B-and T-memory cells.

Analysis of the PFC capacity (see Results for definition) in the different organs before (Table 2) and 27 weeks after (Table 3 ) a single iv injection of SRBC reveals that such an immunization results in an increased PFC capacity of spleen, bone marrow, peripheral lymph nodes, mesenteric lymph node, Peyer's patches, thymus and blood (Table 4). It is somewhat surprising that 27 weeks after the beginning of the experiment the marrow of the nonimmune mice combined with virgin thymocytes was capable of an IgM- as well as an IgG-PFC response (Table 2 ), whereas at the beginning only an IgM-PFC response could be demonstrated (Fig. 2). Possibly a continuous stimulation by Forssmann antigens in the intestine $(28,29)$ is the underlying cause. Comparison of the PFC capacity of spleen and bone marrow after two iv injections of SRBC (Table 5) with the results presented in our previous paper (1) shows a very peculiar discrepancy: late in the secondary response against SRBC the bone marrow contains much more PFC than the spleen, whereas the PFC capacity of the spleen is by far the greatest (Table 5). This can not be a consequence of a lack of T-memory cells because addition of $5 \times 10^{7}$ thymocytes hardly enhanced the PFC capacity (Table 5). Probably the differentiation of $\mathrm{pPFC}$ into $\mathrm{PFC}$ in the late phase of the secondary response in the bone marrow is greatly facilitated for some reason.

The results presented here and in our previous paper (1) seem to be relevant with regard to the experiments of McMillan et al. (30) and Hijmans et al. (31, 32). McMillan et al. demonstrated that human bone marrow cells cannot be stimulated in vitro to antibody production against smallpox vaccine. However, in their 
experiments human bone marrow cells appeared to be able to produce large amounts of IgG in vitro. Hijmans et al. presented evidence that in healthy people the bone marrow is a major source of immunoglobulins. We suggest that in these observations the immunoglobulins could be produced by the progeny of $\mathrm{B}$ (memory) cells against antigens continuously stimulating the lymphoid organs, for example intestinal bacteria.

The appearance of B-memory cells in the thymus after iv immunization is remarkable (Table 3 ). This observation is consistent with the results of others using different experimental procedures $(5,9,33-35)$. It is of interest to investigate whether or not these B cells behave like the other thymocytes. Experiments reveal that these B-memory cells are not influenced by dexamethasone-treatment in vivo and by anti-theta treatment in vitro (Benner, Meima and Van der Meulen, unpublished).

It has been reported that injection of an antigen into the thymus evokes the development of lymphoid follicles with germinal centers (36-38) and antibody production $(36,38,39)$ in situ. The germinal center reactions are thought to be involved in the development of B-memory cells $(40-42)$. In our experiments the appearance of B-memory cells in the thymus can be due either to the entrance of the antigen into the thymus or to an influx of B-memory cells.

In conclusion it can be said that 27 weeks after an iv injection of SRBC the presence of B-memory cells can be demonstrated in the spleen, bone marrow, peripheral lymph nodes, mesenteric lymph node, Peyer's patches, thymus and the blood. Evidence is presented that the appearance of specific B- and T-memory cells in the bone marrow is required for the development of PFC in situt.

\section{ACKNOWLEDGMENTS}

We are very indebted to Prof. Dr. O. Vos, Dr. W. Hijmans (Institute for Experimental Gerontology, Rijswijk, The Netherlands), Dr. O. B. Zaalberg (The Medical Biological Laboratory, Rijswijk, The Netherlands) and Dr. J. M. N. Willers (University of Utrecht, The Netherlands) for helpful suggestions, criticisus and assistance in the preparation of the manuscript.

We also express our thanks to Dr. O. B. Zaalberg for supplying the rabbit anti-mouse-IgG and to Dr. J. Veldkamp (National Institute of Public Health, Bilthoven, The Netherlands) for supplying the rabbit anti-mouse-Ig $A$.

The excellent technical assistance of Mr. J. Rozing is gratefully acknowledged.

\section{REFERENCES}

1. Benner, R., Meima, F., van der Meulen, G. M., and van Muiswinkel, W. B., Immunology. 26, 247, 1974.

2. Gengozian, N., Makinodan, T., and Shekarchi, I. C. J. Inmunol. 86, 113, 1961.

3. Claman, H. N., Chaperon, E. A., and Triplett, R. F., Proc. Soc. Exp. Biol. Mcd. 122, 167, 1966.

4. Witchell, G. F., and Miller, J. F. A. P., J. Exp. Med. 128, 821, 1968.

5. Jehn, U. W., and Karlin, L., J. Immunol. 106, 946, 1971.

6. Miller, H. C., and Cudkowicz, G., J. Exp. Med. 133, 973, 1971.

7. Miller, H. C., and Cudkowicz, G., J. Exp. Med. 135, 1028, 1972.

8. Stoloff, I. L. J. Immmol. 85, 304, 1960.

9. Stoner, R. D., and Bond, V. P., J. Immunol. 91, 185, 1963.

10. Mishell, R. I., and Dutton, R. W., J. Exp. Med. 126, 423, 1967.

11. Reif, A. E., and Allen, J. M., Nature (London) 209, 521, 1966.

12. Taylor, R. B., and Wortis, H. H., Nature (London) 220, 927, 1968. 
13. Torrigiani, G., J. Immunol. 108, 161, 1972.

14. Pritchard, H., Riddaway, J., and Micklem, H. S., Clin. Exp. Immmol. 13, 125, 1973.

15. Bloemmen, J., and Eyssen, H., Eur. J. Immunol. 3, 117, 1973.

16. Bryant, B. J., J. Immunol. 107, 1791, 1971.

17. Miller, J. F. A. P., and Sprent, J., Nature Nere Biol. 230, 267, 1971.

18. Raff, M. C., and Cantor, H., In "Progress in Immunology" (B. Amos, Ed.), pp. 83-93. Academic Press, New York, 1971.

19. Good, R. A., In "Immunobiology" (R. A. Good and D. W. Fisher, Eds.), pp. 3-16. Sinauer Associates, Inc., Stanford, Connecticut, 1971.

20. van Furth, R., Schuit, H. R. E., and Hijmans, W., J. Exp. Med. 122, 1173, 1965

21. Kincade, P. W., and Cooper, M. D., J. Immunol. 106, 371, 1971.

22. Lawton, A. R., Self, K. S., Royal, S. A., and Cooper, M. D., Clin. Immunol. Immunopathol. $1,84,1972$.

23. Martin, L. N., and Leslie, G. A., Proc. Soc. Exp. Biol. Med. 143, 241, 1973.

24. Rádl, J., Dooren, L. J., Eijsvoogel, V. P., van Went, J. J., and Hijmans, W., Clin. Exp. lmmunol. 10, 367, 1972.

25. Vossen, J. M., de Koning, J., van Bekkum, D. W., Dicke, K. A., Eijsvoogel, V. P., Hijmans, W., van Loghem, E., Rádl, J., van Rood, J. J., van der Waay, D., and Dooren, L. J., Clin. Exp. Immunol. 13, 9, 1973.

26. Wortis, H. H., Dresser, D. W., and Anderson, H. R., Immunology. 17, 93, 1969.

27. Bluestein, H. G., and Pierce, C. W., J. Immunol. 111, 130, 1973.

28. Boyd, W. C., "Fundamentals of Immunology." Interscience Publ., New York, 1966.

29. Cheng, V., and Trentin, J. J., Proc. Soc. Exp. Biol. Med. 126, 467, 1967.

30. McMillan, R., Longmire, R. L., Yelenosky, R., Lang, J. E., Heath, V., and Craddock, C. G., J. Inmunol. 109, 1386, 1972.

31. Hijmans, W., Schuit, H. R. E., and Hulsing-Hesselink, E., Ann. N.Y. Acad. Sci. 177, $290,1971$.

32. Hijmans, W., and Schuit, H. R. E., Clin. Exp. Immunol. 11, 483, 1972.

33. Stoner, R. D., and Hale, W. M., J. Immunol. 75, 203, 1955.

34. Dixon, F. J., Weigle, W. O., and Roberts, J. C., J. Immunol. 78, 56, 1957.

35. Thorbecke, G. J., and Cohen, M. W., In "The Thymus" (V. Defendi and D. Metcalf, Eds.), pp. 33-40. Wistar Institute Press, Philadelphia, 1964.

36. Marshall, A. H. E., and White, R. G., Brit. J. Exp. Path. 42, 379, 1961.

37. Sherman, J. D., Adner, M. M., and Dameshek, W., Proc. Soc. Exp. Biol. Med. 115, 866, 1964.

38. Habu, S., Acta Path. Jap. 22, 681, 1972.

39. Jokipii, A. M. M., Ann. Med. Exp. Biol. Fenn. 49, 176, 1971.

40. Thorbecke, G. J., In "Lymphatic tissue and germinal centers in immune response" (L. Fiore-Donati and M. G. Hanna, Eds.), pp. 83-92, Plenum Press, New York, 1969.

41. Durkin, H. G., and Thorbecke, G. J., J. Immunol. 106, 1079, 1971.

42. Nieuwenhuis, P., Thesis, Groningen, The Netherlands, 1971.

43. Chervenick, P. A., Boggs, D. R., Marsh, J. C., Cartwright, G. E., and Wintrobe, M. M., Amer. J. Physiol. 215, 353, 1968. 
APPENDIX PUBLICATION III 


\title{
Antibody Formation in Mouse Bone Marrow
}

\section{EFFECTS OF ROUTE OF PRIMING AND ANTIGEN DOSE}

\author{
R. Benner, F. Meima, Gerda M. Van der Meulen and W. van Ewijk \\ Department of Cell Biology and Genetics, Erasmus University, P.O. Box 1738, Rotterdam, \\ The Netherlands
}

(Received 1st March 1974; accepted for publication 19th March 1974)

Summary. The influence of the route of priming and the dose of sheep red blood cells (SRBC) on the IgM-, IgG- and IgA-plaque-forming cell (PFC) activity in mouse bone marrow during the secondary response to $\mathrm{SRBC}$ was studied. After intraperitoneal and subcutaneous priming the number of IgM-, IgG- and IgA$\mathrm{PFC}$ during the secondary response increased with the number of SRBC used for priming. After intravenous (i.v.) priming the priming dose-secondary response relationship was found to be an optimum curve for IgM-PFC as well as for IgGand IgA-PFC. A peak secondary response in the bone marrow was found after priming with $10^{7}$ and with $10^{8}$ SRBCi.v.

The appearance of IgG- and IgA-memory cells in the bone marrow after i.v. immunization with SRBC was shown to be dependent on the priming dose: the appearance of IgG-memory cells required a higher dose of SRBC than the appearance of IgM-memory cells, and the appearance of IgA-memory cells required even more antigen.

The effect of the booster dose upon the PFC activity was studied in mice primed with $10^{7} \mathrm{SRBC}$ i.v. and boosted with $10^{4}, 10^{6}$, or $10^{9} \mathrm{SRBC}$ i.v. 2 months later. IgM-PFC as well as IgG- and IgA-PFC were present in spleen and bone marrow at each booster dose tested. In each group of mice the PFC activity in the bone marrow rose to a level which surpassed the level in the other lymphoid organs between the 7 th and 10th day after the booster injection. Thus, independently of the booster dose, mouse bone marrow is the major source of PFC during the late phase of the secondary response to SRBC. Mice boosted with $10^{9} \mathrm{SRBC}$ i.v. showed a prolonged presence of IgM-, IgG- and IgA-PFC in the thymus. Light and electron microscopic studies revealed the presence of plasma cells and macrophages studded with phagocytosed material in the thymic medulla of these mice, thus providing evidence for a real PFC response within the thymus. A thymic PFG response was absent in mice boosted with either $10^{4}$ or $10^{6} \mathrm{SRBC}$ i.v. Therefore the thymic $\mathrm{PFC}$ activity during the secondary response to SRBC does depend on the booster dose.

\section{INTRODUCTION}

In previous studies it has been shown that mouse bone marrow is barely capable of Correspondence: Dr R. Benner, Department of Cell Biology and Genetics, Erasmus University, P.O. Box 1738, Rotterdam, The Netherlands. 
producing plaque-forming cells $(\mathrm{PFC})$ in the primary immune response to sheep red blood cells (SRBC), whereas in the secondary response to SRBC bone marrow PFC can be clearly demonstrated (Benner, Meima, Van der Meulen and Van Muiswinkel, 1974a). Evidence was presented that the PFC activity of the bone marrow in the secondary response is caused by the development of PFG in situ (Benner et al., 1974a). Cell transfer experiments suggest that the presence of specific $\mathrm{B}$ and $\mathrm{T}$ memory cells in the bone marrow is required before a $\mathrm{PFC}$ response against $\mathrm{SRBC}$ can be initiated in this organ (Benner, Meima and Van der Meulen, 1974b). The absence of appropriate memory cells is considered to be the cause of the low PFC activity in the marrow during the primary response to SRBC.

From the data presented previously (Benner et al., 1974a) it cannot be excluded that $\mathrm{PFC}$ activity in the bone marrow during the secondary response is a rather extraordinary (nonphysiological) phenomenon attributable to the high doses of SRBC used in these studies. In the present paper data will be presented which suggest that during the secondary response to $\mathrm{SRBC}$ (a) the presence of $\mathrm{PFC}$ in the bone marrow is independent of the booster dose and (b) the presence of $\mathrm{PFC}$ in the thymus does depend on the booster dose. Furthermore, the effects of dose and route of priming upon the PFC activity in the bone marrow during the secondary response to SRBC will be discussed.

\section{MATERIALS AND METHODS}

\section{Mice}

$(\mathrm{C} 57 \mathrm{Bl} / \mathrm{Rij} \times \mathrm{CBA} / \mathrm{Rij}) \mathrm{F}_{1}$ female mice, 16-20 weeks old were used. They were purchased from the Medical Biological Laboratory, Rijswijk, The Netherlands.

Antigen

SRBC were obtained from the Department of Clinical Microbiology of the Erasmus University, Rotterdam, The Netherlands.

\section{Immunization}

For primary immunization, mice received either an intravenous (i.v.), intraperitoneal (i.p.) or subcutaneous (s.c.) injection of SRBC. In all experiments the second injection of SRBC was given i.v. The interval between first and second antigen injection was 2 or 3 months.

\section{Splenectomy}

Splenectomy was performed either 1 day or 1 month before the second injection of SRBC. Mice were anaesthetized by an i.p. injection of $70 \mathrm{mg} / \mathrm{kg}$ body weight Nembutal (Abbott S. A., Saint-Rémy-sur-Avre, France). The incision was made in the left upper abdomen. The splenic vessels were tied in a single suture, then cut and the spleen removed. The incision was closed in two layers. There was no post-operative mortality.

\section{Preparation of cell suspensions}

Cell suspensions were prepared in a balanced salt solution (BSS) as described previously (Benner et al., 1974a). The BSS was prepared according to Mishell and Dutton (1967) and always supplemented with 5 per cent newborn calf serum. Thymocytes were collected 30 minutes after an i.p. injection of the donors with $0.05 \mathrm{ml}$ of a 10 per cent solution of 
carbochrome ink (Gurr Ltd, High Wycombe, Bucks) in BSS. This facilitated differentiation between thymus and adherent lymph nodes in order to avoid contamination of the thymocyte suspension.

\section{Assay for $P F C$}

IgM-, IgG- and IgA-PFC were determined as described previously (Benner et al., 1974a). From the results of the femoral bone marrow the number of $\mathrm{PFC}$ present in the marrow of the whole animal was estimated, using the data of Chervenick, Boggs, Marsh, Cartwright and Wintrobe (1968), who showed that in mice one femur contains 5.9 per cent of the marrow.

\section{Statistics}

Calculation of the 95 per cent confidence limits associated with the number of plaques counted, was done as described in our previous paper (Benner et al., 1974a). The presence of IgG- and IgA-PFC was considered to be significant when there was no overlap between the upper limit in the direct assay and the lower limit in the indirect assay.

\section{Preparation for histological examination}

For light and electron microscopic preparation mice were fixed using a perfusion fixation device. Technical details are described in a previous paper from this laboratory (Van Ewijk, Verzijden, Van der Kwast and Luijcx-Meijer, 1974).

\section{RESULTS}

EFFECTS OF DOSE AND ROUTE OF PRIMING ON SECONDARY PFG RESPONSES IN THE BONE MARROW

Mice were primed with SRBC either i.v., i.p. or s.c. The priming dose was either $10^{5}$, $10^{6}, 10^{7}, 10^{8}$ or $10^{9} \mathrm{SRBC}$. Two months later all mice were splenectomized to prevent a regulatory effect of the spleen on the $\mathrm{PFC}$ activity in the bone marrow during the secondary response. A suppressive influence of the spleen on the $\mathrm{PFC}$ activity in the bone marrow during the secondary response has been described previously (Benner et al., 1974a). One month after splenectomy all mice were boosted with $10^{9}$ SRBC i.v. On the 6 th day after boosting five animals from each group were killed and the number of IgM-, IgG-and $\operatorname{IgA-PFC~was~determined~in~the~femoral~bone~marrow.~This~day~was~chosen~because~the~}$ peak $\mathrm{PFC}$ activity in mouse bone marrow was previously found to occur on approximately the 6th day (Benner et al., 1974a). From the results of the femoral bone marrow the number of PFC present in the marrow of the whole animal was estimated, using the data of Chervenick et al. (1968).

Secondary IgM-, IgG- and IgA-PFC activity in bone marrow could be clearly demonstrated after i.v. as well as after i.p. and s.c. priming at all doses tested. However, only after i.v. priming with $10^{5} \mathrm{SRBC}$ could no significant number of IgA-PFC be demonstrated (Fig. 1). In contrast, bone marrow of unprimed, but otherwise similarly treated mice contained 1240 IgM-PFC, but no significant numbers of IgG- and IgA-PFC. The relationship between priming dose and secondary response was different for the three routes of priming tested. After i.p. and s.c. priming with SRBC the numbers of PFG increased with the number of SRBC used for priming. After i.p. priming a plateau was reached with a dose of $10^{7} \mathrm{SRBC}$. On the other hand after i.v. priming an optimum dose 
of SRBC was reached. The latter curves show that this optimum dose is about $10^{7}-10^{8}$ SRBC for IgM- as well as for IgG- and IgA-PFC responses at an interval of 3 months between priming and boosting.
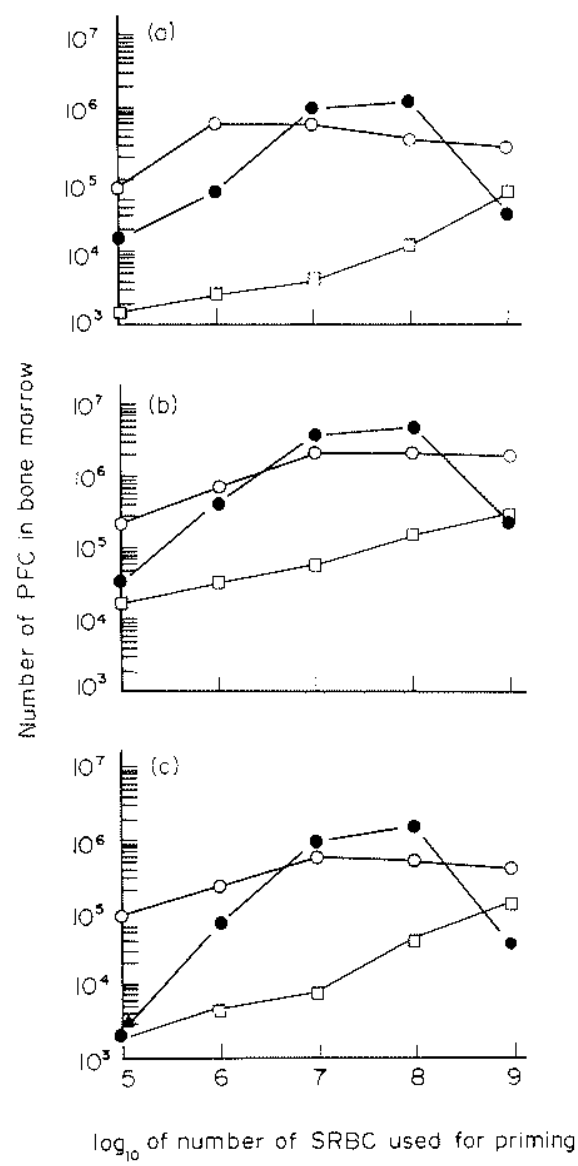

FIG. 1. Number of PFG in mouse bone marrow 6 days after the booster injection of SRBC. Mice were primed with either $10^{5}, 10^{6}, 10^{7}, 10^{8}$ or $10^{9} \mathrm{SRBC}$. A second injection of $10^{9}$ SRBC i.v. was given 3 months later. All mice were splenectomized 1 month before the second injection. (O) i.v., (O) i.p. and (a) s.c. primed mice. Where $(\mathbf{A})$ is added to an experimental point it means that the number of IgAPFC above the level of IgM-PFC was not significant. (a) IgM-PFC. (b) IgG-PFC. (c) IgA-PFC.

Using the experimental approach described in the preceeding section we studied the appearance of the IgG- and the IgA-memory cells in the bone marrow in relation to the priming dose when the interval between priming and boosting was shortened from 3 to 2 months. In this experiment mice were primed with either $10^{5}, 3.3 \times 10^{5}, 10^{6}$ or $3.3 \times 10^{6}$ SRBC i.v. Two months later all mice were splenectomized and boosted within 24 hours with $10^{9}$ SRBC i.v. On the 6 th day after boosting five mice from each group were killed and the number of IgM-, IgG- and IgA-PFG was determined in the femoral bone marrow. In mice primed with $10^{5} \mathrm{SRBC}$ only IgM-PFC were found on the 6th day after boosting (Fig. 2). Significant numbers of IgG- and IgA-PFC could not be demonstrated in the bone marrow of these mice. After priming with $3.3 \times 10^{5} \mathrm{SRBC}$ IgM-PFC as well as 
IgG-PFG were found to be present in the bone marrow. In these mice the number of IgM-PFC+IgA-PFC did not differ significantly from the number of IgM-PFC. Still higher priming doses $\left(10^{6}\right.$ and $\left.3.3 \times 10^{6} \mathrm{SRBC}\right)$ resulted in the appearance of secondary IgA-PFC as well. Since the development of PFC in mouse bone marrow is dependent on the presence of specific B and T memory cells (Benner et al., 1974b), these results indicate that the appearance of $I g G$ - and IgA-memory cells specific for SRBC in mouse bone marrow is dose-dependent.

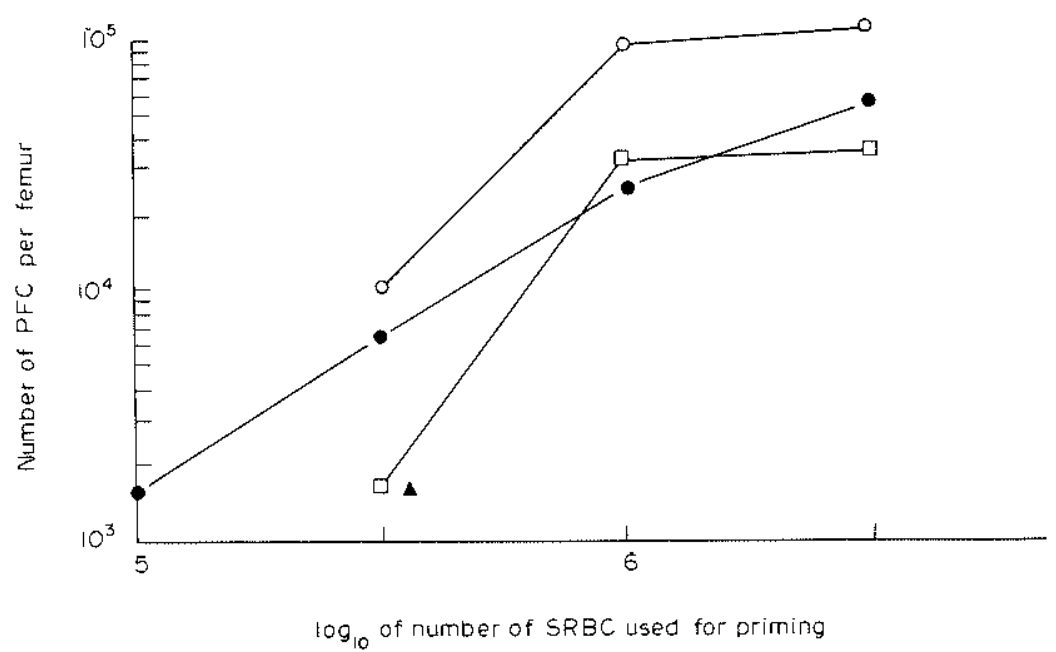

Fig. 2. Number of PFC per mouse femur 6 days after the booster injection of SRBC. Mice were primed with either $10^{5}, 3.3 \times 10^{5}, 10^{5}$ or $3.3 \times 10^{6} \mathrm{SRBC}$ i.v. A second i.v. injection of $10^{9} \mathrm{SRBC}$ was given 2 months later. All mice were splenectomized 1 day before the second injection. (-) IgM-PFC, (O)

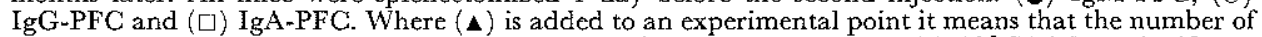
IgA-PFC above the level of IgM-PFC was not significant. After priming with $10^{5} \mathrm{SRBC}$ no significant numbers of IgG- and IgA-PFC were found. After priming with $3 \cdot 3 \times 10^{5}$ no significant numbers of IgA-PFC could be demonstrated. In the femoral bone marrow of unprimed, but otherwise similarly treated mice only forty-six IgM-PFC were found.

\section{EFFECTS OF BOOSTER DOSE ON SECONDARY PFC RESPONSES}

Mice were primed with $10^{7} \mathrm{SRBC}$ i.v. This dose is optimal for the appearance of memory cells in the bone marrow at an interval of 2 months between priming and boosting (Benner, Meima and Van der Meulen, unpublished observations). Two months after priming the animals were boosted with either $10^{4} \mathrm{SRBC}, 10^{6} \mathrm{SRBC}$ or $10^{9} \mathrm{SRBC}$ i.v. Four or five mice from each group were killed at various times after boosting and the number of IgM-, IgG- and IgA-PFC was determined in spleen, femoral bone marrow, thymus, mesenteric lymph node, peripheral lymph nodes (inguinal, axillary and brachial) and Peyer's patches (only the patches of the small intestine were used). From the results obtained with the femoral bone marrow the number of PFC in the bone marrow of the whole animal was calculated.

Each booster dose tested induced the appearance of IgM-, IgG- and IgA-PFC in spleen and bone marrow (Figs 3-5). Significant numbers of PFC in thymus, mesenteric lymph node, peripheral lymph nodes, and Peyer's patches were observed only after boosting with $10^{9} \mathrm{SRBC}$ (Fig. 6). After boosting with $10^{4} \mathrm{SRBC}$ as well as with $10^{6}$ and 
$10^{9} \mathrm{SRBC}$ the numbers of PFC in the spleen rose rapidly. The peak $\mathrm{PFC}$ activity in the bone marrow was reached after the appearance of the peak numbers of PFC in the spleen for each booster dose. Between the 7th and 10th day after boosting the numbers of PFC of each antibody class in the bone marrow rose to levels which surpassed the levels in the spleen. After the 10th day the numbers of PFG in the bone marrow were always much higher than in the other lymphoid organs.
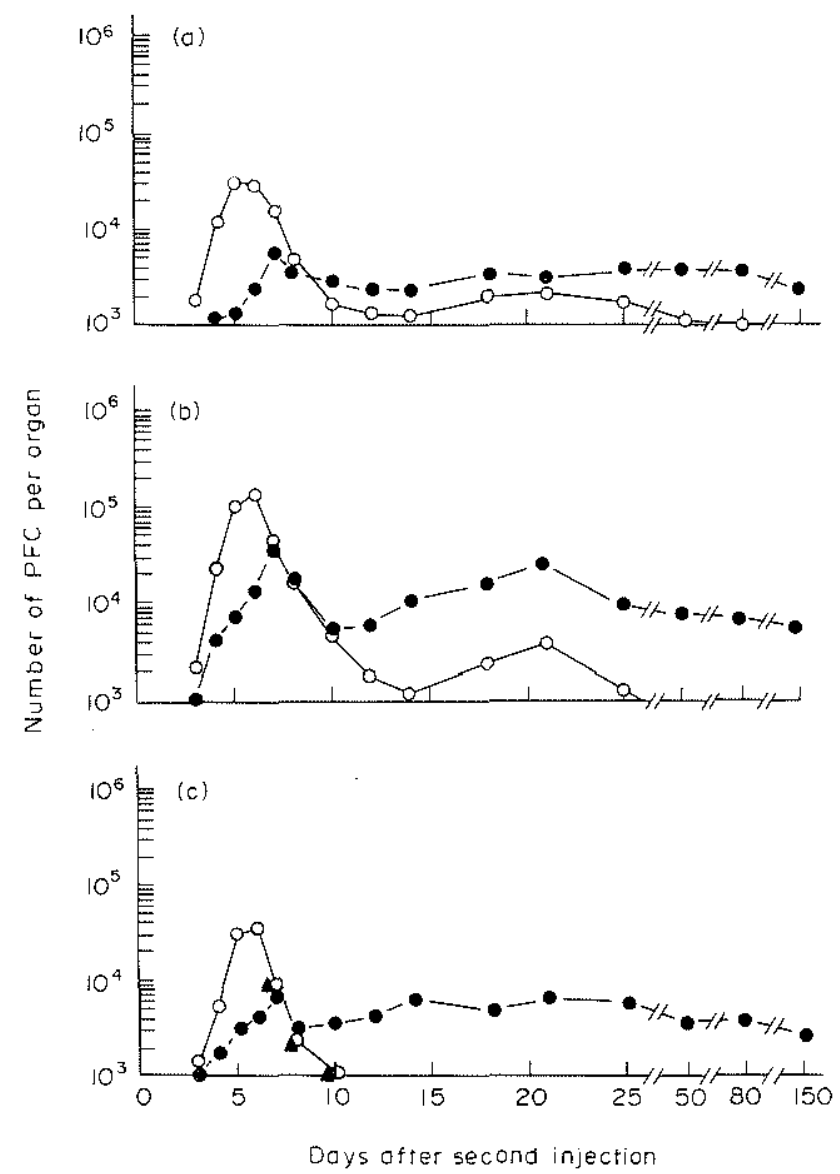

Firg. 3. Number of PFC in mouse spleen and bone marrow after two injections of SRBC. Mice were primed with $10^{7}$ SRBC i.v. and boosted with $10^{4}$ SRBC i.v. 2 months later. (0) Spleen and (1) bone marrow. Where (A) is added to an experimental point it means that the number of IgA-PFC above the level of IgM-PFC was not significant. (a) IgM-PFC. (b) IgG-PFC. (c) IgA-PFC.

The prolonged presence of $\mathrm{PFC}$ in the thymus after boosting with $10^{9} \mathrm{SRBC}$ i.v. (Fig. 6 ) is remarkable. This thymic $\mathrm{PFG}$ activity was not found after boosting with $10^{4} \mathrm{SRBC}$ i.v. or $10^{6} \mathrm{SRBC}$ i.v., therefore the appearance of PFC in the thymus is dependent on the booster dose. Histological examination of the thymus of mice primed with $10^{7} \mathrm{SRBC}$ i.v. and boosted with $10^{9} \mathrm{SRBC}$ i.v., showed the presence of plasma cells in the medulla. These plasma cells were localized predominantly around blood vessels (Figs 7-10). Close investigation of the thymus of normal mice did not reveal the presence of plasma cells. 
In the thymic medulla of the immune mice cells were less densely packed compared with control thymus. In addition many macrophages and granulocytes were observed in the thymic medulla of these mice. Unlike granulocytes, macrophages were found to be closely associated with blood vessels (Fig. 9).
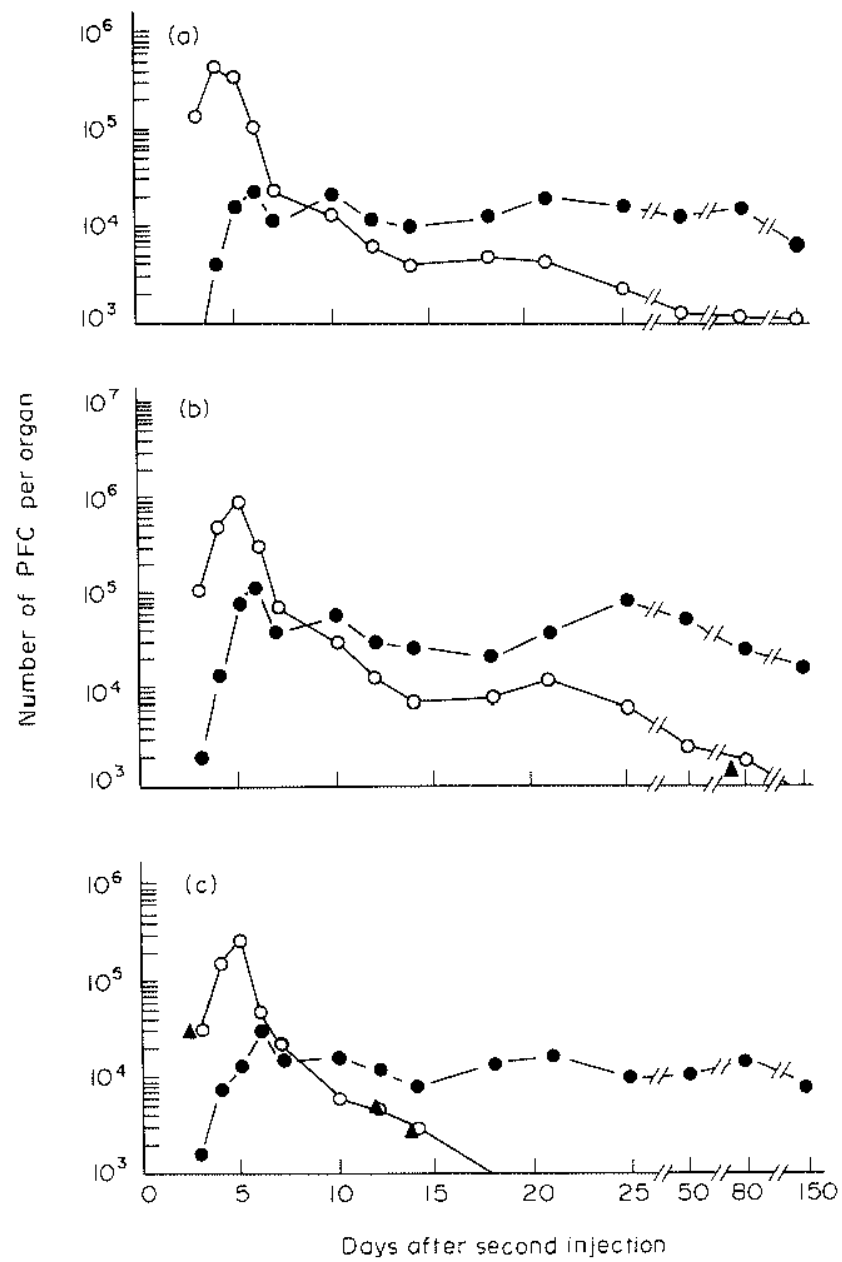

FxG. 4. Number of PFG in mouse spleen and bone marrow after two injections of SRBC. Mice were primed with $10^{7}$ SRBC i.v. and boosted with $10^{6}$ SRBC i.v. 2 months later. (O) Spleen and (O) bone marrow. Where $(\boldsymbol{A})$ is added to an experimental point it means that the number of IgG- or IgA.PFC above the level of IgM-PFC was not significant. (a) IgM-PFC. (b) IgG-PFC. (c) IgA-PFC.

Analysis of the ratio of IgA-PFC:IgM-PFC in spleen, bone marrow and thymus during the secondary response reveals that this ratio is different in these three organs. From Figs 3-6 it can be calculated that in general this ratio is about 1 or less in spleen, about 1.5 in bone marrow and about 2 in thymus.

\section{DISCUSSION}

The presence of specific $\mathrm{B}$ and $\mathrm{T}$ memory cells in mouse bone marrow is required before 
In the thymic medulla of the immune mice cells were less densely packed compared with control thymus. In addition many macrophages and granulocytes were observed in the thymic medulla of these mice. Unlike granulocytes, macrophages were found to be closely associated with blood vessels (Fig. 9).
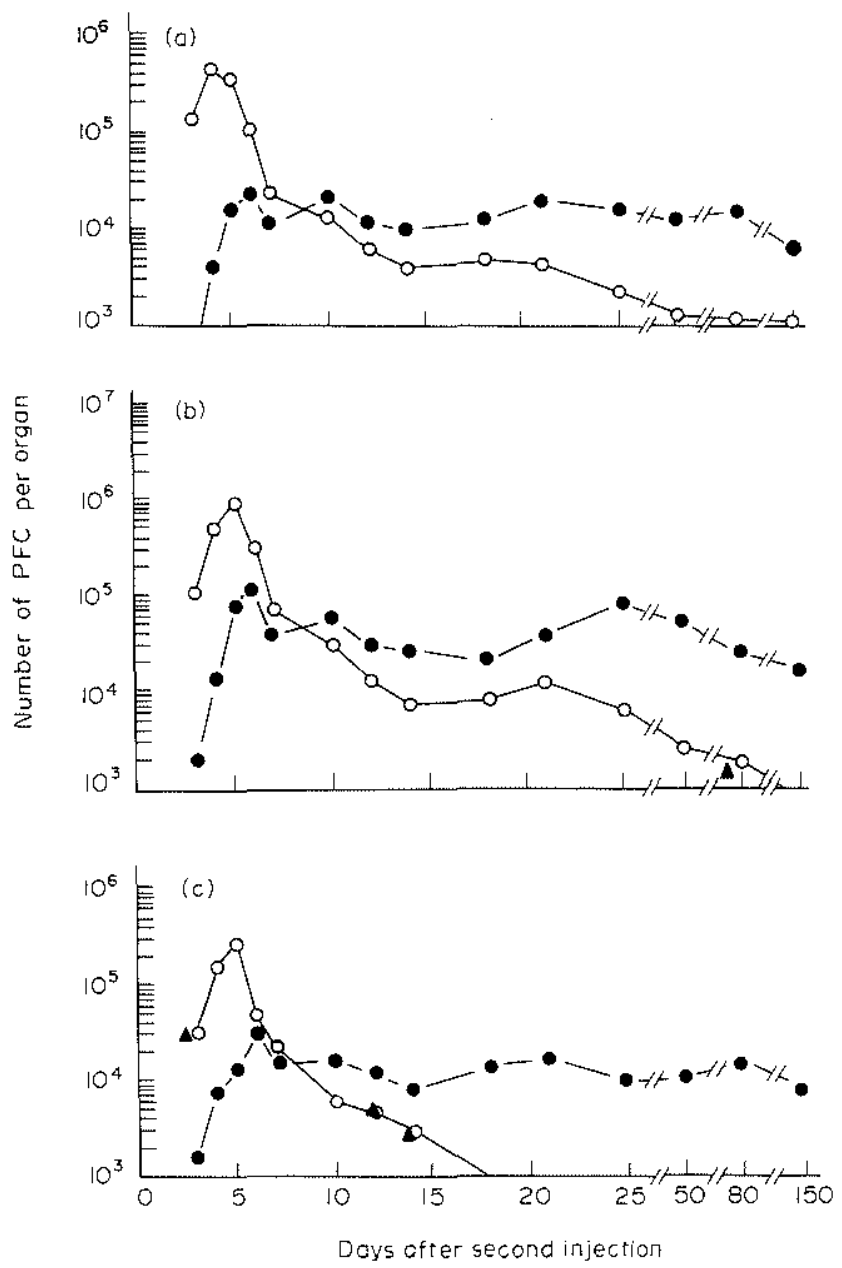

FIG. 4. Number of PFG in mouse spleen and bone marrow after two injections of SRBC. Mice were primed with $10^{7}$ SRBC i.v. and boosted with $10^{6}$ SRBC i.v. 2 months later. (0) Spleen and ( $)$ bone marrow. Where ( $\mathbf{\Lambda})$ is added to an experimental point it means that the number of IgG- or IgA-PFC above the level of IgM-PFC was not significant. (a) IgM-PFC. (b) IgG-PFC. (c) IgA-PFC.

Analysis of the ratio of IgA-PFC:IgM-PFC in spleen, bone marrow and thymus during the secondary response reveals that this ratio is different in these three organs. From Figs 3-6 it can be calculated that in general this ratio is about 1 or less in spleen, about 1.5 in bone marrow and about 2 in thymus.

\section{DISCUSSION}

The presence of specific $\mathrm{B}$ and $\mathrm{T}$ memory cells in mouse bone marrow is required before 
The question arises whether the B memory cells in the bone marrow, which are stimulated in situ to antibody synthesis (Benner et al., 1974a), also originate in situ in this organ or derive from other lymphoid organs. The generation of B memory cells is thought to take place in germinal centre reactions (Thorbecke, 1969; Durkin and Thorbecke, 1971; Nieuwenhuis, 1971). Although germinal centres are reported to be occasionally present in bone marrow (Duhamel, 1968), we could not find these reaction centres after primary immunization with SRBC (Van Ewijk and Benner, unpublished observations). Since B
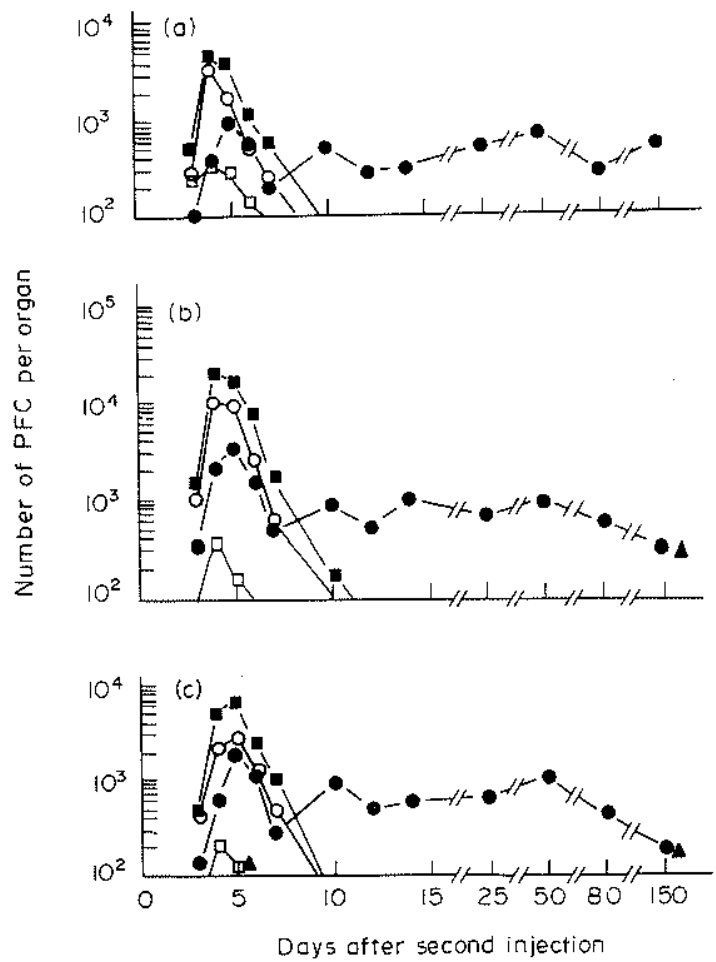

Fig. 6. Number of PFC in mouse mesenteric lymph node, peripheral lymph nodes, thymus and Peyer's patches. Mice were primed with $10^{7} \mathrm{SRBC}$ i.v. and boosted with $10^{9} \mathrm{SRBC}$ i.v. 2 months later. The organs were obtained from the very same mice used to determine the numbers of PFC in spleen and

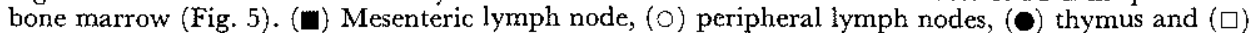
Peyer's patches. Where $(\boldsymbol{\Lambda})$ is added to an experimental point it means that the number of IgG- or IgA-PFC above the level of IgM-PFC was not significant. (a) IgM-PFC. (b) IgG-PFC. (c) IgA-PFC.

memory cells recirculate (Miller and Sprent, 1971) it is quite possible that B memory cells which are generated in spleen and lymph nodes circulate through and home in bone marrow. The different effects of the priming dose after either i.v., i.p. or s.c. priming (Fig. 1) might then be due to a difference between spleen and lymph nodes in dose-dependence of the development of B memory cells. However, it is also possible that only spleenderived $\mathrm{B}$ memory cells are able to home in bone marrow. In that case the s.c. priming effect in terms of secondary PFC responses in bone marrow is due to s.c. antigens entering the circulation and stimulating the spleen. Then the priming dose-secondary response curves after s.c. priming represent the left part of the curves after i.v. and i.p. priming. 


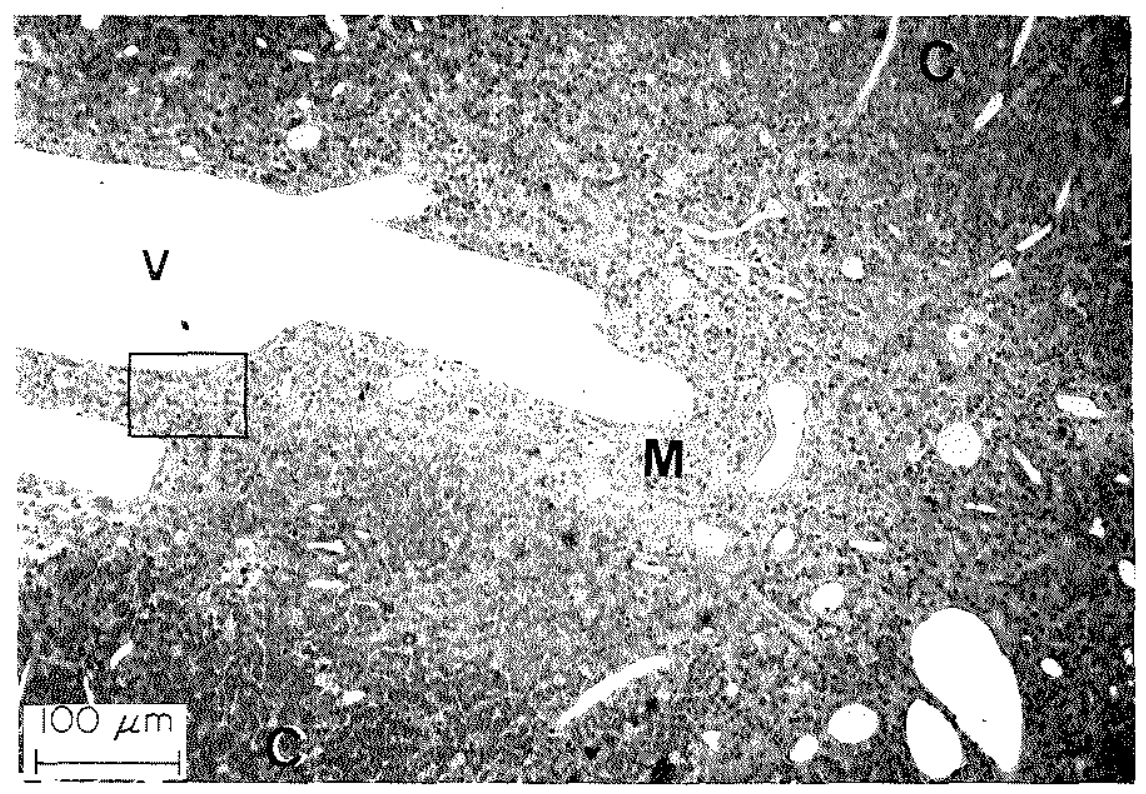

Frg. 7. Low magnification of mouse thymus 6 days after the second injection of SRBC. Mice were primed with $10^{7}$ SRBC i.v. and boosted with $10^{9}$ SRBC i.v. 2 months later. A $1-\mu \mathrm{m}$ Epon section, stained with 1 per cent Toluidine Blue in $0 \cdot 1 \mathrm{M}$ borax buffer. Blood vessels (V) are cleared from blood, due to the perfusion fixation. $\mathrm{C}=$ cortex. $\mathrm{M}=$ medulla.

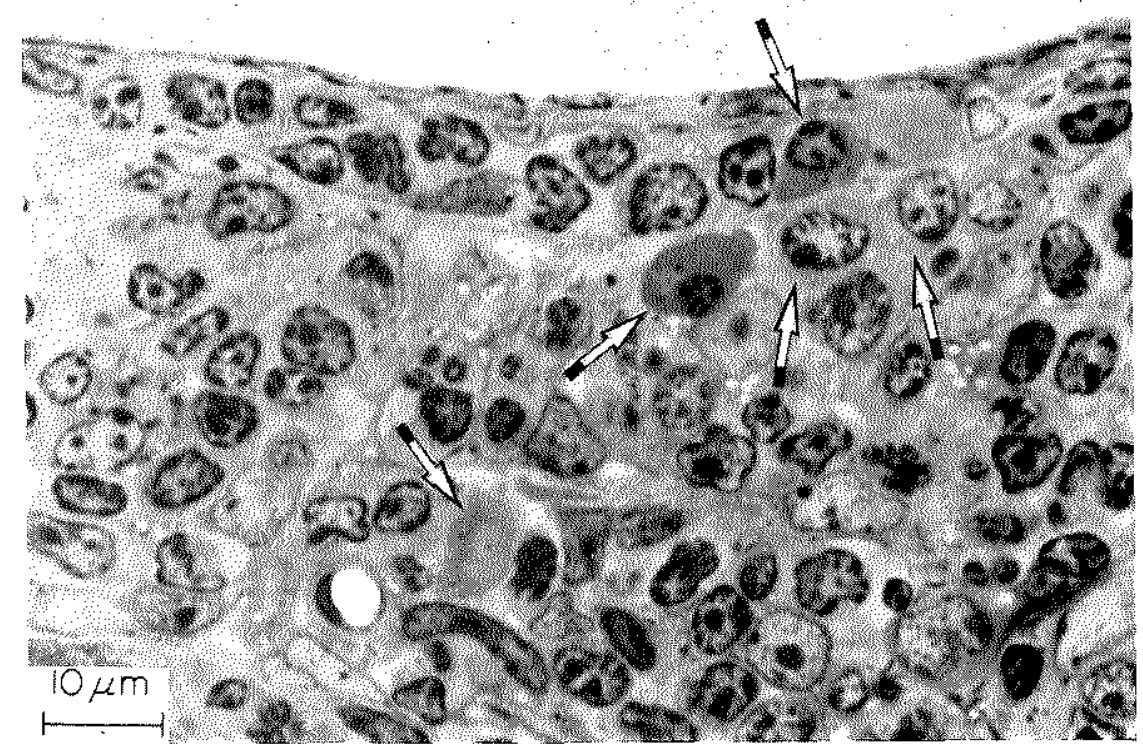

FIG. 8. Thymic medulla. Higher magnification of selected area of Fig. 7. Plasma cells (arrows) are localized around blood vessels. 


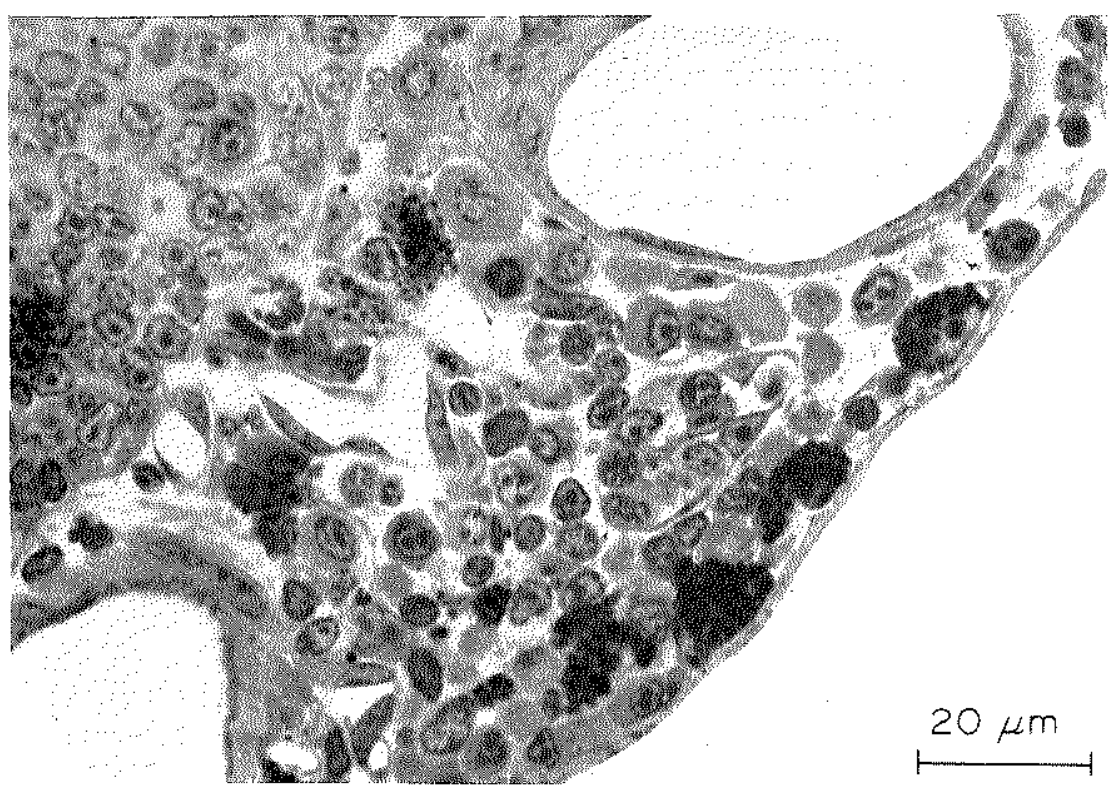

FrG. 9. Thymic medulla of an immune mouse. Plasma cells and macrophages are closely associated with blood vessels.

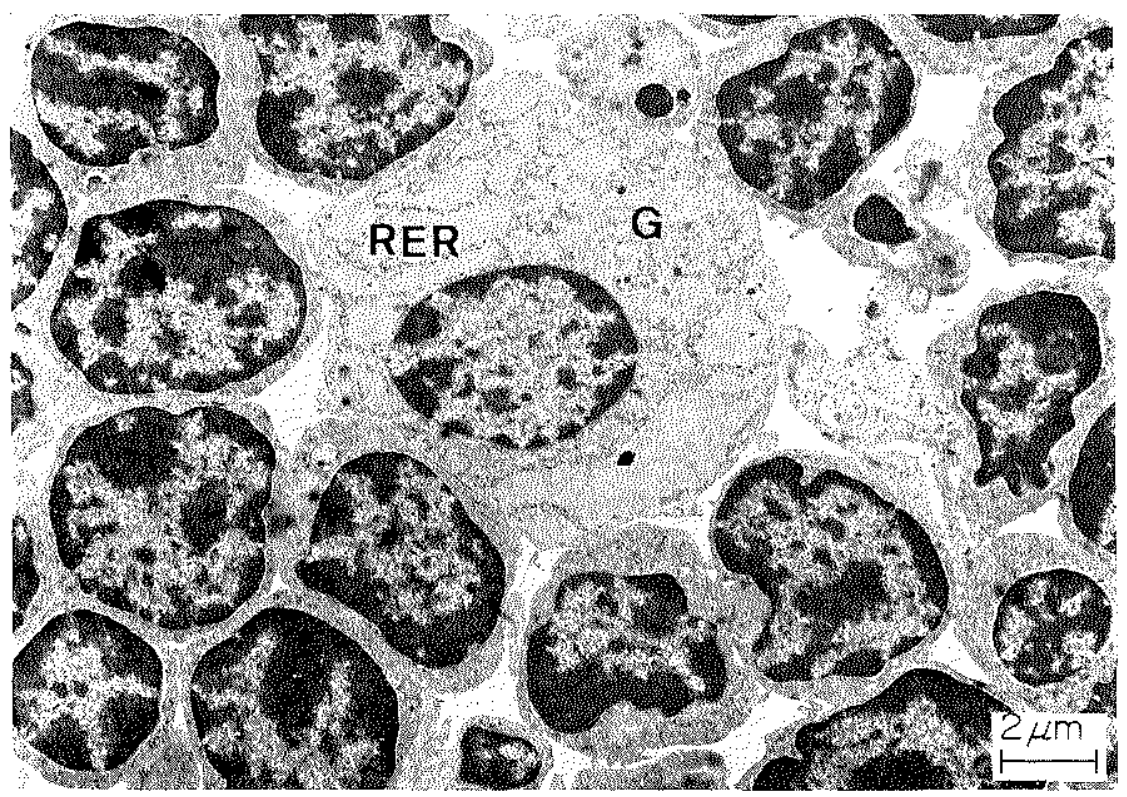

Fig. 10. Electron micrograph of a plasma cell with dilated rough endoplasmic reticulum (RER) observed in the thymic medulla of an immune mouse. $G=$ Golgi region. 
The sequence of appearance of B memory cells of different antibody classes in the bone marrow after increasing doses of SRBC was found to be $\operatorname{IgM}, \operatorname{IgG}, \operatorname{IgA}$ (Fig. 2). The same sequence has been described with regard to the dose-dependence of splenic PFC in the primary response (Wortis, Dresser and Anderson, 1969) and the appearance in time of splenic PFG during the primary response (Wortis et al., 1969; Benner et al., 1974a). The preferential IgM-PFC response during the first days of a primary response may be due to a preponderance of IgM-B cells at the sites of first encounter between antigen, B cells and $\mathrm{T}$ cells. In the secondary response to SRBC IgM-, IgG- and IgA-PFC appeared nearly simultaneously and independently of the booster dose (Figs 3-5), probably due to the high numbers of specific $B$ and $T$ cells in spleen and bone marrow of immune mice (Cunningham and Sercarz, 1971; Niederhuber and Möller, 1973; Benner et al., 1974b).

Another difference between primary and secondary PFC response is the interval between immunization and time of peak PFC activity. In the primary response to SRBC the peak $\mathrm{PFC}$ activity in the spleen is delayed with suboptimal doses of antigen (Sercarz and Byers, 1967). This phenomenon was less prominent in spleen and bone marrow during the secondary response to SRBC (Figs 3-5). The amount of specific $\mathrm{T}$ cells in the spleen of non-immune mice is probably limiting for a maximal PFC response to SRBC (Campbell, 1972; Zaalberg, Van der Meul and Rossi, 1973). At higher doses of SRBC the number of specifically stimulated $\mathrm{B}$ and $\mathrm{T}$ cells will increase. Thus the chance of interaction between antigen, $B$ cells and $T$ cells will be enhanced. Consequently the peak $\mathrm{PFC}$ activity in the primary response to $\mathrm{SRBC}$ is reached earlier with high antigen doses. After antigenic stimulation the number of specific $\mathrm{B}$ and $\mathrm{T}$ cells in spleen and bone marrow also increase. The abundance of specific $\mathrm{B}$ and $\mathrm{T}$ cells in spleen and bone marrow of immune mice (Benner et al., 1974b) is the probable cause of the weaker antigen dose-dependence of the time interval between secondary immunization and peak PFC activity in the secondary response.

The thymus is generally considered to be a primary lymphoid organ, since it produces lymphocytes which are of major importance for the immunological capacity of other lymphoid organs (Miller and Davies, 1964). Small numbers of PFC were reported to be present in the thymus during the late phase of the primary response after i.p. immunization with SRBC (Chaperon, Selner and Claman, 1968; Anderson and Dresser, 1972). It is difficult to prove that PFG activity in a thymus cell suspension is due to the presence of PFC in the thymus itself, since this organ is closely associated with the adherent lymph nodes. We tried to avoid contamination of the thymocyte suspension with lymph node cells by using the carbon-injection technique of Leckband and Boyse (1971). After priming with $10^{7}$ SRBC i.v. and boosting with $10^{9}$ SRBC i.v., but not with the lower doses, a clear PFC activity in the thymus resulted (Fig. 6). Thymic PFC activity could be due to migration of PFG from the spleen into the thymus (Chaperon et al., 1968). However, the possibility of differentiation of $\mathrm{B}$ cells into PFC within the thymus has to be considered. The development of anti-SRBC PFC within the thymus requires the presence of appropriate B cells in situ and entrance of antigen into the thymus. In a previous paper it was reported that after i.v. priming with SRBC B memory cells appear in the thymus (Benner et al., 1974b). Okumura and Tada (1973) showed that thymocytes can be primed in situ by i.p. injected heterologous red blood cells. We suggest that in the late phase of the primary response and after boosting with the same antigen $B$ memory cells can differentiate with the help of specific $\mathrm{T}$ cells into PFC within the thymus. Histological examination of the thymus of mice primed with $10^{7} \mathrm{SRBC}$ i.v. and boosted with $10^{9} \mathrm{SRBC}$ i.v. provides evidence for 
such a differentiation in situ. The presence of macrophages studded with phagocytosed material and the presence of relatively large numbers of plasma cells in the neighbourhood of these macrophages (Fig. 9) suggest that the thymus can act as a secondary lymphoid organ.

The large proportion of IgA-PFC in the thymus (Fig. 6) is remarkable. By immunofluorescent analysis Allen and Porter (1973) showed a high percentage of the few plasma cells present in piglet thymus to contain IgA. Possibly the endodermal origin of the thymus is the underlying cause.

\section{ACKNOWLEDGMENTS}

We are very indebted to Professor Dr O. Vos, Dr O. B. Zaalberg (The Medical Biological Laboratory, Rijswijk, The Netherlands) and Dr G. H. Blijham (University of Groningen, The Netherlands) for helpful suggestions, criticisms and assistance in the preparation of the manuscript.

We also wish to express our thanks to $\mathrm{Mr}$ N. H. C. Brons for excellent technical assistance, Dr O. B. Zaalberg for supplying the rabbit anti-mouse IgG serum and to Dr J. Veldkamp (National Institute of Public Health, Bilthoven, The Netherlands) for the generous gift of the rabbit anti-mouse IgA serum.

This investigation was supported by the Netherlands Foundation for Medical Research (FUNGO).

\section{REFERENCES}

Allen, W. D. and Porter, P. (1973). "The relative distribution of $\operatorname{IgM}$ and $\operatorname{IgA}$ cells in intestinal mucosa and lymphoid tissues of the young unweaned pig and their significance in ontogenesis of secretory immunity.' Immunology, 24, 493.

Anderson, H. R. and Dresser, D. W. (1972). 'The long-term distribution of antibody-forming cells.' Europ. 7. Immunol., 2, 410 .

Benner, R., Meima, F., Van der Meulen, G. M. and Van Muiswinkex, W. B. (1974a). 'Antibody formation in mouse bone marrow. I. Evidence for the development of plaque-forming cells in situ.' Immuno$\log , 26,247$.

Benner, R., Meima, F. and Van der Meulen, G. M. (1974b). "Antibody formation in mouse bone marrow. II. Evidence for a memory-dependent phenomenon.' Cell. Immunol. (In press.)

CAMprell, P. A. (1972). 'T cells: the limiting cells in the initiation of immune responses in normal mouse spleens.' Cell. Immunol., 5, 338.

Chaperon, E. A., Selner, J. C. and Claman, H. N. (1968). "Migration of antibody-forming cells and antigen-sensitive precursors between spleen, thymus and bone marrow.' Immunology, 14, 553.

Chervenick, P. A., Boggs, D. R., Marsh, J. C., Cartwright, G. E. and Wintrobe, M. M. (1968). 'Quantitative studies of blood and bone marrow neutrophils in normal mice.' Amer. F. Physiol., 215, 353.

Cunningham, A. J. and Sergarz, E. E. (1971). 'The asynchronous development of immunological memory in helper (T) and precursor (B) cell lines.' Europ. 7. Immunol., 1, 413.

Duhamel, G. (1968). "Les nodules lymphoïdes de la moelle osseuse. Aspect physiologique et pathologique.
Essai d'interprétation.' La Presse Medicale, 76, 1947.

Durkin, H. G. and Thorbecke, G. J. (1971). 'Relationship of germinal centers in lymphoid tissue to immunologic memory. $V$. The effect of prednisolone administered after the peak of the primary response.' F. Immunol., 106, 1079 .

Hanna, M. G. and Peters, L. C. (1971). 'Requirement for continuous antigenic stimulation in the development and differentiation of antibody-forming cells: effect of antigen dose.' Immunology, 20, 707.

LECKBAND, E. and Boyse, E. A. (1971). 'Immunocompetent cells among mouse thymocytes: a minor population.' Science, 172, 1258.

Miller, J. F. A. P. and Davies, A. J. S. (1964). 'Embryological development of the immune mechanism.' Ann. Rev. Med., 15, 23.

Miller, J. F. A. P. and Sprent, J. (1971). 'Cell-tocell interaction in the immune response. VI. Contribution of thymus-derived cells and antibodyforming cell precursors to immunological memory.' 7. $\exp$. Med., 134, 66 .

Mrshell, R. I. and Dutton, R. W. (1967). 'Immunization of dissociated spleen cell cultures from normal mice.' 7. exp. Med., 126, 423.

Niederhuber, J. E. and Möller, E. (1973). 'Antigenic markers on mouse lymphoid cells: origin of cells mediating immunologic memory.' Cell. Immunol., $6,407$.

NieuwenHuis, P. (1971). On the origin and fate of immunologically competent cells. Thesis, Groningen, The Netherlands.

OKumurA, K. and TADA, T. (1973). 'Suppression of hapten-specific antibody response by carrierspecific T-cells.' Nature: New Biology, 245, 180.

Sercarz, E. E. and Byers, V. S. (1967). 'The X-Y-Z 
scheme of immunocyte maturation. III. Early IgM memory and the nature of the memory cell.' $\mathcal{J}$. Immunol., 98, 836 .

Thorbecke, G. J. (1969). 'Germinal centers and immunological memory.' Lymphatic Tissue and Germinal Centers in Immune Response (ed. by $\mathrm{L}$. Fiore-Donati and M. G. Hanna), p. 83. Plenum Press, New York.

VAN EWIJK, W., VERzIjDEN, J. H. M., VAN der Kwast, T. H. and Lurjcx-Merjer, S. W. M. (1974). 'Reconstitution of the thymus dependent area in the spleen of lethally irradiated mice. A light and electronmicroscopical study of the $T$ cell microenvironment.' Cell. Tissue Res., 149, 43.

Wortis, H. H., Dresser, D. W. and Anderson, H. R. (1969). 'Antibody production studied by means of the localized haemolysis in gel (LHG) assay. III. Mouse cells producing five different classes of antibody.' Immunology, 17, 93.

ZaAlberg, O. B., Van der Mevl, V. A. and Rossi, G. (1973). "The effect of X-irradiation on the appearance of antibody-forming cells in mouse spleen following the injection of sheep erythrocytes.' Europ. F. Immunol., 3, 698 . 




\title{
Antibody Formation in Mouse Bone Marrow
}

\section{The Influence of Splenectomy on the Bone Marrow Plaque-Forming Cell Response to Sheep Red Blood Cells}

\author{
Robbert Benner and Adrianus van OUdenaren
}

Department of Cell Biology and Genetics, Erasmus University, Rotterdam, The Netherlands

\author{
Received March 17, 1975
}

\begin{abstract}
Mouse bone marrow is barely capable of plaque-forming cell (PFC) activity during the primary response to sheep red blood cells (SRBC). However, during the secondary response, it becomes the major center of activity containing IgM-, IgG-, and $\operatorname{IgA}-\mathrm{PFC}$. In the present paper the influence of splenectomy was studied on primary and secondary PFC activity in the bone marrow. Differences in primary and secondary bone marrow $\mathrm{PFC}$ responses are probably related to the presence of $\mathrm{B}$ and $T$ memory cells in situ. Therefore the effect of splenectomy on the appearance of $\mathrm{B}$ and $\mathrm{T}$ memory cells in the bone marrow was also investigated. Splenectomy before intravenous (iv) immunization with $4 \times 10^{8} \mathrm{SRBC}$ prevented any primary $\mathrm{PFC}$ activ: ity in the bone marrow. The influence of splenectomy before priming on secondary $\mathrm{PFC}$ activity in the bone marrow depended on the priming dose of SRBC. Splenectomy before priming with $10^{7} \mathrm{SRBC}$ iv completely prevented $\operatorname{IgM}-, \operatorname{IgG}-$, and $\operatorname{IgA}$ PFC activity in the bone marrow upon subsequent boosting with $4 \times 10^{8} \mathrm{SRBC}$ iv. By means of cell transfer experiments it was shown that after splenectomy no $B$ or $T$ memory cells appeared in the bone marrow after priming with $10^{7} \mathrm{SRBC}$ iv. The effect of splenectomy on both secondary $\mathrm{PFC}$ activity and appearance of $\mathrm{B}$ and $\mathrm{T}$ memory cells in the bone marrow could be partly overcome by iv priming with a higher antigen dose of $4 \times 10^{8} \mathrm{SRBC}$. Cell transfer experiments showed that splenectomy before priming with $10^{7} \mathrm{SRBC}$ iv not only interfered with the appearance of $\mathrm{B}$ and $T$ memory cells in the bone marrow, but also with the appearance of $B$.memory cells in peripheral lymph nodes, mesenteric lymph node, Peyer's patches, thymus, and blood. This indicates that after immunization with $10^{7}$. SRBC iv all $\mathrm{B}$ and $\mathrm{T}$ memory cells which appear at extra splenic sites, are generated in the spleen. Immunization of splenectomized mice with $4 \times 10^{8} \mathrm{SRBC}$ iv did induce the appearance of $\mathrm{B}$ memory cells in peripheral lymph nodes, mesenteric lymph node, Peyer's patches, thymus, and blood. We suggest that small amounts of a high dose of iv inoculated SRBC can induce the generation of $\mathrm{B}$ memory cells in lymph nodes and Peyer's patches.
\end{abstract}

\section{INTRODUCTION}

During the primary response to sheep red blood cells (SRBC), plaque-forming cells (PFC) can be barely demonstrated in mouse bone marrow. However, a very distinct IgM-, IgG-, and IgA-PFC activity is present in this organ during the secondary response $(1,2)$. Independent of the booster dose this activity in the bone marrow rises to a level which surpasses the total level in all the other lymphoid organs (2). Evidence was presented that the antibody-forming cells which appear in the bone marrow can be generated in situ. To initiate such a bone 
marrow $\mathrm{PFC}$ response to $\mathrm{SRBC}$, the presence of specific $\mathrm{B}$ and $\mathrm{T}$ memory cells seems to be required (3).

The site of origin of the $\mathrm{B}$ and $\mathrm{T}$ memory cells which appear in the bone marrow after intravenous (iv) priming with SRBC (3) is not clear. B memory cells are thought to be generated in germinal centre reactions (4-6). These germinal centre reactions are only incidentally found in bone marrow $(7,8)$, but abundantly present in spleen and lymph nodes (6).

About the origin of T memory cells Miller and Mitchell (9) hypothesized in 1969 that "lymphocytes which emigrate from the thymus are short-lived cells and can establish a progeny of long-lived recirculating cells only if they interact with antigens in the appropriate environment of the secondary lymphoid tissues".

In the present paper data will be presented about the influence of splenectomy on the bone marrow PFC response to SRBC. In addition cell transfer experiments are described which deal with the origin of the $B$ and $T$ memory cells which appear in the bone marrow after iv priming with SRBC. The results suggest that the spleen is the most important breeding site of these memory cells after iv antigen administration.

\section{MATERIALS AND METHODS}

Mice. $(\mathrm{C} 57 \mathrm{BL} / \mathrm{Rij} \times \mathrm{CBA} / \mathrm{Rij}) \mathrm{F}_{1}$ female mice, $16-20$ wk old were used. They were purchased from the Medical Biological Laboratory, Rijswijk, The Netherlands, and the Laboratory Animals Centre of the Erasmus University, Rotterdam, The Netherlands.

Antigen. Sheep red blood cells were obtained from the Department of Clinical Microbiology of the Erasmus University, Rotterdam, The Netherlands. Before use the cells were washed three times in phosphate buffered saline $(\mathrm{pH} 7.2)$.

Immunization. Mice were primed with an iv injection of either $10^{7}$ or $4 \times 10^{8}$ $\mathrm{SRBC}$ in a volume of $0.5 \mathrm{ml}$. For secondary immunization mice received an iv injection of $4 \times 10^{8}$ SRBC. The interval between first and second antigen injection was 4 mo.

Splenectomy. Splenectomy and sham-splenectomy were performed at least $1 \mathrm{mo}$. before injection of SRBC. Mice were anaesthetized by an intraperitoneal (ip) injection of $70 \mathrm{mg} / \mathrm{kg}$ body wt Nembutal (Abbott S.A., Saint-Rémy-sur-Avre, France). The incision was made in the left upper abdomen. For splenectomy the splenic blood vessels were tied in a single suture, then cut and the spleen removed. The incision was closed in two layers. There was no postoperative mortality.

Preparation of cell suspensions. Cell suspensions were prepared in a balanced salt solution (BSS) (10) as described previously (1). Blood was obtained by cardiac puncture and immediately heparinized $(5 \mathrm{U} / \mathrm{ml})$. Thymocytes were collected 30 min after an ip injection of the donors with $0.1 \mathrm{ml}$ of a $1 \%$ solution of carbochrome ink (Gurr Ltd., High Wycombe, Buckinghamshire, England) in BSS. This facilitated differentiation between thymus and adherent lymph nodes in order to avoid contamination of the thymocyte suspension. Corticosteroid resistant thymocytes (CRT) were obtained from 6-wk-old mice injected ip with $30 \mathrm{mg}$ of the synthetic corticosteroid Dexamethasone sodium phosphate (Merck \& Co., Rahway, New Jersey) per kilogram body weight 2 days previously.

Isolation of nucleated cells from peripheral blood. Nucleated cells were isolated from mouse blood using a modification of the Ficoll-Isopaque system described by 
Böyum (11). The Ficoll-Isopaque mixture was obtained by mixing 2 parts Isopaque (Nyegaard \& Co., Oslo, Norway), 3 parts Ficoll (Pharmacia, Uppsala, Sweden) $9 \%$ and 2 parts of a $3.5 \%$ solution of bovine serum albumin in distilled water. Final density was $1.115 \mathrm{~g} / \mathrm{ml}$. Using this method a minimum of $70 \%$ of the nucleated cells were recovered.

Cell counts. Viable cells were counted in a haemocytometer using $0.2 \%$ trypan blue in BSS as a diluent.

Irradiation. The recipient mice received 850 rad whole body irradiation generated in a Philips Müller MG 300 X-ray machine. Animals were irradiated in well-aerated circular Perspex cages. Physical constants of the irradiation were described previously (3). Radiation control mice died in 9-16 days.

Cell transfer. Recipients were injected iv with the appropriate cell suspension and $5 \times 10^{8} \mathrm{SRBC}$ within $4 \mathrm{hr}$ after irradiation. On the fourth day all mice were boosted with $5 \times 10^{8} \mathrm{SRBC}$ ip. $\mathrm{PFC}$ in the spleen of recipient mice were determined 7 days after cell transfer. Seven days after cell transfer PFC activity in the recipient spleen is maximal. Each group consisted of five mice.

Assay for PFC. IgM-, IgG-, and IgA-PFC were determined as described previousiy (1). The monolayer plaque assay sides were made using a double-sided adhesive plastic film (Neschen International, Bückeburg, Western Germany) as described by Majoor, Van't Veer, and Zaalberg (12). Calculation of the 95\% confidence limits associated with the number of plaques counted was done as described previously (1). The presence of IgG- and IgA-PFC was accepted as significant when there was no overlap between the upper limit in the direct assay and the lower limit in the indirect assay.

Calculation of total bone marrow $P F C$ activity. Bone marrow PFC activity was determined in the femoral marrow. From the results of the femoral bone marrow the number of PFC present in the marrow of the whole animal was estimated using the data of Chervenick and co-workers (13), who showed that in mice one femur contains $5.9 \%$ of the total marrow. Comparison of the PFC responses evoked by fixed numbers of nucleated bone marrow ceils from femur, tibia, humerus, and rib (Table 1) indicated that IgM-, IgG-, and IgA-PFC activity in various compartments of mouse bone marrow is about the same.

Serum titration. Agglutinating antibody titres were assayed in duplicate with the standard twofold dilution method using a $1 \%$ solution of SRBC: The samples were tested for the presence of 2-mercaptoethanol (2-ME) sensitive and 2-ME resistant antibodies. For determination of $2-\mathrm{ME}$ resistant antibody titres, the sera were diluted 1:4 with BSS before dilution v/v with $0.2 \mathrm{~mol} 2-\mathrm{ME}$. After incubation for $2 \mathrm{hr}$ at room temperature, the sera were titrated according to the standard method.

\section{RESULTS}

Effects of Splenectomy on Primary and Secondary PFC Activity in the Bone Marrow

Since the spleen is the major organ producing PFC during the primary response to iv inoculated $\mathrm{SRBC}$, it was of interest to investigate whether the bone marrow can take over this function of the spleen some time after splenectomy. To study this, mice were splenectomized 7 mo before first immunization with SRBC. Although $7 \mathrm{mo}$ is about a quarter of their lifetime, the bone marrow of these mice 
TABLE 1

Comparison of PFC Activity in Various Compartments of Mouse Bone Marrow DuRING the SECONDARY Response to SRBC

\begin{tabular}{cccc}
\hline $\begin{array}{c}\text { Source of } \\
\text { bone marrow } \\
\text { cells }\end{array}$ & \multicolumn{3}{c}{ PFC $/ 10^{7}$ viable nucleated cells } \\
\cline { 2 - 4 } & IgM & IgG & IgA \\
\hline Femur & $820^{b}$ & 4914, & 1568 \\
& $(521-1291)$ & $(3294-7329)$ & $(1004-2449)$ \\
Tibia & 1037 & 4648 & 1935 \\
& $(520-2068)$ & $(2049-10,541)$ & $(1251-2991)$ \\
Humerus & 1640 & 4971 & 1882 \\
& $(695-3868)$ & $(2618-9439)$ & $(870-4070)$ \\
Rib & 1667 & 5795 & 2137 \\
& $(793-3505)$ & $(2772-12,118)$ & $(1040-4389)$ \\
\hline
\end{tabular}

a Mice were primed with $10^{7} \mathrm{SRBC}$ iv and boosted with $4 \times 10^{8} \mathrm{SRBC}$ iv 4 mo later. PFCassay was done 7 days after the booster injection.

${ }^{b}$ Geometric mean and $95 \%$ confidence limits.

- Marrow cells from ribs were obtained by gently breaking the ribs with mortar and pestle. Cells were separated from bone fragments by squeezing the suspension through a nylon-gauze filter with $30 \mu \mathrm{m}$ openings.

was still unable to compensate for the absence of the spleen by an increased PFC activity. It was even found that PFC activity in the bone marrow of these splenectomized mice was completely absent, whereas in the bone marrow of sham-splenectomized mice PFC were found of all three antibody classes (Fig. 1). The 2-ME sensitive and 2-ME resistant antibody titres in the splenectomized mice were also very deficient (Fig. 2), demonstrating that other lymphoid organs did not compensate for the absence of spleen-derived antibodies.

The influence of splenectomy upon secondary PFC activity in the bone marrow was studied in three groups of mice primed with $10^{7} \mathrm{SRBC}$ iv. One group was sham-splenectomized 2 mo before priming, and again 3 mo thereafter. The second group was splenectomized 2 mo before, and sham-splenectomized 3 mo after priming, and in the third group these operations were reversed. Four months after priming all mice were boosted with $4 \times 10^{8} \mathrm{SRBC}$ iv and the development of the secondary response was followed in spleen, bone marrow, peripheral lymph nodes (inguinal, axillary, and brachial), mesenteric lymph node, Peyer's patches (only the patches of the small intestine were used), thymus, and blood. Of all these organs tested a significant PFC activity was found only in spleen and bone marrow. Bone marrow PFC occurred only in mice which were two times sham-splenectomized or splenectomized 1 mo before the booster injection (Fig. 3). During this secondary response the PFC activity in the bone marrow of mice two times shamsplenectomized rose to a level which surpassed the level in the spleen at about the seventh day for IgM-PFC as well as for IgG- and IgA-PFC. The bone marrow PFC activity of mice splenectomized 1 mo before the booster injection rose to a higher level than in the former group of mice (Fig. 3). In a previous paper evidence was presented that this higher PFC activity is probably due to the absence of spleen-derived antibodies (1). In the bone marrow of mice splenectomized before priming with $10^{7} \mathrm{SRBC}$ iv no significant $\operatorname{IgM}-, \operatorname{IgG}$, and $\operatorname{IgA}-\mathrm{PFC}$ activitv 


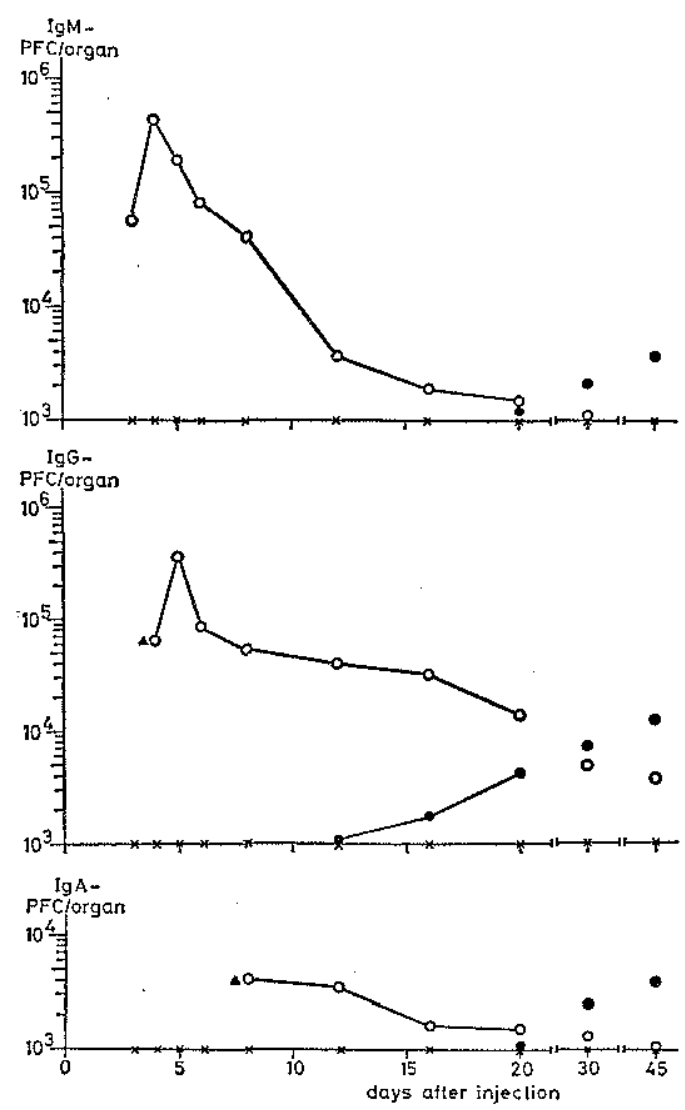

Frg. 1. Number of PFC in spleen $(O)$ and bone marrow $(\bullet)$ of mice sham-splenectomized 7 mo beiore immunization with $4 \times 10^{8} \mathrm{SRBC}$ iv. In the bone marrow $(X)$ of mice splenectomized 7 mo before injection of $4 \times 10^{8} \mathrm{SRBC}$ iv no significant $\mathrm{PFC}$ activity was found at any time after immunization. Where $(\boldsymbol{\Delta})$ is added to an experimental point, the number of IgG-PFC or IgA-PFC above the number of IgM-PFC was not significant.

could be demonstrated during the secondary response (Fig. 3). In these mice 2-ME sensitive and 2-ME resistant antibody titeres during the secondary response were greatly impaired as compared with the serum antibody titres of the other two groups of mice (Fig. 4). Since these secondary response titres were as low as primary response titres of splenectomized mice (Fig. 2) it can be concluded that splenectomy before priming with $10^{7} \mathrm{SRBC}$ iv completely prevented the develoment of a secondary type antibody response after boosting.

In another experiment it was investigated whether this influence of splenectomy before priming on the secondary response can be overcome by using a higher antigen dose for primary immunization. In this experiment splenectomized and sham-splenectomized mice were immunized with $4 \times 10^{8} \mathrm{SRBC}$ iv 2 mo after surgery. Four months later both groups of mice were boosted with a second injection of $4 \times 10^{8} \mathrm{SRBC}$ iv and the development of the secondary PFC response of the bone marrow was followed. In contrast to the experiment in which the mice were primed with $10^{7} \mathrm{SRBC}$, splenectomized mice now showed a clear IgM-, IgG-, and IgA-PFC activity in the bone marrow (Fig. 5). However, the PFC 

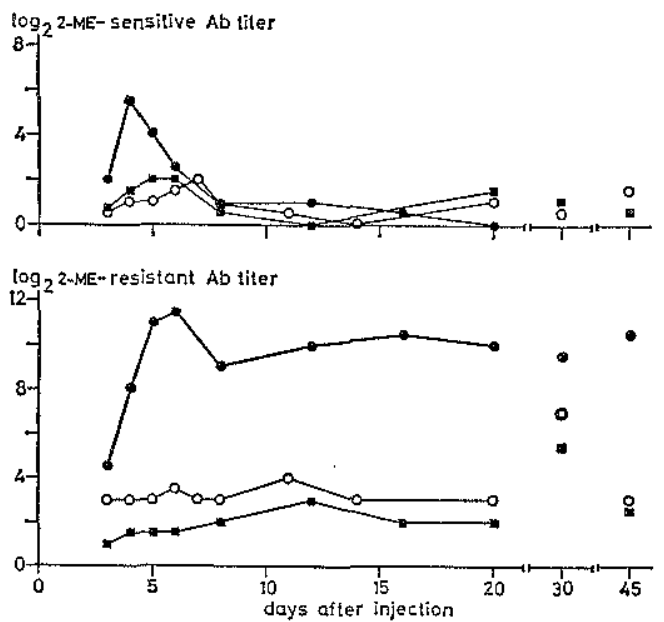

Frg. 2. 2-ME-sensitive and 2-ME-resistant antibody titres in the sera of mice sham-splenectomized ( or splenectomized ( ) 7 mo before immunization with $4 \times 10^{8} \mathrm{SRBC}$ iv. The sera were obtained from the same mice used to determine PFC activity in spleen and bone marrow (Fig. 1). For comparison, the secondary response of mice splenectomized before priming with $10^{7} \mathrm{SRBC}$ iv (O) is given.

activity in the bone marrow of sham-splenectomized mice, which was shown to be impaired by the presence of the spleen (Fig. 3) was higher throughout the experiment. Therefore priming with $4 \times 10^{8}$ SRBC cannot completely overcome the influence of splenectomy before priming upon secondary $\mathrm{PFC}$ activity in the bone marrow.

\section{Effects of Splenectomy on the Appearance of $B$ and $T$ Memory Cells in the Bone Marrow}

The development of PFC in mouse bone marrow during the secondary response to $\mathrm{SRBC}$ was previously concluded to be dependent on the presence of specific $B$ and $T$ memory cells in the bone marrow (3). Therefore we also studied the effects of splenectomy before the priming antigen injection upon the appearance of $B$ and $T$ memory cells in the bone marrow. Since it was previously demonstrated that after immunization with $4 \times 10^{8} \mathrm{SRBC}$ iv, B memory cells do not only appear in spleen and bone marrow, but also in peripheral lymph nodes, mesenteric lymph node, Peyer's patches, thymus, and blood (3), the influence of splenectomy upon the appearance of B memory cells was also studied in these organs. The appearance of $\mathrm{B}$ and $\mathrm{T}$ memory cells was studied by means of cell transfer experiments performed 4 mo after primary inmunization of five groups of mice. One group was sham-splenectomized and not inmunized. Another group was splenectomized and primed with $10^{7} \mathrm{SRBC}$ iv. The third group was sham-splenectomized and immunized with $10^{7}$ SRBC iv. The fourth group of nice was splenectomized before immunization with $4 \times 10^{8} \mathrm{SRBC}$ iv. The last group was sham-splenectomized and primed with $4 \times 10^{8}$ SRBC iv.

Transfer of $2 \times 10^{7}$ viable bone marrow cells from nonimmunized shamsplenectomized mice into lethally irradiated mice challenged with $5 \times 10^{8} \mathrm{SRBC}$ 
$\lg M-$
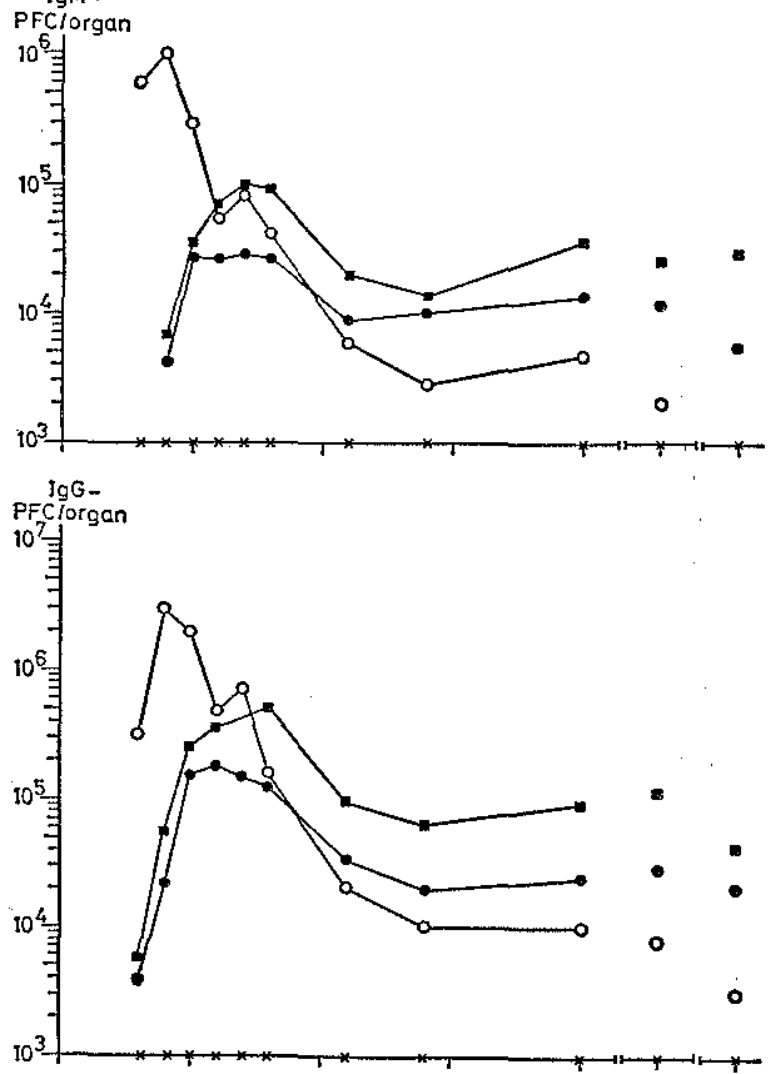

$\operatorname{Ig} A-$

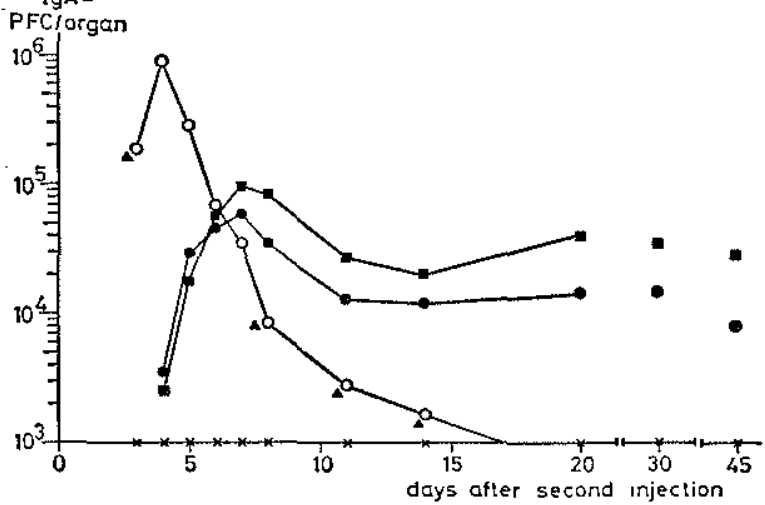

FIc. 3. Number of PFC in mouse spleen and bone marrow after two injections of SRBC iv. Spleen (O) and bone marrow ( ) of mice sham-splenectomized before priming and before boosting. Bone marrow ( $\mathbf{a})$ of mice sham-splenectomized before priming and splenectomized before the booster injection. In the bone marrow $(X)$ of mice splenectomized before first and sham-splenectomized before second immunization no significant PFC activity was found at any time after second antigen injection. In all groups of mice, no significant PFC activity was found in peripheral lymph nodes, mesenteric lymph node, Peyer's patches, thymus, and blood. All mice were primed with $10^{7} \mathrm{SRBC}$ iv and boosted with $4 \times 10^{8} \mathrm{SRBC}$ iv 4 mo later. Where (A) is added to an experimental point, the number of IgA-PFC above the number of IgM$\mathrm{PFC}$ was not significant. 

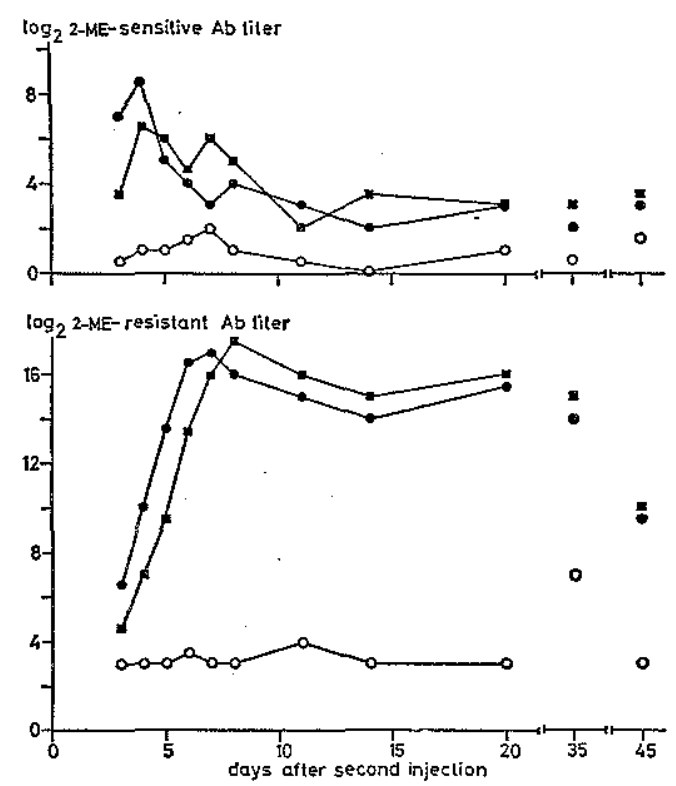

FIG. 4. 2-ME-sensitive and 2-ME-resistant serum antibody titres after two injections of SRBC iv. The sera were obtained from the same mice used to determine PFC activity during secondary response (Fig. 3). Mice splenectomized before priming (O), mice splenectomized before the booster injection $(\boldsymbol{\square})$ and mice which were not splenectomized $(\bullet)$.

evoked very small numbers of PFC in the spleen of the recipient mice (Table $2)$. The same result was obtained with bone marrow cells from mice splenectomized before priming with $10^{7} \mathrm{SRBC}$ (Table 3. In contrast, transfer of bone marrow cells from sham-splenectomized primed animals evoked increased numbers of PFC of all antibody classes in the recipient spleen (Table 4). Part of the deficit in bone marrow of the splenectomized and the nonimmunized mice could be corrected by adding $10^{7} \mathrm{CRT}$ at the moment of cell transfer. This indicates that splenectomy interferes with the appearance of $\mathrm{T}$ memory cells in the bone marrow. As shown in Table 4, transfer of bone marrow cells from mice sham-splenectomized before priming with $10^{7} \mathrm{SRBC}$ iv together with $10^{7} \mathrm{CRT}$ gave an increased IgM-, IgG-, and IgA-PFC response in the recipient spleen as compared with transfer of bone marrow cells from nonimmune mice and CRT (Table 2). The response evoked by bone marrow cells from the splenectomized primed mice together with CRT (Table 3 ) was as low as the response evoked by bone marrow cells from nonimmunized mice and CRT (Table 2). Thus splenectomy before priming with $10^{7} \mathrm{SRBC}$ iv not only interfered with the appearance of $T$ memory cells, but also with the appearance of $B$. memory cells in the bone marrow. Although both $\mathrm{B}$ and $\mathrm{T}$ memory cells appeared in the bone marrow of mice sham-splenectomized before priming with $10^{7}$ SRBC the number of $\mathrm{T}$ memory cells was not optimal for a maximal PFC response since addition of $10^{7}$ CRT to these bone marrow cells improved the PFC response in the recipient spleen (Table 4). Four months after immunization of splenectomized mice with $4 \times 10^{8} \mathrm{SRBC}$ iv the bone marrow of these mice contained both $\mathrm{B}$ and $\mathrm{T}$ memory cells as shown by comparing Tables 2 and 5 . Bone marrow cells from sham-splenectomized mice immunized with $4 \times 10^{8} \mathrm{SRBC}$ iv evoked a some- 
IgM-

PFClbone marrow

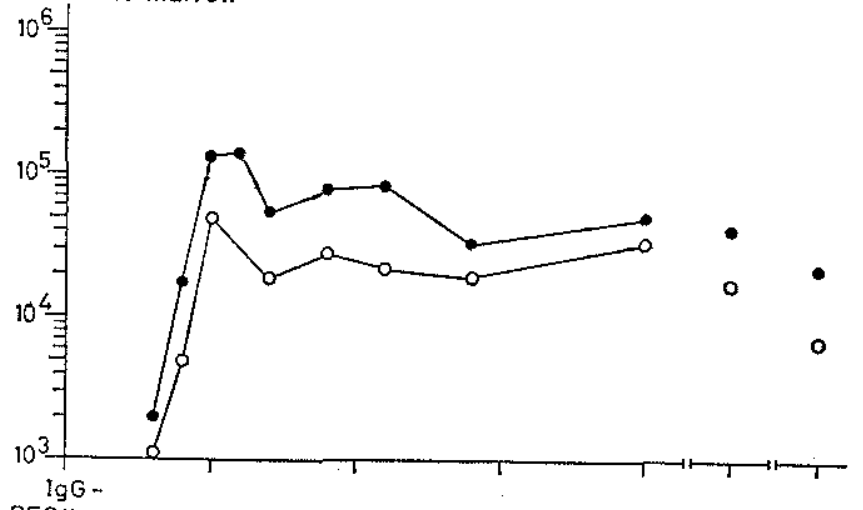

PFClbone marrow

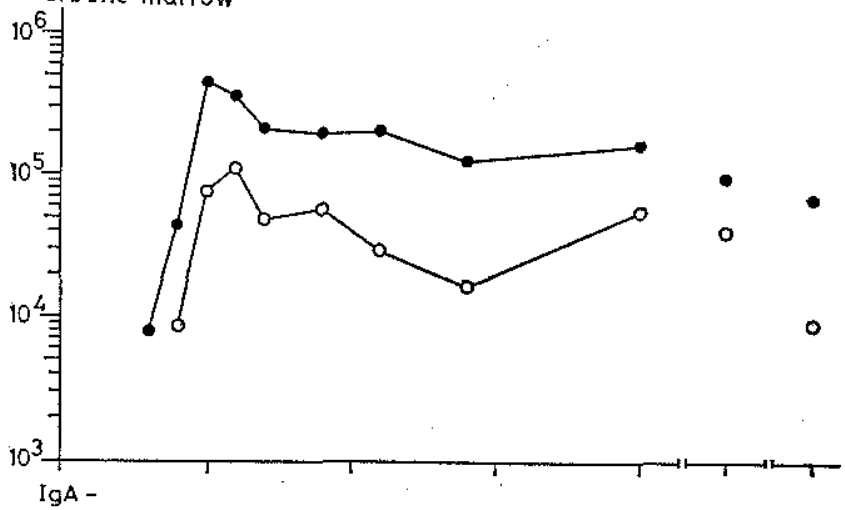

IgA -

PFC/bone marrow

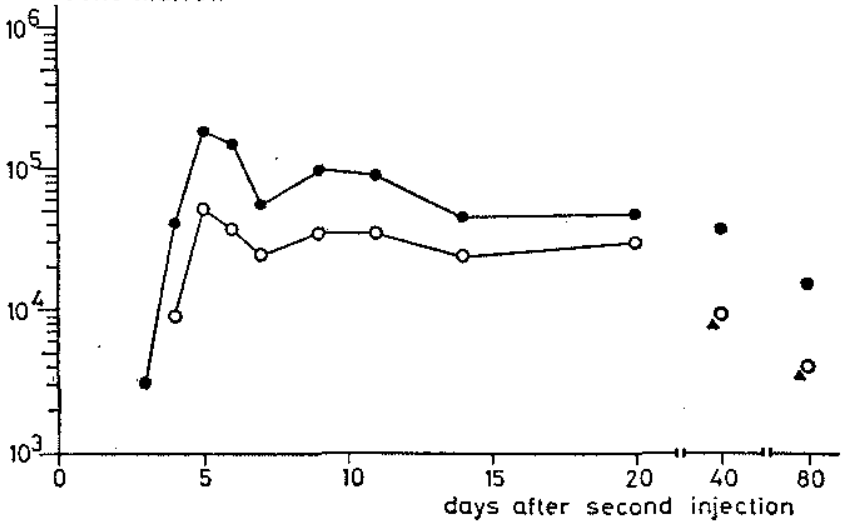

Fig. 5. Number of $\mathrm{PFC}$ in mouse bone marrow after two injections of $4 \times 10^{8} \mathrm{SRBC}$ iv. The second injection was given 4 mo after the first. Mice were sham-splenectomized $(\bullet)$ or splenectomized (O) before the first antigen-injection. Where (A) is added to an experimental point, the number of IgA-PFC above the number of $\operatorname{IgM-PFC}$ was not significant.

what higher PFC response in the recipient spleen (Table 6) than did bone marrow cells from splenectomized mice immunized with that antigen dose (Table 5). This was found after transfer of bone narrow cells alone as well as after transfer of bone marrow cells together with CRT. 
TABLE 2

Adoptive PFC RESPONSE BY CELls FROM VARIOUS LyMphom ORGaNS OF Nonprimed Sham-Splenectomized Mice

\begin{tabular}{|c|c|c|c|c|}
\hline \multirow[t]{2}{*}{ Cells transferred from ${ }^{a}$} & \multirow{2}{*}{$\begin{array}{c}\text { CRT } \\
\text { added }^{b}\end{array}$} & \multicolumn{3}{|c|}{$\mathrm{PFC} /$ recipient spleen $\left(\times 10^{3}\right)^{c}$} \\
\hline & & $\operatorname{IgM}$ & $\operatorname{IgG}$ & IgA \\
\hline Spleen & - & 209 & 901 & 190 \\
\hline Spleen & $10^{7}$ & 262 & 1406 & 301 \\
\hline Bone marrow & - & 0.7 & 0.4 & 0.0 \\
\hline Bone marrow & $10^{7}$ & 26 & 71 & $2(\mathrm{~ns})^{d}$ \\
\hline Peripheral lymph nodes & $10^{7}$ & 455 & 1796 & 278 \\
\hline Mesenteric lymph node & $10^{7}$ & 490 & 2300 & 321 \\
\hline Peyer's patches & $10^{7}$ & 162 & 381 & 12 (ns) \\
\hline Thymus & $10^{3}$ & 0.2 & 0.0 & 0.0 \\
\hline Blood & $10^{7}$ & 3 & 25 & 2 \\
\hline- & $10^{7}$ & $<0.2$ & $<0.2$ & $<0.2$ \\
\hline
\end{tabular}

a Viable rucleated cells $\left(2 \times 10^{7}\right)$ or $0.25 \mathrm{ml}$ blood were transferred 6 mo after sham-splenectomy.

${ }^{3}$ Corticosteroid resistant thymocytes (CRT) were obtained from 6-wk-old mice ip injected with Dexamethasone-sodium-phosphate 2 days previously.

- Arithmatic mean of the values obtained from five recipient mice. PFC-assay was done 7 days after cell transfer.

${ }^{d}$ There was no significant difference between the number of PFC in the direct assay and the number of $\mathrm{PFC}$ in the indirect assay.

The appearance of $B$ memory cells in the other lymphoid organs was studied by transfer of a fixed number of viable nucleated cells together with $5 \times 10^{8}$ $\mathrm{SRBC}$ and $10^{7} \mathrm{CRT}$ into lethally irradiated recipients. By comparison of Tables 2,3 , and 4 it can be seen that splenectomy before immunization with $10^{7} \mathrm{SRBC}$

TABLE 3

Adoptrve PFC Response bX CeLls From Various LyMphoid Organs of Mrce Splenectomized Before Priming with $10^{7}$ SRBC iv

\begin{tabular}{|c|c|c|c|c|}
\hline \multirow[t]{2}{*}{ Cells transferred from ${ }^{a}$} & \multirow{2}{*}{$\begin{array}{c}\text { CRT } \\
\text { added }^{b}\end{array}$} & \multicolumn{3}{|c|}{$\mathrm{PFC} /$ recipient spleen $\left(\times 10^{3}\right)^{c}$} \\
\hline & & IgM & IgG & $\operatorname{Ig} A$ \\
\hline Bone marrow & - & 0.6 & 0.6 & $0.2(\mathrm{~ns})^{d}$ \\
\hline Bone marrow & $10^{7}$ & 33 & 87 & 6 (ns) \\
\hline Peripheral lymph nodes & $10^{7}$ & 261 & 2240 & 170 \\
\hline Mesenteric lymph node & $10^{7}$ & 519 & 1887 & 401 \\
\hline Peyèr's patches & $10^{7}$ & 246 & 644 & 35 (ns) \\
\hline Thymus & $10^{7}$ & 0.3 & 0 & 0 \\
\hline Blood & $10^{7}$ & 6 & 21 & 4 \\
\hline- & $10^{7}$ & $<0.2$ & $<0.2$ & $<0.2$ \\
\hline
\end{tabular}

Viable nucleated cells $\left(2 \times 10^{7}\right)$ or $0.25 \mathrm{ml}$ blood were transferred 4 mo after iv priming of splenectomized mice with $10^{7} \mathrm{SRBC}$.

${ }^{b}$ Corticosteroid resistant thymocytes (CRT) were obtained from 6 -wk-old mice ip injected with Dexamethasone-sodium-phosphate 2 days previously.

- Arithmatic mean of the values obtained from five recipient mice. PFC-assay was done 7 days after cell transfer.

${ }^{d}$ There was no significant difference between the number of PFC in the direct assay and the number of $\mathrm{PFC}$ in the indirect assay. 
TABLE 4

Adoptive PFC Response by Cells from Vartous Lymphoid Organs of Mrce Sham-Splenectomized Before Priming with $10^{7}$ SRBC iv

\begin{tabular}{|c|c|c|c|c|}
\hline \multirow[t]{2}{*}{ Ceils transferred from ${ }^{a}$} & \multirow{2}{*}{$\begin{array}{c}\text { CRT } \\
\text { added }^{b}\end{array}$} & \multicolumn{3}{|c|}{ PFC $/$ recipient spleen $\left(\times 10^{3}\right)^{c}$} \\
\hline & & $\operatorname{IgM}$ & IgG & $\operatorname{IgA}$ \\
\hline Spleen & - & 1823 & 14,468 & 1992 \\
\hline Spleen & $10^{7}$ & 2222 & 17,189 & 1574 \\
\hline Bone marrow & - & 178 & 396 & 104 \\
\hline Bone marrow & $10^{7}$ & 290 & 1498 & 248 \\
\hline Peripheral lymph nodes & $10^{7}$ & 533 & 9218 & 463 \\
\hline Mesenteric lymph node & $10^{7}$ & 1540 & 16,585 & 1315 \\
\hline Peyer's patches & $10^{7}$ & 418 & 1649 & 537 \\
\hline Thymus & $10^{7}$ & 16 & 142 & 25 \\
\hline Blood & $10^{7}$ & 37 & 144 & 21 \\
\hline- & $10^{7}$ & $<0.2$ & $<0.2$ & $<0.2$ \\
\hline
\end{tabular}

- Viable nucleated cells $\left(2 \times 10^{7}\right)$ or $0.25 \mathrm{mi}$ blood were transferred 4 mo after iv priming of sham-splenectomized mice with $10^{7} \mathrm{SRBC}$.

${ }^{b}$ Corticosteroid resistant thymocytes (CRT) were obtained from 6-wk-old mice ip injected with Dexamethasone-sodium-phosphate 2 days previously.

- Arithmatic mean of the values obtained from five recipient mice. PFC-assay was done 7 days after cell transfer.

iv prevents the appearance of $\mathrm{B}$ memory cells not only in the bone marrow, but also in peripheral lymph nodes, mesenteric lymph node, Peyer's patches, thymus, and blood. Immunization of splenectomized mice with a dose of antigen as high as $4 \times 10^{8}$ SRBC induced the appearance of IgM-, IgG-, and IgA-B memory cells in the various lymphoid organs. The cells of these organs together with CRT evoked enhanced numbers of IgM-, IgG, and IgA-PFC in the recipient

TABLE 5

Adoptive PFC Response by Cells From Various lymphom Organs of Mice Splenectomized Before Priming with $4 \times 10^{8}$ SRBC iv

\begin{tabular}{|c|c|c|c|c|}
\hline \multirow[t]{2}{*}{ Cells transferred from ${ }^{\alpha}$} & \multirow{2}{*}{$\begin{array}{c}\text { CRT } \\
\text { added }^{b}\end{array}$} & \multicolumn{3}{|c|}{$\mathrm{PFC} /$ recipient spleen $\left(\times 10^{3}\right)^{c}$} \\
\hline & & IgM & IgG & $\operatorname{IgA}$ \\
\hline Bone marrow & - & 64 & 210 & 46 \\
\hline Bone marrow & $10^{7}$ & 194 & 816 & 191 \\
\hline Peripheral lymiph nodès & $10^{7}$ & 1175 & 6488 & 1055 \\
\hline Mesenteric lymph node & $10^{7}$ & 1133 & 10,055 & 1253 \\
\hline Peyer's patches & $10 ?$ & 364 & 2040 & 441 \\
\hline Thymus & $10^{7}$ & 17 & 102 & 36 \\
\hline Blood & $10^{7}$ & 26 & 78 & 20 \\
\hline- & $10^{7}$ & $<0.2$ & $<0.2$ & $<0.2$ \\
\hline
\end{tabular}

c Viable nucleated cells $\left(2 \times 10^{7}\right)$ or $0.25 \mathrm{ml}$ blood were transferred 4 mo after iv priming of splenectomized mice with $4 \times 10^{8}$ SRBC.

${ }^{5}$ Corticosteroid resistant thymocytes (CRT) were obtained from 6-wk-old mice ip injected with Dexamethasone-sodium-phosphate 2 days previously.

${ }^{c}$ Arithmatic mean of the values obtained from five recipient mice. PFC-assay was done 7 days after cell transfer. 
spleen (Tables 2 and 5). These PFC responses were somewhat lower than after transfer of lymphoid cells from sham-splenectomized mice iv immunized with $4 \times 10^{8}$ SRBC (Table 6).

\section{DISCUSSION}

Immunization of mice with SRBC induces the appearance of $\mathrm{B}$ and $\mathrm{T}$ memory cells in the bone marrow (this paper and Ref. 3). B memory cells were found for $\operatorname{IgM}$ as well as for IgG- and IgA-PFC responses. Immunocompetent $B$ cells $(3)$ and $T$ cells $(14,15)$ were also reported to appear "spontaneously" in the bone marrow during adult life. Possibly these $B$ and $T$ cells are longlived memory cells for environmental antigens stimulating the lymphoid system. Autoradiographic studies are consistent with this supposition, since very recently it was shown that in mice essentially no short-lived lymphocytes migrate to the bone marrow $(16,17)$ while both long-lived $B$ and $T$ lymphocytes are normal residents in the marrow (18).

The capacity of mouse bone marrow to show PFC activity during the secondary response to SRBC was previously shown to coincide with the presence of both $\mathrm{B}$ and $\mathrm{T}$ memory cells in situ (3.) Therefore we suggested antibody formation in mouse bone marrow to be a memory-dependent phenomenon (3). The splenectomy experiments reported in this paper favour this idea. Splenectomy before priming with $10^{7} \mathrm{SRBC}$ iv not only interferes with the appearance of $\mathrm{B}$ and $\mathrm{T}$ memory cells (Table 7 ) but also prevents PFC activity in the bone marrow of these mice after the booster injection (Fig. 3). Priming of splenectomized mice with $4 \times 10^{8}$ SRBC did induce the appearance of $\mathrm{B}$ and $\mathrm{T}$ memory cells in the bone marrow (Table 7 ). This again coincides with the

\section{TABLE 6}

Adoptive PFC Response by Cells from Various Lymphoid Organs of Mice Sham-Splenectomized Before Priming with $4 \times 10^{8}$ SRBC iv

\begin{tabular}{|c|c|c|c|c|}
\hline \multirow[t]{2}{*}{ Cells transferred from ${ }^{a}$} & \multirow{2}{*}{$\begin{array}{c}\text { CRT } \\
\text { added }^{b}\end{array}$} & \multicolumn{3}{|c|}{$\mathrm{PFC} /$ recipient spleen $\left(\times 10^{3}\right)^{\mathrm{c}}$} \\
\hline & & $\operatorname{IgM}$ & IgG & $\operatorname{IgA}$ \\
\hline Spleen & - & 3213 & 12,987 & 1456 \\
\hline Spleen & $10^{7}$ & 2759 & 9752 & 1339 \\
\hline Bone marrow & - & 176 & 587 & 136 \\
\hline Bone marrow & $10^{7}$ & 459 & 1459 & 406 \\
\hline Peripheral lymph nodes & $10^{7}$ & 1179 & 11,022 & 931 \\
\hline Mesenteric lymph node & $10^{7}$ & 5183 & 19,493 & 2543 \\
\hline Peyer's patches & $10^{7}$ & 1031 & 3905 & 1240 \\
\hline Thymus & $10^{7}$ & 31 & 188 & 64 \\
\hline Blood & $10^{7}$ & 56 & 159 & 43 \\
\hline- & $10^{7}$ & $<0.2$ & $<0.2$ & $<0.2$ \\
\hline
\end{tabular}

a Viable nucleated cells $\left(2 \times 10^{7}\right)$ or $0.25 \mathrm{ml}$ blood were transferred 4 mo after iv priming of sham-splenectomized mice with $4 \times 10^{8} \mathrm{SRBC}$.

${ }^{b}$ Corticosteroid resistant thymocytes (CRT) were obtained from 6-wk-old mice ip injected with Dexamethasone-sodium-phosphate 2 days previously.

'Arithmatic mean of the values obtained from five recipient mice. $\mathrm{PFC}$-assay was done 7 days after cell transfer. 
TABLE 7

Appearance of B and T Memory Cells in the Bone Marrow of Mice Splenectomized or Sham-SPlenectomized Before Priming with SRBC (Summary of Results of TABles 2-6)

\begin{tabular}{lrc}
\hline \multicolumn{1}{c}{ Surgery } & Priming dose & $\begin{array}{c}\text { B and T } \\
\text { memory cells }\end{array}$ \\
\hline Splenectomy & $10^{7} \mathrm{SRBC}$ & $-{ }^{a}$ \\
Sham-splenectomy & $10^{7} \mathrm{SRBC}$ & $+^{b}$ \\
Splenectomy & $4 \times 10^{8} \mathrm{SRBC}$ & $+^{c}$ \\
Sham-splenectomy & $4 \times 10^{8} \mathrm{SRBC}$ & $++^{b}$ \\
\hline
\end{tabular}

a No significantly increased response as compared with the bone marrow cells from nonprimed mice.

${ }^{b}$ Greatly increased response.

- Moderately increased response

capacity to exhibit PFC activity in the bone marrow during the secondary response (Fig. 5).

Using isotopic labeling techniques it was demonstrated that the great majority of the bone marrow lymphocytes are generated in situ $(19,20)$. These small lymphocytes have a very rapid turnover: more than $80 \%$ become labeled after repeated ip injections of tritiated thymidine $\left({ }^{3} \mathrm{HTdR}\right)$ for 4 days $(19,21)$. Theta positive cells $(14,18)$ as well as cells which can perform $\mathrm{T}$ cell functions $(22,23)$ are found to be very scarce in mouse bone marrow. About $50 \%$ of the marrow small lymphocytes show varying amounts of surface immunoglobulins (Ig) (24). The lymphocyte-like cells which lack theta-antigen, readily demonstrate Ig or complement receptors on their surface are suggested to be predominantly immature B lymphocytes $(21,25)$. Osmond and Nossal (21) recently studied the appearance of surface-Ig on short-lived bone marrow lymphocytes in mice. These authors obtained strong evidence that small lymphocytes in the marrow are initially Ig-negative but rapidly express increasing amounts of surface-Ig during differentiation and proliferation. Basten and co-workers (26) using a radioactively labeled antigen "suicide" technique whereby cells binding the antigen are inactivated, have shown that, in conditions in which thymocytes and spleen B cells are inactivated, bone marrow lymphocytes are unaffected. This could be interpreted as suggesting that maturation to the antigenbinding stage takes place predominantly after the cells have migrated from the marrow. This line of evidence is consistent with the hypothesis of Nieuwenhuis and Keuning (6) about the origin of the B cell system. Based upon a series of experiments with rabbits they suggest that the $B$ cell system is morphologically represented by all the follicular structures (including the marginal zone) in the body. The population of lymphoid cells in these follicular structures is of dual origin: (1) directly bone marrow-derived $\left(B_{1}\right.$ cells) and involved in the formation of germinal centres; (2) indirectly-via germinal centre reactions-bone marrowderived $\left(\mathrm{B}_{2}\right.$ cells $)$ and represented in the marginal zone cell system as antibody-forming cell precursors involved in the formation of plasma cells. This population of $\mathrm{B}_{2}$ cells would also include the $\mathrm{B}$ memory cells which are found to contribute to the recirculating lymphocyte pool $(27,28)$ and seed to the bone marrow (Table 7). Thus mouse bone marrow seems to contain two popu- 
lations of B cells: (1) probably immunoincompetent, short-lived cells, differentiated in situ; (2) immunocompetent B memory cells, derived from secondary lymphoid organs.

It is of interest that splenectomy before priming with $10^{7} \mathrm{SRBC}$ iv not only interfered with the appearance of $\mathrm{B}$ memory cells in the bone marrow, but also with their appearance in other lymphoid organs, including the thymus (compare Tables 2-4). Apparently the appearance of B memory cells in the lymphoid organs throughout the body is caused by seeding from the spleen and not due to generation of these memory cells in these organs in situ.

There is little doubt that memory to thymus-dependent antigens is carried not only by $\mathrm{B}$ cells, but also by $\mathrm{T}$ cells. Limiting dilution experiments suggest that $T$ cell memory constitutes an increase in the number of $T$ cells (27). This view is supported by experiments reported here and by the observation that memory to the thymus-dependent antigen TIGAL (a synthetic polypeptide) is associated with increased numbers of specific antigen-binding $T$ cells in the spleen (29). Experiments in which thymocytes were transferred into lethally irradiated recipients together with specific antigen show that under these circumstances $\mathrm{T}$ memory cells can be generated in the spleen $(30,31)$. However, such experiments do not provide evidence that under more physiological conditions $\mathrm{T}$ memory cells are also generated in secondary lymphoid organs. In our experiments it was observed that splenectomy before priming with $10^{3}$ SRBC iv can completely prevent the appearance of $T$ memory cells in the bone marrow, thus providing evidence that $T$ memory cells indeed are generated in secondary lymphoid organs, as has been hypothesized by Miller and Mitchell (9). It would be of great interest to investigate in this experimental system whether such $\mathrm{T}$ memory cells are also absent in the recirculating lymphocyte pool.

Experiments in which the DNA-synthesis of adoptively transferred thymocytes in the spleen of irradiated mice were correlated with their helper cell activity suggest that $\mathrm{T}$ cell mitosis is involved in the generation of $\mathrm{T}$ memory cells (31). 'Light and electron microscopic studies in our laboratory suggest that this proliferation and maturation process in the spleen occurs in the periarteriolar lymphatic sheath around and in close contact with interdigitating cells (32).

The effect of splenectomy upon the appearance of $B$ and $T$ memory cells could be partly overcome by using an antigen dose as high as $4 \times 10^{8} \mathrm{SRBC}$ (Table 7). It is known that small numbers of iv inoculated ${ }^{51} \mathrm{Cr}$-labeled SRBC can reach the gut (33). Although immunization with $4 \times 10^{8} \mathrm{SRBC}$ iv did not evoke the appearance of PFC in lymph nodes and Peyer's patches (1), it is possible that this antigen dose did induce the generation of $\mathrm{B}$ and $\mathrm{T}$ memory cells in these organs, since it is known that the development of $\mathrm{B}$ and $\mathrm{T}$ cell memory requires only small amounts of antigen $(2,34,35)$. Therefore a plausible explanation for the appearance of $B$ memory cells (in bone marrow, peripheral lymph nodes, mesenteric lymph node, Peyer's patches, thymus, and blood) and $\mathrm{T}$ memory cells (at least in the bone marrow) in mice splenectomized before priming with $4 \times 10^{8} \mathrm{SRBC}$ iv is, that these memory cells are induced by small amounts of antigen reaching lymph nodes and gut-associated lymphoid tissue. However, an alternative explanation has also to be considered. It cannot be excluded that the bone marrow is in principle, like spleen and 
lymph nodes, able to generate B memory cells, but that the generation of $B$ memory cells in the bone marrow requires a higher antigen dose. Likewise it would be possible that high doses of antigen can induce the generation of $T$ memory cells within the thymus. The presence of both interdigitating cells (36) and long-lived, potentially recirculating $T$ lymphocytes $(37)$ in the thymic medulla is consistent with this supposition.

Cell transfer experiments reported in a previous paper (3) showed that thymocytes cannot enhance the adoptive PFC response of immune spleen cells or immune bone marrow cells. From these experiments it was concluded that in both spleen and bone marrow the number of $\mathrm{T}$ memory cells was enough to give a maximal PFC response. In the present experiments CRT were used as a source of $T$ cells to supplement lymphoid cell suspensions. Such cells are found to be better helper cells than normal thymocytes (38). We confirmed these results by showing that in contrast to normal thymocytes (3), CRT could enhance the adoptive PFC response of immune bone marrow cells (Tables 4-6). Apparently the number of $\mathrm{T}$ cells in the bone marrow of immune mice is not optimal for a maximal adoptive $\mathrm{PFC}$ response. This relative deficit of $\mathrm{T}$ cells was observed regardless of the origin of $\mathrm{B}$ and $\mathrm{T}$ memory cells, spleen-derived (Table 4) or derived from other lymphoid organs (Table 5). In spite of a different $\mathrm{B} / \mathrm{T}$ ratio in these various lymphoid organs (39) and a preponderance of $\mathrm{T}$ cells in the recirculating lymphocyte pool $(28,39)$ the relative deficit of $\mathrm{T}$ cells in the bone marrow seemed to be the same. Apparently the bone marrow determines the amount of, or the ratio between, the $B$ and $T$ cells which enter.

\section{ACKNOWLEDGMENTS}

We are very indebted to Prof. Dr. O. Vos, Dr. W. Hijmans, Dr. O. B. Zaalberg, and Dr. G. H. Blijham for their discussion of the manuscript. We also express our thanks to Dr. O. B. Zaalberg for supplying the rabbit anti-mouse-IgG serum and to Dr. J. Veldkamp for the generous gift of the rabbit anti-mouse-IgA serum. This investigation was supported by the Netherlands Foundation for Medical Research (FUNGO).

\section{REFERENCES}

1. Benner, R., Meima, F., van der Meulen, G. M., and van Muiswinkel, W. B., Immunology 26, 247, 1974.

2. Benner, R., Meima, F., van der Meulen, G. M., and van Ewijk, W., Immunology 27, 747, 1974.

3. Benner, R., Meima, F., and van der Meulen, G. M., Cell Immunol. 13, 95, 1974.

4. Thorbecke, G. J., In "Lymphatic Tissue and Germinal Centers in Immune Response" (L. Fiore-Donati and M. G. Hanna, Eds.), pp. 83-92. Plenum Press, New York, 1969.

5. Durkin, H. G., and Thorbecke, G. J., J. Immunol. 106, 1079, 1971.

6. Nieuwenhuis, P., and Keuning, F. J., Immunology 26, 509, 1974

7. Duhamel, G., La Presse Med. 76, 1947, 1968.

8. Rywlin, A. M., Ortega, R. S., and Dominguez, C. J., Blood 43, 389, 1974.

9. Miller, J. F. A. P., and Mitchell, G. F., Transplant. Rev. 1, 3, 1969.

10. Mishell, R. I., and Dutton, R. W., J. Exp. Med. 126, 423, 1967.

11. Böyum. A., Scan. J. Clin. Lab. Invest. Suppl. 97, 77, 1968.

12. Majoor, G. D., van't Veer, M. B., and Zaalberg, O. B., J. Immunol. Methods, in press.

13. Chervenick, P. A., Boggs, D. R., Marsh, J. C., Cartwright, G. E., and Wintrobe, M. M., Amer. J. Physiol. 215, 353, 1968.

14. Waksman, B. H., Raff, M. C., and East, J., Clin. Exp. Immunol. 11, 1, 1972.

15. Phillips-Quagliata, J. M., Wertenbaker, C., Bensinger, D. O., and Quagliata, F., Cell. Immunol. 4, 134, 1972. 
16. Joel, D. D., Hess, M. W., and Cottier, H., J. Exp. Med. 135, 907, 1972.

17. Röpke, C., and Everett, N. B., Cell Tissue Kinet. 7, 137, 1974.

18. Röpke, C., Hougen, H. P., and Everett, N. B., Cell. Immunol. 15, 82, 1975.

19. Everett, N. B., and Caffrey, R. W., In "The Lymphocyte in Immunology and Haemopoiesis" (J. M. Yoffey, Ed.) pp. 108-119. Edward Arnold, London, 1967.

20. Osmond, D. G., In "Proceedings of the Sixth Leukocyte Culture Conference" (M. Roy Schwarz, Ed.), pp. 3-32. Academic Press, New York, 1972.

21. Osmond, D. G., and Nossal, G. J. V., Cell. Immunol. 13, 132, 1974.

22. Youdim, S., Stutman, O., and Good, R. A., Cell. Immmol. 8, 395, 1973.

23. Claman, H. N., Cell. Immunol. 13, 484, 1974.

24. Osmond, D. G., and Nossal, G. J. V., Cell. Immunol. 13, 117, 1974.

25. Stobo, J. D., Rosenthal, A. S., and Paul, W. E., J Exp. Med. 138, 71, 1973.

26. Basten, A., Miller, J. F. A. P., Warner, N. L., and Pye, J., Nature New Biol. 231, 104, 1971.

27. Miller, J. F. A. P., and Sprent, J., J. Exp. Med. 134, 66, 1971.

28. Sprent, J., Cell. Immunol. 7, 10, 1973.

29. Roelants, G., Forni, L., and Pernis, B., J. Exp. Med. 137, 1060, 1973.

30. Mitchell, G. F., and Miller, J. F. A. P., Proc. Nat. Acad. Sci. 59, 296, 1968.

31. Spiesel, S. Z., and Gershon, R. K., Nature New Biol. 238, 271, 1972.

32. van Ewijk, W., Verzijden, J. H. M., van der Kwast, Th. H., and Luijcx-Meijer, S. W. M., Cell Tiss. Res. 149, 43, 1974.

33. Souhami, R. L., Immunology 22, 685, 1972.

34. Cunningham, A. J., and Sercarz, E. E., Eur. J. Immunol. 1, 413, 1971.

35. Niederhuber, J. E., and Möller, E., Cell. Immunol. 6, 407, 1973.

36. Hoefsmit, E. C. M., In "Mononuclear Phagocytes in Immunity, Infection and Pathology" (R. van Furth, Ed.), pp. 129-146. Blackwell Sc. Publ., Oxford, 1975.

37. Blomgren, H., and Andersson, B., Clin. Exp. Immunol. 10, 297, 1972.

38. van Muiswinkel, W. B., Zaalberg, O. B., Majoor, G., Lubbe, F. H., van Soest, P. L., and van Beek, J. J., In "Biological Activity of Thymic Hormones" (D. W. van Bekkum, Ed.), pp. 99-101. Kooyker Sc. Publ., Rotterdam, 1975.

39. Raff, M. C., Transplant. Rev. 6, 52, 1971. 
APPENDIX PUBLICATION $V$ 



\title{
Antibody Formation in Mouse Bone Marrow
}

\section{THE RESPONSE TO THE THYMUS-INDEPENDENT ANTIGEN ESCHERICHIA COLI LIPOPOLYSACCHARIDE}

\author{
R. Benner and A. van Oudenaren \\ Department of Cell Biology and Genetics, Erasmus University, \\ P.O. Box 1738, Rotterdam, The Netherlands.
}

(Received 3rd July 1975; accepted for publication 14th July 1975)

Summary. The occurrence of plaque-forming cells (PFC) in mouse bone marrow was studied during primary and secondary response to the thymus-independent antigen Escherichia coli lipopolysaccharide (LPS). Anti-LPS responses were induced by various doses of LPS.

During the primary response doses of 1 and $10 \mu \mathrm{g}$ LPS intravenously (i.v.) were found to evoke a distinct PFC response in both spleen and bone marrow. The spleen contained the majority of PFC until about 5 days after immunization. In the course of the reaction the number of PFC in the bone marrow rose to a level which equalled or surpassed the level in the spleen. LPS doses of $0.001,0.01$ and $0.1 \mu \mathrm{g}$ i.v. only induced a PFC response in the spleen. Apparently there is a minimal threshold dose of LPS of about $1 \mu \mathrm{g}$ for PFC to appear in the bone marrow.

The secondary response was studied in mice primed with $1 \mathrm{\mu g}$ LPS i.v. and boosted with either $0.001,0.1$ or $10 \mu \mathrm{g}$ LPS i.v. three months later. After each dose tested the PFC activity in the spleen was several times higher than during the primary response. As was observed in the primary response doses of 0.001 and $0.1 \mu \mathrm{g}$ LPS i.v. 
did not evoke a PFC response in the bone marrow. After boosting with $10 \mu \mathrm{g}$ LPS i.v. a significant PFC response was found in spleen, bone marrow, thymus, lymph nodes, Peyer's patches and blood. From about 5 days after the booster injection the number of PFC in the bone marrow exceeded the total number found in all other lymphoid organs. The results are discussed in relation to the bone marrow PFC response to the thymus-dependent antigen sheep red blood cells. To this antigen a clear PFC response in the bone marrow is found only during the secondary response.

\section{INTRODUCTION}

Previous papers of this series on antibody formation in mouse bone marrow dealt with the plaque-forming cell (PFC) response to the thymus-dependent sheep red blood cell antigen (SRBC). After the second injection of SRBC, but not after the first, a very distinct IgM-, lgG- and $\lg A-P F C$ activity was found in the bone marrow (Benner, Meima, van der Meulen and van Muiswinket, 1974). Independent of the booster dose this activity in the bone marrow appeared to rise to a level which surpassed the total level of all the other lymphoid organs (Benner, Meima, van der Meulen and van Ewijk, 1974). Evidence was presented that cells producing anti-SRBC antibodies can be generated within the bone marrow itself (Benner ef al., 1974a). To initiate such a bone marrow PFC response to SRBC, the presence of specific memory cells seems to be required (Benner, Meima and van der Meulen, 1974; Benner and van Oudenaren, 1975). Presence of the spleen was found to be essential for these memory cells to appear after intravenous (i.v.) priming with moderate doses of SRBC (Benner and van Oudenaren, 1975).

From the literature it is known that the thymus-independent antigen Brucella (Thorbecke, Asofsky, Hochwald and Siskind, 1961), in contrast to thymus-dependent antigens (Thorbecke et al., 1961; Langevoort, Asofsky, Jacobson, de Vries and Thorbecke, 1963), can evoke antibody formation in 
rabbit bone marrow during the primary response. In view of these data it seemed worthwhile to study whether mouse bone marrow can also show PFC activity after primary immunization with a thymus-independent antigen. The antigen chosen was lipopolysaccharide (LPS) from Escherichia coli because antibody formation to this antigen does not require helper $T$ cells (Andersson and Blomgren, 1971; Moller and Michael, 1971) and no evidence has been presented so far that suppressor $T$ cells play a regulatory role in the antibody response to LPS. We found that mouse bone marrow is able to show a distinct anti-LPS activity, even during the primary response.

\section{MATERIALS AND METHODS}

\section{Mice}

(C57BL/Rij $\times$ CBA/Rij)Fl female mice, 16-20 weeks old were used. They were purchased from the Medical Biological Laboratory, Rijswijk, The Netherlands and the Laboratory Animals Centre of the Erasmus University, Rotterdam, The Netherlands.

\section{Antigen and immunization}

LPS from E. coli 055:B5, prepared according the phenol-extraction method (Westphal, Luderitz and Bister, 1952), was obtained from Difco Laboratories, Detroit, Michigan, U.S.A. Before use it was dissolved in a balanced salt solution (BSS), prepared according to Mishell and Dutton (1967).

Mice were immunized by i.v. injection of doses of LPS ranging from $0.001 \mu \mathrm{g}-100 \mu \mathrm{g}$ in $0.5 \mathrm{ml}$ BSS. For secondary immunization mice received an i.v. booster injection 3 months after the first injection.

\section{Splenectomy}

Splenectomy and sham-splenectomy were performed 1 month before injection of LPS. Mice were anaesthetized by an intraperitoneal (i.p.) injection of $70 \mathrm{mg} / \mathrm{kg}$ body weight Nembutal (Abbott S.A., Saint-Rémy-sur-Avre, 
France). The incision was made in the left upper abdomen. For splenectomy the splenic blood vessels were tied in a single suture, then cut and the spleen removed. The incision was closed in two layers. There was no postoperative mortality.

\section{Preparation of cell suspensions}

Cell suspensions were prepared in BSS as described previously (Benner ef al., 1974a). Blood was obtained by cardiac puncture and immediately heparinized $(5 \mathrm{U} / \mathrm{ml})$. Thymi were collected 30 minutes after an i.p. injection with $0.1 \mathrm{ml}$ of a 1 percent solution of carbochrome ink (Gurr Ltd., High Wycombe, Buckinghamshire, England) in BSS. This facilitated differentiation between thymus and adherent lymph nodes in order to avoid contamination of the thymocyte suspension.

\section{Isolation of nucleated cells from peripheral blood}

Nucleated cells were isolated from mouse blood using a modification of the Ficoll-Isopaque system described by Boyum (1968). The Ficoll-Isopaque mixture was obtained by mixing 2 parts Isopaque (Nyegaard \& Co., Oslo, Norway), 3 part's Ficoll (Pharmacia, Uppsala, Sweden) 9 per cent and 2 parts of a 3.5 per cent solution of bovine serum albumin in distilled water. Final density was $1.115 \mathrm{~g} / \mathrm{ml}$. Using this method at least 70 per cent of the nucleated cells was recovered. A Coulter counter model B was used for counting nucleated cells isolated from peripheral blood.

\section{Cell counts}

Viable nucleated cells were counted in a haemocytometer using 0.2 per cent trypan blue in BSS as a diluent.

\section{Irradiation}

The recipient mice received 850 rad whole body irradiation generated in a Philips Muller MG $300 \mathrm{X}$-ray machine. Animals were irradiated in well- 
aerated circular Perspex cages. Physical constants of the irradiation were described previously (Benner ef al., 1974b). Irradiated control mice died in $9-16$ days.

\section{Cell transfer}

Recipients were injected i.v. with the appropriate cell suspension and $5 \mu \mathrm{g}$ LPS within 4 hours after irradiation. On the fourth day all mice were boosted with another $5 \mu \mathrm{g}$ LPS i.p. PFC in the spleen of recipient mice were determined 7 days after cell transfer, since at that moment PFC activity in the recipient spleen is maximal. Each group consisted of 5 mice.

\section{Assay for PFC}

PFC were determined according to the method of Cunningham and Szenberg (1968) with some modifications as described previously (Benner ef al., 1974a, 1975). SRBC coated with LPS were used as targets. Before use LPS ( $1 \mathrm{mg} / \mathrm{ml}$ phosphate buffered saline (PBS), pH 8.0) was boiled for 2 hours at $120^{\circ} \mathrm{C}$. Coating was performed by incubation of $0.3 \mathrm{ml}$ washed and packed SRBC with $0.7 \mathrm{ml}$ of the heat treated LPS solution at $37^{\circ} \mathrm{C}$ for 45 minutes. The coated cells were washed three times in PBS ( $\mathrm{pH} \mathrm{7.2)} \mathrm{before} \mathrm{use} \mathrm{in}$ the PFC assay. The guinea pig complement (Flow Laboratories, Rockville, U.S.A.) used in the plaque assay was previously adsorbed with SRBC, mouse spleen cells and agarose. Adsorption with agarose $(3 \mathrm{mg} / \mathrm{ml}$ guinea pig serum) was found to give excellent removal of anti-LPS antibodies (Zaalberg, personal communication). $\lg G$ and $\lg A$ producing anti-LPS PFC could not be detected at any time after primary and secondary immunization with LPS.

\section{Calculation of total bone marrow PFC activity}

Bone marrow PFC activity was determined in the femoral marrow. From the results of the femoral bone marrow the number of PFC present in the marrow of the whole animal was estimated using the data of Chervenick and coworkers (1968), who showed that in mice one femur contains 5.9 per cent of 
the total marrow. Comparison of the PFC responses evoked by fixed numbers of nucleated bone marrow cells from femur, tibia, humerus, rib and sternum (Table 1) indicated that anti-LPS PFC activity in various compartments of mouse bone marrow is about the same.

\section{TABLE 1}

Comparison of PFC Activity in Various Compartments of Mouse Bone Marrow During the Primary Response to LPS

\begin{tabular}{|c|c|}
\hline $\begin{array}{l}\text { Source of } \\
\text { bone marrow cells }\end{array}$ & $\mathrm{PFC} / 10^{7}$ viable nucleated cells ${ }^{a}$ \\
\hline Femur & $2,492^{b}(1,419-4,376)$ \\
\hline Tibia & $3,415 \quad(1,886-6,181)$ \\
\hline Humerus & $2,937 \quad(1,908-4,521)$ \\
\hline $\operatorname{Rib}^{\mathrm{C}}$ & $2,986 \quad(1,644-5,425)$ \\
\hline Sternum ${ }^{\mathrm{C}}$ & $2,960 \quad(1,746-5,019)$ \\
\hline \multicolumn{2}{|c|}{$\begin{array}{l}{ }^{a} \text { Mice were immunized with } 10 \mu g \text { LPS } \mathrm{i} . \mathrm{v} \text {. PFC-assay was } \\
\text { done } 5 \text { days after immunization. } \\
{ }^{b} \text { Geometric mean and } 95 \% \text { confidence limits. } \\
{ }^{c} \text { Marrow cells from ribs and sternum were obtained by gently } \\
\text { breaking of the bones with mortar and pestle. Cells were. } \\
\text { separated from bone fragments by squeezing the suspension } \\
\text { through a nylon-gauze filter with } 30 \mu \mathrm{m} \text { openings. }\end{array}$} \\
\hline
\end{tabular}

\section{Passive haemagglutination titres}

Anti-LPS antibody titres were assayed by means of a passive haemagglutination technique using a 1 per cent suspension of SRBC coated with LPS. The samples were tested in duplicate with the standard twofold dilution method 
for the presence of 2-mercaptoethanol (2-ME) sensitive and 2-ME resistant antibodies. For determination of $2-M E$ resistant antibody titres, the sera were diluted $v / v$ with 0.2 mol 2-ME. After incubation for 2 hours at room temperature, the sera were titrated according to the standard method.

\section{RESULTS}

\section{Primary response to LPS}

Immunization of mice with $0.001,0.01,0.1,1$ and $10 \mu \mathrm{g}$ LPS i.v. evoked a PFC response in the spleen (Fig. 1 and 2). Independent of the antigen dose peak PFC activity was always found on the fourth day after immunization. After LPS doses of 1 and $10 \mu \mathrm{g}$, but not after lower doses, PFC could also be detected in the bone marrow (Fig. 1). This PFC activity in the bone marrow equalled or surpassed the PFC activity in the spleen at 5 days after immunization. In all other lymphoid organs tested no significant PFC activity was found at any time after a single dose of LPS.

The absence of PFC activity in the bone marrow after $0.1 \mu \mathrm{g}$ or less LPS might be due to the elimination of antigen by the spleen. Therefore we also studied the response to $0.1 \mu \mathrm{\mu g}$ LPS in splenectomized mice. Such mice also showed no significant PFC activity in the bone marrow and no increase in the serum agglutination titre (Fig. 3). After i.v. immunization with doses LPS as low as $0.1 \mathrm{\mu g}$ the spleen seems to be the only site of antibody formation.

\section{Secondary response to LPS}

The secondary response to LPS was studied in mice primed with $1 \mu \mathrm{g}$ LPS i.v. and boosted with either 10,0.1 or $0.001 \mu \mathrm{g}$ LPS i.v. 3 months later. After each dose tested the PFC activity in the spleen (Fig. 4) was much higher than during the primary response to that dose (compare Fig. 1, 2 and 4). Similar 


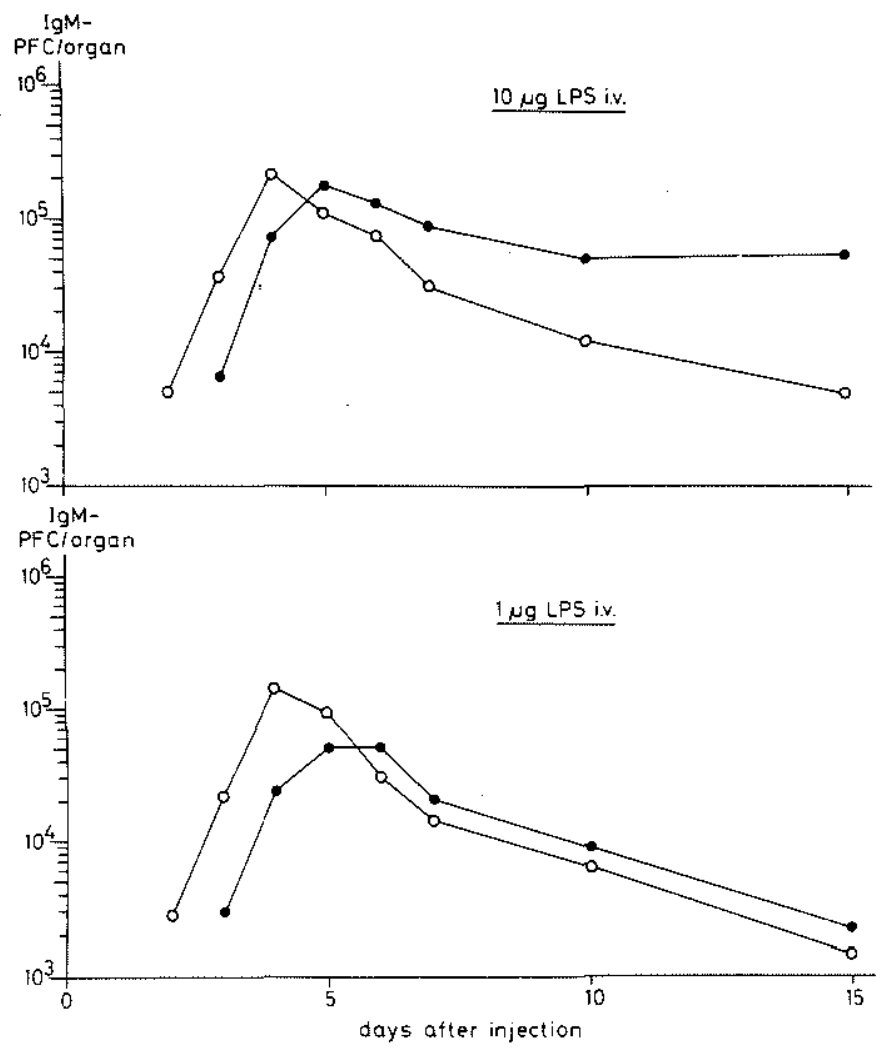

Fig. 1. Number of PFC in mouse spleen (O) and bone marrow (O) after one injection of either 10 or $1 \mu \mathrm{g}$ L.PS i.v. In lymph nodes, Peyer's patches, thymus and blood no significant PFC activity was found at any time after immunization. PFC-assay was done on pooled spleens. Each group consisted of at least 4 mice.

to the primary response after doses of 0.1 and $0.001 \mu \mathrm{g}$ L.PS i.v., these doses did not evoke a PFC response in the bone marrow. After boosting with $10 \mu \mathrm{g}$ LPS i.v. a PFC response was found not only in spleen, but also in bone marrow (Fig. 4), mesenteric lymph node, peripheral lymph nodes, Peyer's patches, thymus and blood (Fig. 5). At about 5 days after this booster injection the number of PFC in the bone marrow exceeded the total number of PFC in all the other 
lymphoid organs. Although only a few PFC were found in the thymus, the response in this organ was more sustained than in lymph nodes, Peyer's patches and blood.

The influence of the priming dose of LPS on the appearance of B memory cells was studied by means of cell transfer experiments. Seven days after transfer of $2 \times 10^{7}$ viable nucleated non-immune spleen cells, bone marrow cells or thymus cells together with $5 \mu \mathrm{g}$ LPS into lethally irradiated mice 49,500, 11,250 , and (a not significant number of) 175 PFC could be detected in the recipient spleen respectively. When the donor mice had been primed with 0.1 , I, 10 or $100 \mu \mathrm{g}$ LPS i.v. 3 months before, spleen cells, bone marrow cells and thymus cells were able to evoke increased anti-LPS PFC responses in the recipient spleen. The relationship between the priming dose and adoptive PFC response was found to be an optimum curve (Fig. 6). Doses LPS of 1 and $10 \mu g$ i.v. gave the best priming; $1 \mu \mathrm{g}$ was used in the experiments on secondary responses described above.

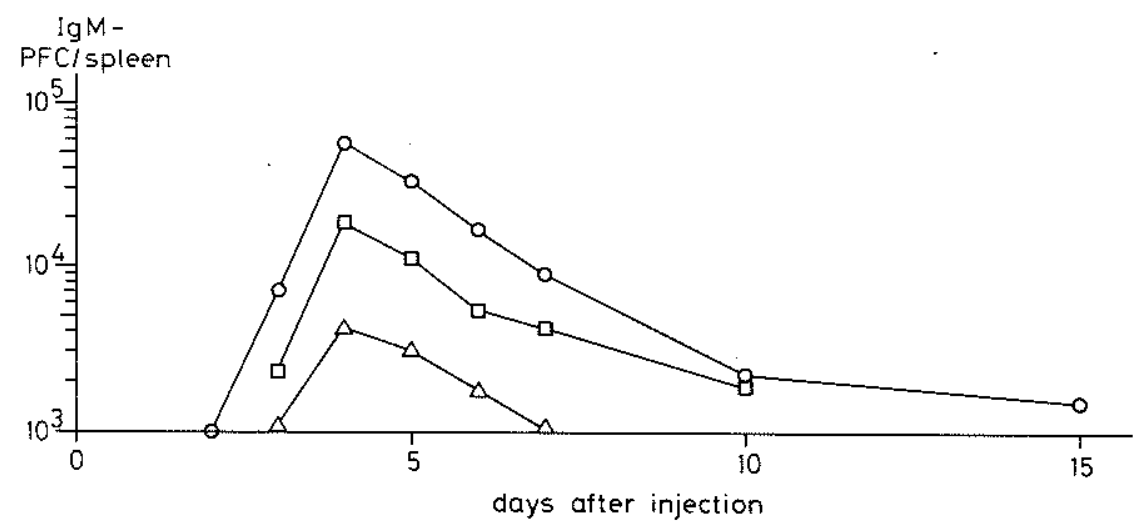

Fig. 2. Number of PFC in mouse spleen after one injection of either 0.1 (O), $0.01(\square)$ or $0.001(\Delta) \mu g$ LPS i.v. In bone marrow, lymph nodes, Peyer's parches, thymus and blood no significant PFC activity was found at any time after immunization. PFC-assay was done on pooled spleens. Each group consisted of at least 4 mice. 
The relatively low adoptive PFC response evoked by cells from mice primed with $100 \mu \mathrm{g}$ LPS i.v. (Fig. 6) is temporary. This was shown by transferring spleen cells, bone marrow cells and thymus cells from such mice 6 months after priming. At that time adoptive PFC responses were much higher than after 3 months (Table 2). Apparently high doses LPS i.v. result initially in a smaller number of B memory cells than do moderate doses of LPS. Hanna and Peters (1971) reported similar results for the appearance of $B$ memory cells in the spleen after immunization with SRBC. These authors ascribe the small numbers of $B$ memory cells after high doses of antigen to an exhaustion of this cell population, due to maturation of newly formed B memory cells into antibodyforming cells.

\section{DISCUSSION}

After primary immunization of rabbits with the thymus-independent antigen

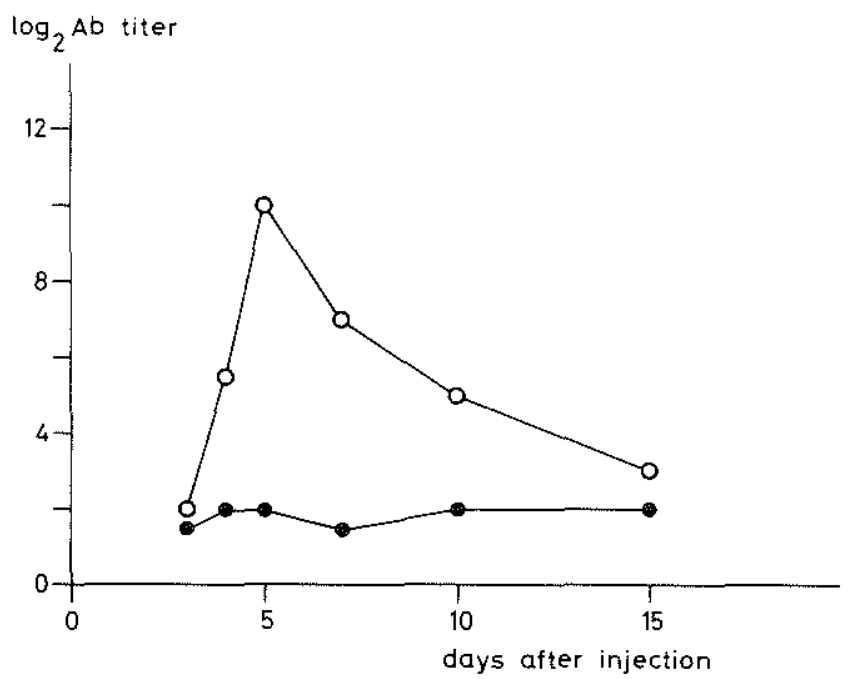

Fig. 3. Agglutinating antibody titres in the sera of mice shamsplenectomized (O) or splenectomized (1) I month before immunization with $0.1 \mu \mathrm{g}$ LPS $\mathrm{i} . \mathrm{v}$. The anti-LPS antibodies were 2-ME sensitive. 


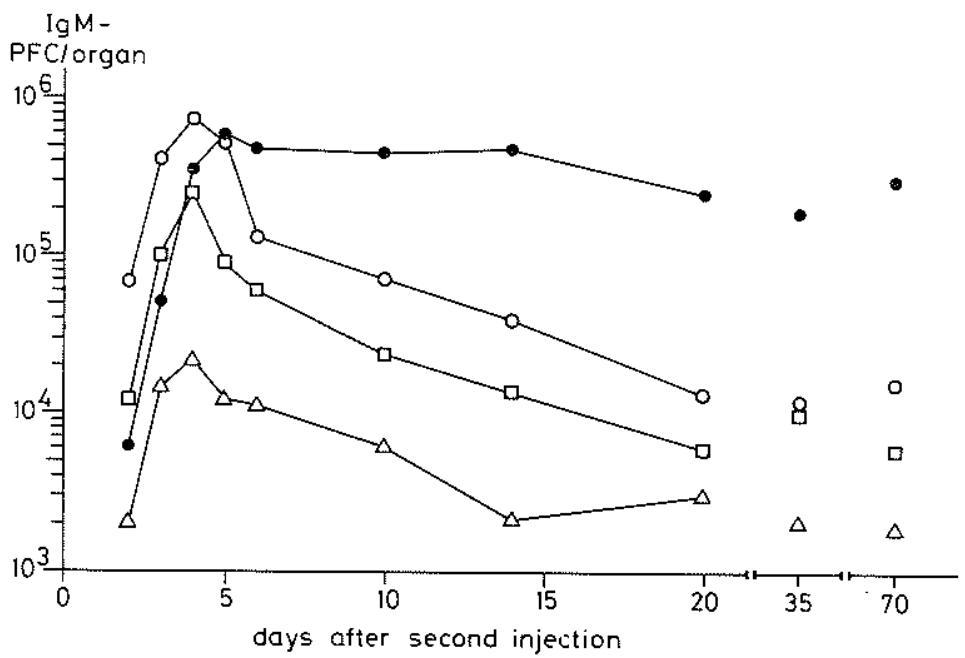

Fig. 4. Number of PFC in mouse spleen and bone marrow after two injections of LPS. Mice were primed with $1 \mu \mathrm{g}$ LPS $\mathrm{i} . \mathrm{v}$. and boosted with either 10 (O, spleen; bone marrow), 0.1 ( $\square$, spleen) or 0.001 ( $\Delta$, spleen) $\mu \mathrm{g}$ LPS i.v. 3 months later. After boosting with $10 \mu \mathrm{g}$ LPS i.v. PFC activity was found not only in spleen and bone marrow, but also in mesenteric lymph node, peripheral lymph nodes, Peyer's patches, thymus and blood (see Fig. 5). After boosting with 0.1 and $0.001 \mu \mathrm{g}$ LPS i.v. no significant PFC activity was found in other lymphoid organs than spleen.

Brucella, bone marrow cells of these animals cultured in vitro were found to release specific antibodies (Thorbecke et al., 1961). As far as antibody formation in vivo to thymus-independent antigens has been studied by means of the plaque xssay, most frequently PFC activity has been determined in spleen and lymph nodes. Only a few authors have studied the bone marrow as a source of PFC (Landy, Sanderson and Jackson, 1965; Baker, Stashak, Amsbaugh and Prescott, 1971). Landy et al. (1965) found small but significant numbers of PFC in the bone marrow of rabbits after primary immunization with Salmonella enteritidis polysaccharide. On the other hand Baker et al. (1971) could not detect any PFC activity in mouse bone marrow during the primary response to an optimal dose of type III pneumococcal polysaccharide (SIII). 


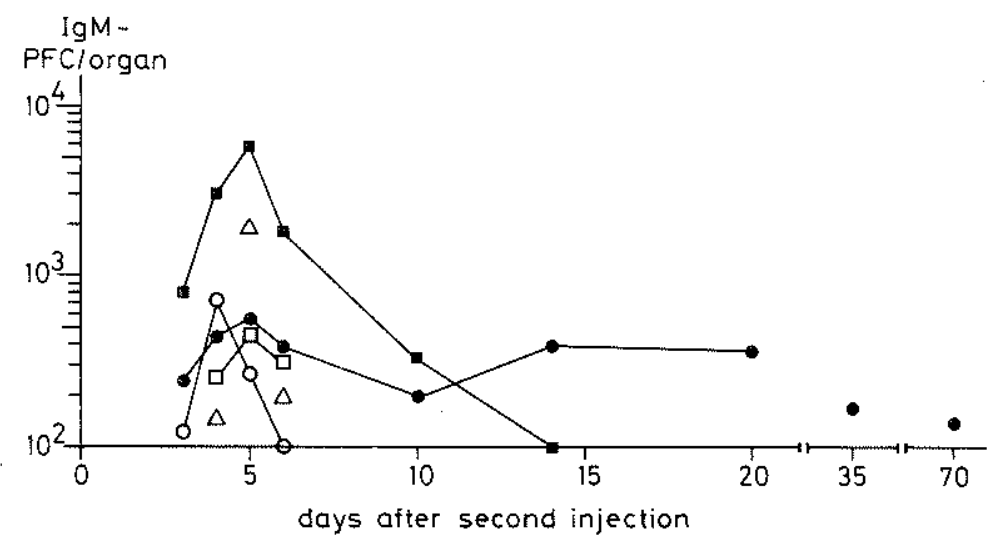

Fig. 5. Number of PFC in mouse mesenteric lymph node ( $\square$ ), peripheral lymph nodes (O), Peyer's parches ( $\square$ ), thymus (O), and blood ( $\boldsymbol{\Delta}$ ) after two injections of LPS. Mice were primed with $1 \mathrm{\mu g}$ LPS i.v. and boosted with $10 \mu \mathrm{g}$ LPS i.v. three months later. The organs were obtained from the same mice used to determine PFC activity in spleen and bone marrow (Fig. 4).

The results presented in this paper show that mouse bone marrow can exhibit a clear PFC activity to the thymus-independent antigen E. coli LPS, both during the primary (Fig. 1) and the secondary response (Fig. 4). In previous papers of this series (Benner et al., 1974a; 1974c; 1975) it has been shown that mouse bone marrow can contain large numbers of PFC to the thymus-dependent SRBC antigens, however, only during the secondary, and not during the primary response. Specific memory cells are probably required for the appearance of anti-SRBC PFC in the bone marrow during the secondary response (Benner et al., 1974b; 1975). Splenectomy experiments (Benner et al., 1974a; Benner and van Oudenaren, to be published) provided evidence for the in situ differentiation of non-antibody-producing cells into anti-SRBC and anti-LPS antibody forming cells in mouse bone marrow. The most tempting explanation why anti-SRBC PFC activity in the bone marrow is a memorydependent phenomenon, in contrast to anti-LPS bone marrow PFC activity, is related to the difference in thymic dependency between these two antigens. 
While after immunization with LPS B cells which are normally present in mouse bone marrow might differentiate without $T$ cell help into PFC in situ, SRBCspecific $B$ cells are unable to do so because they need the presence of $T$ memory cells.

It is notable that anti-LPS PFC responses in the bone marrow appear only after high doses of antigen. This observation and the absence of PFC activity in the bone marrow after i.p. immunization with an optimal dose of SIII (Baker et al., 1971) suggest that antibody formation to these thymus-independent antigens in the bone marrow is not only dependent on the presence of the appropriate B cells. In vitro experiments suggest that macrophages are involved

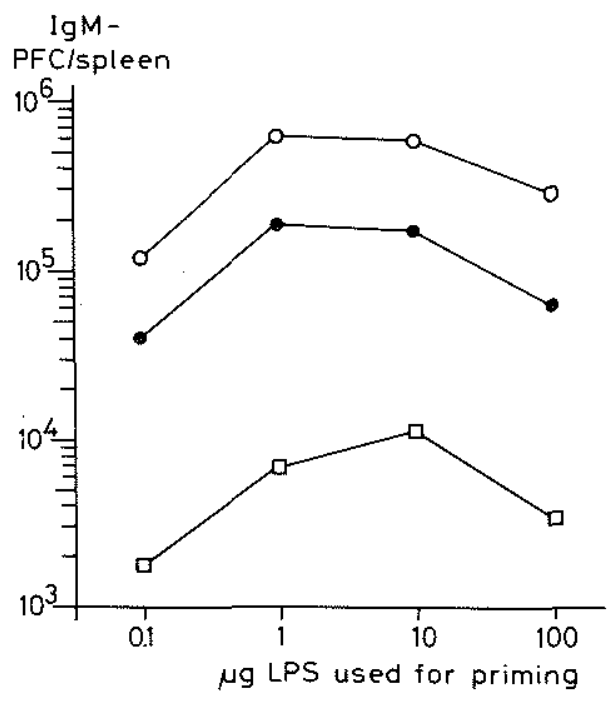

Fig. 6. Adoptive PFC response of spleen, bone marrow and thymus cells 3 months after priming with various doses LPS i.v. (O) Spleen cells, (-), bone marrow cells and ( $\square$ ) thymus cells. Viable nucleated cells $\left(2 \times 10^{7}\right)$ were transferred to lethally irradiated syngeneic mice together with $5 \mu \mathrm{g}$ LPS. Each group consisted of 5 recipient mice. PFCassay was done on pooled spleens 7 days after cell transfer. Transferred spleen cells, bone cells and thymus cells from non-immune mice evoked 49,500, 11,250 and 175 PFC respectively. 
in antibody formation to LPS (Bona, Robineaux, Heuclin and Astesana, 1973) and SIII (Aaskov and Halliday, 1971). The appearance of anti-LPS PFC in the bone marrow after immunization with 1 or $10 \mu \mathrm{g}$ LPS (Fig. 1 and 4) might therefore be due to interference by LPS with the reticuloendothelial system (RES). Benacerraf and Sebestyen (1957) showed that doses of $10 \mu \mathrm{g}$ LPS i.v. cause a transitory depression of the phagocytic activity of the RES. Within one day this depression is followed by a period of increased phagocytic acti-

\section{$\underline{\text { TABLE } 2}$}

Adoptive PFC Response by Spleen, Bone Marrow and Thymus Cells 3 and 6 Months after Priming with $100 \mu g$ LPS i.v.

\begin{tabular}{lrr}
\hline \multirow{2}{*}{ Cells transferred from ${ }^{a}$} & \multicolumn{2}{c}{ PFC/recipient spleen } \\
\cline { 2 - 3 } & 3 months & 6 months \\
\hline Spleen & 272,900 & 872,500 \\
Bone marrow & 58,100 & 179,250 \\
Thymus & 3,200 & 8,025
\end{tabular}

${ }^{a}$ Viable nucleated cells $\left(2 \times 10^{7}\right)$ and $5 \mu \mathrm{gg}$ LPS were transferred to lethally irradiated syngeneic mice.

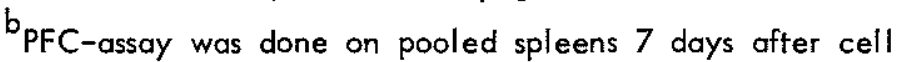
transfer. Each group consisted of 5 recipient mice. Figures from a representative experiment.

vity. When the presentation of antigen to lymphocytes in the bone marrow is the limiting factor for initiation of an anti-LPS PFC response in situ, stimulation of the phagocytic activity of the RES probably accounts for the appearance of PFC in the bone marrow after immunization with relatively high doses of LPS.

It is of interest to compare the minimal threshold antigen dose of LPS and 
SRBC in spleen and bone marrow. The threshold dose of LPS for the bone marrow was about a thousand times higher than for the spleen. Such a great difference in the threshold antigen dose for spleen and bone marrow was not appearent during the secondary response to SRBC (Benner et al., 1974c). Several causes may account for this difference. In our opinion the most probable ones are related to the presentation of the antigen to lymphocytes in these organs with an anatomically so different structure:

(1) In contrast to SRBC, LPS is a polymeric antigen and is composed of much smaller particles (Shands, 1971). Therefore red blood cells might be more susceptible to antigen-processing mechanisms in the bone marrow than LPS. (2) LPS only evokes the production of IgM-antibodies; SRBC, however, can also evoke the formation of $\mathrm{lg} G$-antibodies which have a much longer halflife and are better opsonins than IgM (Spiegelberg, 1974). At the moment of the second injection of SRBC opsonic antibodies from the primary response cause an optimal antigen-processing in the bone marrow. On the other hand, when mice receive a primary injection of LPS or a second one 3 months later, little or no specific IgM is present. Consequently antigen-processing within the bone marrow could be deficient.

In some respects there is a striking similarity between the shape of the spleen and bone marrow PFC curves during the secondary response to SRBC (Benner et al., 1974a; 1974c; 1975) and the response to $10 \mu \mathrm{g}$ LPS. For both antigens the bone marrow PFC response is characterized by (1) a delayed appearance of PFC as compared with the spleen, and (2) a much higher PFC activity than in all other lymphoid organs together during the second phase of the response. The underlying regulating mechanisms of these phenomena are unclear. The delay of appearance of PFC in the bone marrow might be related to differences in antigen processing between spleen and bone marrow. Alternatively this delayed appearance of PFC might be due to a time-consuming migration of cells involved in the bone marrow PFC response into this organ during the first phase of the response. Although in previous papers (Benner et al., 1974a; 1975) migration of PFC from peripheral lymphoid organs into 
the bone marrow could be excluded as the underlying cause for PFC activity in the bone marrow, the possibility of immigration in the bone marrow of cells triggered to give a PFC response has to be considered. The high bone marrow PFC activity during the second phase of the response is possibly due to one or more local factors which enhance the differentiation into PFC within the bone marrow. Recently it was reported that bone marrow cells can synthesize a humoral factor which enhances the PFC response in cultures of lymph node cells obtained from immune donors at the peak of the productive phase of antibody formation (Petrov, Mikhajlova, Stepanenko and Zakharova, 1975). This factor might account for the high PFC activity observed in the bone marrow during the second phase of the response.

The appearance of B memory cells in the thymus after i.v. immunization with LPS (Fig. 6) is consistent with previous experiments with SRBC as antigen (Jehn and Karlin, 1971; Benner, Meima and van der Meulen, 1974d). The presence of $B$ memory cells in the thymus coincides with the capacity of this organ to exhibit PFC activity upon subsequent stimulation with the antigen used for priming. This suggests that the appearance of PFC in the thymus during the secondary response is due to an in situ differentiation of $B$ memory cells into PFC. Thymic PFC responses can only be evoked by high doses of antigen (Fig. 5; Benner et al., 1974c) probably because antigens scarcely enter the thymus tissue (Kater, 1970).

\section{ACKNOWLEDGMENTS}

We are very indebted to Professor Dr. O. Vos, Dr. W. Hijmans, Dr. O.B. Zaalberg and Dr. G.H. Blijham for their discussion of the manuscript.

This investigation was supported by the Netherlands Foundation for Medical Research (FUNGO).

\section{REFERENCES}

Aaskov, J.G. and Halliday, W.J. (1971). 'Requirements for lymphocyte-macro- 
phage interaction in the response of mouse spleen cultures to pneumococcal polysaccharide.' Cell. Immunol., 2, 335 .

Andersson, B. and Blomgren, H. (1971). 'Evidence for thymus-independent humoral antibody production in mice against polyvinylpyrrolidone and E. coli lipopolysaccharide.' Cell. Immunol., 2, 411.

Baker, P.J., Stashak, P.W., Amsbaugh, D.F. and Prescott, B. (1971). 'Characterization of the antibody response to type III pneumococcal polysaccharide at the cellular level. 1. Dose-response studies and the effect of prior immunization on the magnitude of the antibody response.' Immunology, 20, 469.

Benacerraf, B. and Sebestyen, M.M. (1957). 'Effect of bacterial endotoxins on the reticuloendothelial system.' Fed. Proc., 16, 860.

Benner, R., Meima, F., van der Meulen, G.M. and van Muiswinkel, W.B. (1974a). 'Antibody formation in mouse bone marrow. I. Evidence for the development of plaque-forming cells in situ.' Immunology, 26, 247.

Benner, R., Meima, F. and van der Meulen, G.M. (1974b). 'Antibody formation in mouse bone marrow. II. Evidence for a memory-dependent phenomenon.' Cell. Immunol., 13, 95.

Benner, R., Meima, F., van der Meulen, G.M. and van Ewijk, W. (1974c). 'Antibody formation in mouse bone marrow. III. Effects of route of priming and antigen dose.' Immunology, 27, 747.

Benner, R., Meima, F. and van der Meulen, G.M. (1974d). 'B memory cells in the thymus: resistance to corticosteroid treatment in vivo and to anti theta treatment in vitro.' Cell. Immunol., 14, 151. 
Benner, R. and van Oudenaren, A. (1975). 'Antibody formation in mouse bone marrow. IV. The influence of splenectomy on the bone marrow plaque-forming cell response to sheep red blood cells.' Cell. Immunol., 19, 167, 1975.

Bona, C., Robineaux, R., Anteunis, A., Heuclin, C. and Astesano, A. (1973). 'Transfer of antigen from macrophages to lymphocytes. II. Immunological significance of the transfer of lipopolysaccharide.' Immunology, 24, 831.

Boyum, A. (1968). 'Isolation of mononuclear cells and granulocytes from human blood.' Scan. J. Clin. Lab. Invest., suppl. 97, 77.

Chervenick, P.A., Boggs, D.R., Marsh, J.C., Cartwright, G.E. and Wintrobe, M.M. (1968). 'Quantitative studies of blood and bone marrow neutrophils in normal mice.' Amer. J. Physiol., 215, 353.

Cunningham, A.J. and Szenberg, A. (1968). 'Further improvements in the plaque technique for detecting single antibody-forming cells.' Immunology, 14, 599.

Hanna, M.G. and Peters, L.C. (1971). 'Requirement for continuous antigenic stimulation in the development and differentiation of antibody-forming cells: effect of antigen dose.' Immunology, 20, 707.

Jehn, U.W. and Karlin, L. (1971). 'Independent action of thymus and bone marrow cells during the secondary response of direct plaque-forming cells.' J. Immunol., 106, 946.

Kater, L. (1970). 'Morphological and dynamic aspects of the thymus.' Thesis, Utrecht, The Netherlands.

Langevoort, H.L., Asofsky, R.M., Jacobson, E.B., de Vries, T. and Thorbecke, 
G.J. (1963). 'Gamma globulin and antibody formation in vitro. II. Parallel observations on histologic changes and on antibody formation in the white and red pulp of the rabbit spleen during the primary response, with special reference to the effect of endotoxin.' J. Immunol., 90, 60 .

Landy, M., Sanderson, R.P. and Jackson, A.L. (1965). 'Humoral and cellular aspects of the immune response to the somatic antigen of Salmonella enteritidis.' J. exp. Med., $\underline{122} 483$.

Mishell, R.I. and Dutton, R.W. (1967). 'Immunization of dissociated spleen cell cultures from normal mice.' J. exp. Med., 134, 423.

Moller, G. and Michael, G. (1971). 'Frequency of antigen-sensitive cells to thymus-independent antigens.' Cell. Immunol., 2, 309.

Petrov, R.V., Mikhajlova, A.A., Stepanenko, R.N. and Zakharova, L.A. (1975). 'Cell interactions in the immune response: effect of humoral factor released from bone marrow cells on the quantity of mature antibody producers in culture of immune lymph node cells.' Cell. Immunol., 17, 342.

Shands, J.W. (1971). 'The physical structure of bacterial lipopolysaccharides.' Microbial Toxins (Ed. by G. Weinbaum, S. Kadis and S.J. Ail), volume 4, p. 127, Academic Press, New York.

Spiegelberg, H.L. (1974). 'Biological activities of immunoglobulins of different classes and subclasses.' Advances in Immunology (Ed. by F.J. Dixon and H.G. Kunkel), volume 19, p. 259, Academic Press, New York.

Thorbecke, G.J., Asofsky, R., Hochwald, G.M. and Siskind, G.W. (1961). 'Antibody production in vitro by spleen and bone marrow at various days 
after injection of antigen.' Fed. Proc., 20, 25.

Westphal, O., Lüderlitz, O. and Bister, F. (1952). 'Uber die Extraction von Bakterien mit Phenol-Wasser.' Naturforsch., Z 143. 